\title{
Why is the Vaccination Rate Low in India?*
}

First Version: January 2021

This Version: August 2021

\author{
Pramod Kumar Sur ${ }^{\dagger}$ \\ Asian Growth Research Institute (AGI) and Osaka University
}

\begin{abstract}
Why does the vaccination rate remain low, even in countries where long-established immunization programs exist, and vaccines are provided for free? We study this lower vaccination paradox in the context of India - which contributes to the largest pool of under-vaccinated children in the world and about one-third of all vaccine-preventable deaths globally. We explore the importance of historical events shaping current vaccination practices. Combining historical records with survey datasets, we examine the Indian government's forced sterilization policy implemented in 1976-77 and find that greater exposure to forced sterilization has had a large negative effect on the current vaccination completion rate. We explore the mechanism for this practice and find that institutional delivery and antenatal care are low in states where policy exposure was high. Finally, we examine the consequence of lower vaccination, suggesting that child mortality is currently high in states with greater sterilization exposure. Together, the evidence suggests that government policies implemented in the past could have persistent impacts on adverse demand for healthseeking behavior, even if the burden is exceedingly high.
\end{abstract}

Keywords: Vaccination, immunization, family planning, forced sterilization, institutional delivery, antenatal care, child mortality, persistence

JEL Classification: N01, I12, I18, O53, J13, Z1

\footnotetext{
*I thank Nathan Nunn, Kensuke Teshima, Chikako Yamauchi, and numerous seminar and conference participants for excellent feedbacks. I am grateful for financial support from the Japan Society for the Promotion of Science (No. $21 \mathrm{~K} 13307)$.

† Email: pramodsur@gmail.com
} 
medRxiv preprint doi: https://doi.org/10.1101/2021.01.21.21250216; this version posted August 11, 2021. The copyright holder for this preprint (which was not certified by peer review) is the author/funder, who has granted medRxiv a license to display the preprint in perpetuity. It is made available under a CC-BY-NC-ND 4.0 International license .

\section{Introduction}

Vaccines are among the greatest advances in global health and development, saving millions of lives each year (UNICEF). ${ }^{1}$ It is also one of the safest methods to protect children from lifethreatening diseases. However, despite having access to vaccines for more than 20 life-threatening diseases, and many vaccines are available for free, about 20 million children still do not receive sufficient vaccines each year (WHO 2020).

India contributes to the largest pool of under-vaccinated children in the world (CDC 2013). Additionally, about one in three child deaths due to vaccine-preventable diseases globally occur in India alone (Black et al. 2010). Moreover, India has one of the lowest vaccination rates in the world. ${ }^{2}$ For example, India's vaccination rate is even lower than that of its nearest neighbors Bangladesh, Bhutan, and Nepal, all of which have a lower GDP than India. ${ }^{3}$ The statistics on India's lower vaccination rate are particularly puzzling because India already has had an established immunization program since 1978, and vaccination services are provided for free. ${ }^{4}$ So why is the vaccination rate low in India?

The main objective of this paper is to 1) understand the factors behind the paradox of India's lower vaccination rate, 2) examine plausible mechanisms for such practices, 3) explore the reasons for the mechanisms, and finally, 4) access the present-day consequence. ${ }^{5}$ Addressing these issues is not only fundamental from a scientific and academic standpoint but also essential in terms of ethical reasons and policy aspects for the following reasons. First, the cost of poor vaccination in India is extremely high. For example, according to India's most recent estimates in 2015, more than 300,000 children died due to vaccine-preventable diseases - constituting about two-thirds of all types of deaths in children (Liu et al. 2016). Second, considering that most vaccines are administered for communicable diseases, there is a greater need to improve vaccination uptake to achieve herd immunity. Thus, an increasing number of efforts are being undertaken recently to

\footnotetext{
${ }^{1} \mathrm{https}: / /$ www.unicef.org/immunization

${ }^{2}$ According to India's National Family and Health Survey 2015-16 (NFHS-4), only about 43\% of children between 12 and 23 months of age are fully immunized in 2015-16. Similarly, the coverage rate for the third dose of diphtheria-pertussis-tetanus (DPT-3) vaccine, a frequently used proxy for the success of a country's vaccination program, is $78 \%$, well below the global average of $86 \%$.

${ }^{3}$ UNICEF estimates.

https://www.unicef.org/rosa/media/6901/file/South_Asia_Immunization_Regional_Snapshot_2018.pdf

${ }^{4}$ Additionally, it is home to the largest vaccine maker in the world — Serum Institute of India. See, https://www.seruminstitute.com/about_us.php

${ }^{5}$ India did not have any adult vaccination program until the recent COVID-19 vaccination program. Therefore, we primarily focus on the lower vaccination paradox among children.
} 
medRxiv preprint doi: https://doi.org/10.1101/2021.01.21.21250216; this version posted August 11, 2021. The copyright holder for this preprint (which was not certified by peer review) is the author/funder, who has granted medRxiv a license to display the preprint in perpetuity. It is made available under a CC-BY-NC-ND 4.0 International license .

improve India's vaccination rate through various government programs. ${ }^{6}$ However, little scientific evidence exists on the causal pathways through which individual and social characteristics influence decision-making for vaccinations (Francis et al. 2018). Finally, considering the current state of the coronavirus disease 2019 (COVID-19) pandemic and the need for universal vaccination, policy-makers and practitioners need to understand the factors affecting India's vaccination practice to carve out a pragmatic policy and maximize the uptake of new vaccines.

In this paper, we provide the first empirical investigation of the importance of a policy implemented by the government in the past in shaping current vaccination practices in India. In particular, we examine whether the aggressive family planning program, under which the forced sterilization policy was implemented during the emergency rule in India in the 1970s, could partly explain the lower vaccination rate today.

India went through a brief period of autocratic rule between June 1975 and March 1977 under prime minister Indira Gandhi. ${ }^{7}$ During this period, she proclaimed a national emergency, under which the Indian constitution was suspended for a wide range of civil liberties. A distinctive feature synonymous with this period that affected the general population was the aggressive family planning policy through forced sterilization (hereafter, forced sterilization policy) in the latter part of the emergency period. After about a year of emergency rule, in April 1976, the Ministry of Health and Family Planning introduced a National Population Policy (NPP) under which a family planning program was aggressively undertaken mostly through sterilizing individuals. Between April 1976 and March 1977, about 8.3 million sterilizations were performed, more than three times the number in the previous year (see figure 1). The aggressive nature of the program led to serious consequences, including medical complications, death, and sterilization of ineligible individuals. Additionally, historical records, court rulings, and anecdotal evidence suggest that incentives and disincentives were provided, coercion was enforced, and public officials delivered disinformation to motivate individuals to undergo sterilization during this period (Shah Commission of Inquiry 1978; Panandiker, Bishnoi, and Sharma 1978).

We hypothesize that the forced sterilization policy undertaken during the emergency rule period may have had an unintended effect on India's vaccination practice. There are reasons to expect

\footnotetext{
${ }^{6}$ Such programs include Mission Indradhanush (in 2014), Intensified Mission Indradhanush (IMI) (in 2017), IMI 2.0 (in 2019), and IMI 3.0 (in 2021).

${ }^{7}$ The autocratic rule (emergency) officially ended in March 1977. However, it was substantially relaxed in January 1977.
} 
medRxiv preprint doi: https://doi.org/10.1101/2021.01.21.21250216; this version posted August 11, 2021. The copyright holder for this preprint (which was not certified by peer review) is the author/funder, who has granted medRxiv a license to display the preprint in perpetuity.

It is made available under a CC-BY-NC-ND 4.0 International license .

that the policy could have had unintended consequences on vaccination practice. First, the same organization (Ministry of Health and Family Planning) that implemented the highly controversial forced sterilization policy introduced the first immunization program a year later in $1978 .{ }^{8}$ Second, the health care staffs (e.g., community health workers, auxiliary nurse midwives) that coerced and disinformed individuals to get sterilized during the emergency period are the ones that also engage in advising and motivating parents to vaccinate their children. Finally and importantly, anecdotal evidence suggests that one of the main challenges for the recent vaccination campaigns-IMI in 2017 and the present COVID-19 vaccination - is concern about the circulation of disinformation about vaccines, rumors about adverse effects, and conspiracy theories, including vaccines causing sterilization, impotent, and infertility (Gurnani et al. 2018; BBC 2021; Hindustan Times 2021; India Today 2021). ${ }^{9}$ Thus, we examine the legacy of the forced sterilization policy on India's current vaccination practice.

To measure exposure to the forced sterilization policy, we digitized the historical yearbooks published by the Ministry of Health and Family Planning, Department of Family Planning, Government of India. These yearbooks report statistics on family planning programs performed between April and March every year at the state and union territory (UT) levels. ${ }^{10}$ Our primary measure of exposure to the forced sterilization policy is the number of excess sterilizations performed between April 1976 and March 1977 (after the introduction of the NPP), normalized by its performance in the previous year. We also corroborate our primary measure of exposure to the forced sterilization policy with different sterilization measures, including the total number of sterilizations performed in 1976-77, the excess number of sterilizations performed in 1976-77, total and excess sterilizations in a natural logarithm scale, and an alternative measure of exposure to sterilization measured by vasectomies, which constituted the majority of the sterilizations performed during this period.

Our primary outcome is vaccination completion rates. We examine vaccination completion rates using data from India's national representative NFHS-4. The NFHS-4 reports a total of 13 vaccines

\footnotetext{
${ }^{8}$ The first immunization program was introduced in India as Expanded Program on Immunization (EPI). The EPI was renamed to Universal Immunization Program (UIP) about a decade later, in 1985, which currently promotes the vaccination of children.

${ }^{9}$ Also, see (Vardhan 2021) — The Health minister of India — refuting a series of claims regarding the vaccine rumors and disinformation on Twitter in a series of tweets.

${ }^{10}$ Hereafter, we refer to 'states and union territories' in India as 'states' for simplicity.
} 
medRxiv preprint doi: https://doi.org/10.1101/2021.01.21.21250216; this version posted August 11, 2021. The copyright holder for this preprint (which was not certified by peer review) is the author/funder, who has granted medRxiv a license to display the preprint in perpetuity. It is made available under a CC-BY-NC-ND 4.0 International license .

for children under five. ${ }^{11}$ It categorizes these vaccines into three groups. We construct vaccination indexes that measure the share of completed vaccinations in each category for children under the age of 5 years. ${ }^{12}$ We find that higher exposure to the forced sterilization policy is associated with lower vaccination completion rates on all vaccination index measures. Our results are robust to a variety of controls, consideration of specific cohorts of children, and a number of alternative measures of exposure to the forced sterilization policy.

After presenting evidence that the forced sterilization policy has a negative association with India's current vaccination completion rate, we next turn to the task of addressing concerns over reverse causality and omitted variable bias using an instrumental variable (IV) estimation approach. Reverse causality will arise if the forced sterilization policy is strategically targeted towards places or regions where the propensity to vaccinate is low. Our second concern is the issue of omitted variable bias, which would arise if some other variables were jointly determining exposure to the forced sterilization policy and the vaccination rate that we do not account for in our estimation.

We construct an instrument for exposure to the sterilization policy based on the unique history of the emergency period that the sterilization was aggressively undertaken because of the active role played by Sanjay Gandhi — the younger son of the prime minister (Gwatkin 1979; Vicziany 1982; Chandra 2017; Indian National Congress 2011; Nayar 2013; Williams 2014). In fact, family planning was an integral part of his self-declared five-point program implemented during this period. Although Mr. Gandhi did not hold any formal position in government, he and his colleagues in New Delhi continuously influenced regional political leaders, particularly in the states adjacent to the national capital over which they had an influence (Shah Commission of Inquiry 1978). As a result, northern parts of India, especially adjacent states to New Delhi, were later popularly known as the "vasectomy belt" because of the large number of (male) sterilizations performed during this period. Gwatkin (1979) observes that distance from New Delhi to state capitals - a proxy measure for Mr. Gandhi's influence- which was previously irrelevant, emerged as an important determinant of excess sterilization performance during this period and was itself capable of explaining two-thirds of the variation in performance among the states.

\footnotetext{
11 The reported vaccines in NFHS-4 are BCG, Hepatitis-B 0, Hepatitis-B 1, Hepatitis-B 2, Hepatitis-B 3, DPT 1, DPT 2 DPT 3, Polio 0, Polio 1, Polio 2, Polio 3, and Measles. We exclude Vitamin A supplements reported in the survey since supplements are not a vaccine.

12 The vaccination indexes are basic vaccination (eight vaccines), age-appropriate vaccination (12 vaccines), and all vaccination (13 vaccines).
} 
medRxiv preprint doi: https://doi.org/10.1101/2021.01.21.21250216; this version posted August 11, 2021. The copyright holder for this preprint (which was not certified by peer review) is the author/funder, who has granted medRxiv a license to display the preprint in perpetuity.

It is made available under a CC-BY-NC-ND 4.0 International license .

Considering these anecdotal evidences and Gwatkin's observation, we use the distance from New Delhi to state capitals as an instrument to capture the variation in exposure to the forced sterilization policy.

The IV estimates also suggest that the forced sterilization policy has had a significant negative effect on the vaccination completion rate in India. Not only are the negative coefficient estimates statistically significant, but they are also economically meaningful. Our IV estimates indicate that an average increase in excess sterilization - from zero to about 3.5 times- decreases the completion of all vaccinations by about 8.1 percentage points. This is relative to a sample mean of 32.1 percent for our sample as a whole. It suggests that the forced sterilization policy has a sizable effect on India's current vaccination completion rate.

A potential concern could be that our instrument is not exogenous. To address this concern, we perform two falsification exercises. In our first falsification exercise, we formally test Gwatkin's (1979) insight. Because Mr. Gandhi had no personal influence over sterilization before 1976, our instrumental variable —if exogenous - should have no predictive power on sterilization performance before 1976. ${ }^{13}$ That is exactly what we find. We perform a placebo IV test and find that the distance from New Delhi to state capitals has no predictive power for excess sterilization performed in 1975-76 in the first stage or the vaccination rate in the second stage.

In the second falsification exercise, we examine whether or not the sterilization policy's forceful nature is only associated with our instrument. To explore this, we consider female sterilization, or tubectomy, which was not the main focus during India's forced sterilization period. The main reason for not focusing on tubectomy was that it constituted major abdominal surgery-which needs a longer period of hospitalization for about four days to a week. However, vasectomy is a relatively quick procedure, and recipients can be discharged on the same day of the operation. Because sterilization was mostly performed in temporary camps during this period, vasectomy was preferred over tubectomy (Gwatkin 1979; Shah Commission of Inquiry 1978; Scott 2017). We test this narrative and find that our instrumental variable has no predictive power for excess female sterilizations performed during 1976-77 in the first stage and the vaccination rate in the second stage. These falsification exercises provide suggestive evidence that our instrumental variable is plausibly exogenous.

\footnotetext{
${ }^{13}$ Alternatively, this is also, in a way, to test whether state-level existing health policies or health infrastructures are related to our instrument.
} 
medRxiv preprint doi: https://doi.org/10.1101/2021.01.21.21250216; this version posted August 11, 2021. The copyright holder for this preprint (which was not certified by peer review) is the author/funder, who has granted medRxiv a license to display the preprint in perpetuity. It is made available under a CC-BY-NC-ND 4.0 International license .

We then turn to examine the heterogeneous effect of the forced sterilization policy on the current vaccination rate. We explore each vaccine separately to obtain some insights into whether the lower vaccination rate we observe differs for some specific vaccines. We find that higher exposure to the forced sterilization policy has the largest negative and statistically significant effect on vaccines given at birth (i.e., Polio 0 and Hepatitis 0 ). Second, we find some evidence suggesting that the vaccination rate declines with higher doses for vaccines administered multiple times, such as hepatitis, DPT, and Polio.

Next, we explore the plausible channels through which the forced sterilization policy affects India's current vaccination rate. First, considering the results from our heterogeneous analysis, we explore whether the place of delivery is a possible channel. Place of delivery - at home or in an institution such as a health care facility - is an important determinant for vaccination because some vaccines are given immediately after birth. In our sample, about $20 \%$ of children are born at home (noninstitutional delivery). We find that exposure to the forced sterilization policy has a large, positive, and significant effect on noninstitutional delivery.

Digging a little further, we also check the reasons for noninstitutional delivery. The NFHS-4 asks mothers for reasons for not delivering in a health care facility. The average effect size and coefficients of individual answers suggest that exposure to the forced sterilization policy on supply-side constraints are minimum, sometimes negative, and statistically insignificant. ${ }^{14}$ However, the effects on demand-side constraints - such as not customary, not necessary, not allowed by husband or family, and no trust in health care facilities/ poor-quality service-are positive, large, and statistically significant. These results suggest that demand-side factors are important mechanisms.

We also test the effect of a plausible indirect channel of information provision on vaccination behavior. Several studies have shown that information provision is essential to generate take-up rates in health-seeking behavior (for a review, see Dupas and Miguel, 2017). We test for this channel because one of the main challenges of India's recent vaccination campaign was concern about the circulation of disinformation, rumors, and conspiracy theories, including vaccines causing sterilizations, impotency, and infertility. In such an environment, the provision of reliable and accurate information can help increase the vaccination rate. We study one such platform:

\footnotetext{
14 The supply-side factors include higher cost, the facility not being open, the facility being far away with no transportation, and no female provider.
} 
medRxiv preprint doi: https://doi.org/10.1101/2021.01.21.21250216; this version posted August 11, 2021. The copyright holder for this preprint (which was not certified by peer review) is the author/funder, who has granted medRxiv a license to display the preprint in perpetuity.

It is made available under a CC-BY-NC-ND 4.0 International license .

antenatal care (ANC). ANC is essential to reduce the health risks for mothers and their babies during pregnancy and can be an important source of reliable and accurate information regarding a child's future health-seeking behavior, such as vaccination practice. We find that exposure to the forced sterilization policy has a large, negative, and significant effect on visiting a health care center for $\mathrm{ANC}$ and the number of visits conditional on receiving ANC. These results suggest that a lack of reliable and accurate information provision may also be an important channel.

Finally, we examine the relevance of historical forced sterilization policy on present-day consequences of lower vaccination measured by child mortality. ${ }^{15} \mathrm{We}$ find that child mortality is currently high in states with greater sterilization exposure. The effect size is quite large. An average increase in excess sterilization increases the probability of a child under the age of five not alive by about 2.7 percentage points, relative to a sample mean of $4.5 \%$. These results highlight the importance of history for understanding the present-day health outcomes, and more broadly, how historical events affect the demand for health-seeking behavior even if the burden is exceedingly high.

In addition to the historical literature discussed previously, our paper is related to several diverse literatures in economics. First, it contributes to the literature on understanding the factors associated with India's lower vaccination paradox. Recent studies on India suggest that the lower vaccination rate is explained by child's individual-level characteristics, including gender, age, birth order, and other household factors such as family size, number of children in the household, household wealth, place of residence, caste, religion, and maternal education (Francis et al. 2018; Ghosh and Laxminarayan 2017; Shrivastwa et al. 2015; Srivastava, Fledderjohann, and Upadhyay 2020). However, such characteristics cannot explain all the differences (see Figure A1 in the Appendix). For example, according to the NFHS-4 estimates, the vaccination rate is still relatively low among male children (43.1\%), for a child with the lowest birth order (47.8\%), urban residents (46\%), mothers with 12 or more years of education (51.3\%), Hindu households $(44.2 \%)$, forward castes $(42.9 \%)$, and households in the highest wealth quintile $(52.9 \%) .{ }^{16}$ Furthermore, recent studies highlighted that the absolute demand for vaccination in India is low even when there is a

\footnotetext{
${ }^{15}$ We test child mortality as the consequence of lower vaccination because studies have shown that about two-thirds of all types of deaths in children in India are due to vaccine-preventable diseases (Liu et al. 2016).

16 These estimates are based on 12 reported vaccines (excluding Polio given at birth) for children between 12-23 months of age. Therefore, they are much higher than the general average estimates, such as children under the age of five.
} 
medRxiv preprint doi: https://doi.org/10.1101/2021.01.21.21250216; this version posted August 11, 2021. The copyright holder for this preprint (which was not certified by peer review) is the author/funder, who has granted medRxiv a license to display the preprint in perpetuity. It is made available under a CC-BY-NC-ND 4.0 International license .

reliable supply of free immunization services with incentives (Banerjee et al. 2010; Chernozhukov et al. 2020), and sometimes these incentives backfire (Chernozhukov et al. 2020). We build on this literature in three ways. First, we compile novel historical data and provide the first empirical investigation of the importance of historical events in shaping India's lower vaccination paradox. Second, we provide a causal pathway, the mechanisms, and the reasons for the mechanisms through which historical characteristics influence decision-making about childhood vaccinations. Third, we present the consequence of lower vaccination measured by child mortality.

This paper is also related to the broader literature on understanding the barriers associated with health-seeking behavior in developing countries (Dupas 2011). Recently, randomized experiments have been extensively used to examine both demand- and supply-side barriers to health care utilization (for a review, see Dupas and Miguel, 2017). We contribute to this literature on understanding the demand-side barriers to health-seeking behavior by considering historical intervention as a natural experiment. As demonstrated earlier, India is a typical case where the demand for health-seeking behavior such as vaccination is low, even if the burden is exceedingly high. We present evidence suggesting that historical policies implemented in the past could have a long-term and persistent effect on adverse demand for health-seeking behavior.

This work is also related to the literature on the unintended consequences of health interventions. Recent studies have found that the disclosure of information related to unethical medical intervention has had adverse effects on medical mistrust and health-seeking behavior, including immunization (Alsan and Wanamaker 2018; Martinez-Bravo and Stegmann 2021). Relatedly, Lowes and Montero (2021) find that historical medical campaigns during the colonization period in Africa have had a long-term impact on health outcomes and trust in medicine. We build on this work by presenting evidence on how a domestic policy implemented by the government in the past could have a long-term spillover effect on vaccination, institutional delivery, ANC, and child mortality in India.

Finally, this paper also contributes to the literature on understanding the importance of historical events on current development (Nunn 2009). This field has been studied extensively, beginning with the seminal work by Acemoglu, Johnson, and Robinson (2001) (for a review, see Nunn, 2014). We build on this literature in two ways. First, we demonstrate that a short-term policy-that lasted for less than a year-has had a large, negative, and significant long-term impact on later 
medRxiv preprint doi: https://doi.org/10.1101/2021.01.21.21250216; this version posted August 11, 2021. The copyright holder for this preprint (which was not certified by peer review) is the author/funder, who has granted medRxiv a license to display the preprint in perpetuity.

It is made available under a CC-BY-NC-ND 4.0 International license .

development outcomes measured by health care indicators. ${ }^{17}$ Second, we present evidence showing that historical events can affect subsequent policies implemented by the same organization or government agencies, even when the policies were well-intentioned. This has important implications, particularly for public policy, since several countries currently pursue evidence-based policy-making through experimentation. We empirically show that a policy failure could have spillover effects and affect subsequent policies in the long run.

The remainder of the paper is structured as follows. Section 2 provides a brief background to the emergency rule, the forced sterilization policy, and the immunization program in India. Section 3 describes the historical and contemporary data used in the empirical analysis. Section 4 presents the OLS and IV results. Section 5 examines the heterogeneous effect of the forced sterilization policy on vaccination. Section 6 presents a direct and an indirect mechanism. Section 7 explores the consequence, and section 8 concludes.

\section{Background}

\subsection{Emergency Rule and Forced Sterilization in India}

On June 25, 1975, Prime Minister Indira Gandhi proclaimed a national emergency in India. The exact reason for the proclamation of emergency is controversial. However, historians, sociologists, and political scientists agree that a combination of political and economic problems facing her and India could be the most likely factor. ${ }^{18}$

In 1971, Mrs. Gandhi won a major national election under a radical slogan of ending poverty (garibi hatao). However, food production was decreased in the succeeding years because of poor rainfall. Furthermore, the balance of payments was in turmoil because of a sharp rise in oil prices and the subsequent slump in export demand. Things became more complicated in June 1975, when Allahabad High Court found Mrs. Gandhi guilty of various corrupt election practices in the 1971 national election, jeopardizing her continuation as the prime minister. The court decision led to opposition protests and demands that Mrs. Gandhi resign. Instead of resigning, she seized the moment and proclaimed a national emergency, justifying the situation as a threat to India's internal stability (Hewitt 2007).

\footnotetext{
${ }^{17}$ In India's case, the government implemented the forced sterilization policy in April 1976 and ended it less than a year later, in January 1977.

${ }^{18}$ For a detailed overview of this period, see Dhar (2018) and Nayar (2013).
} 
medRxiv preprint doi: https://doi.org/10.1101/2021.01.21.21250216; this version posted August 11, 2021. The copyright holder for this preprint (which was not certified by peer review) is the author/funder, who has granted medRxiv a license to display the preprint in perpetuity.

It is made available under a CC-BY-NC-ND 4.0 International license .

The emergency rule allowed Mrs. Gandhi to suspend a wide range of civil liberties under the Indian constitution. Her government used this period to repress the opposition and institute censorship in the name of law and order. Thousands, including leading opposition leaders, were arrested, the press was censored, and public gatherings and strikes were declared illegal. With all the power in her hand, she undertook a series of new legislative and constitutional amendments to govern the country and extend the emergency period. Furthermore, she delayed parliamentary elections several times, indicating her intent to remain in power, an impression strengthened by (unofficially) elevating her younger son Sanjay to the position of apparent heir (Gwatkin 1979). However, in January 1977, Mrs. Gandhi unexpectedly called an election and released opposition leaders from jail, lifted press censorship, and permitted public meetings once again. The emergency period officially ended in March after the Indian National Congress party's defeat in the lower house of the Indian parliament election (Lok Sabha).

A distinguishing characteristic synonymous with this period was the aggressive family planning drive through forced sterilization. ${ }^{19}$ It started in April 1976, just over a year after the start of emergency rule. It began with the National Population Policy (NPP) for India introduced by the Ministry of Health and Family Planning to the parliament on April 17. The NPP's principal aim was to reduce the population growth rate by boosting the family planning program. The new policy incorporated a series of fundamental changes to reduce population growth. The legislation primarily included a substantial increase in monetary compensation for sterilization acceptors, encouragement for state-level incentives and disincentives for family planning, disenfranchisement of states that failed to control fertility rates by freezing their representation in parliament based on the 1971 census figures, allocation of central assistance to states according to family planning performance, and most controversially, the provisions for state governments to pass compulsory sterilization legislation (Singh 1976).

With the NPP's introduction, the central government authorized and endorsed various coercive measures for sterilization and, in extreme cases, the provision for compulsory sterilization. The central and state governments substantially increased the financial rewards for sterilization acceptors. Through a range of incentives and disincentives, they pressured their employees to get

\footnotetext{
${ }^{19}$ For a detailed overview of the family planning program during the emergency rule period, the complete reliance on sterilization only, and the forceful nature of the program see Panandiker, Bishnoi, and Sharma (1978), Shah Commission of Inquiry (1978), and Gwatkin (1979).
} 
medRxiv preprint doi: https://doi.org/10.1101/2021.01.21.21250216; this version posted August 11, 2021. The copyright holder for this preprint (which was not certified by peer review) is the author/funder, who has granted medRxiv a license to display the preprint in perpetuity. It is made available under a CC-BY-NC-ND 4.0 International license .

sterilized and motivate others to do so. In some cases, quotas were imposed on government employees to produce people for sterilization. In other cases, citizens were required to produce sterilization certificates to access basic facilities, such as housing, irrigation, ration cards, and public health care facilities. Some extreme measures were also undertaken in some states. For example, the state government in Maharashtra passed a bill allowing compulsory sterilization of couples with three or more children (Shah Commission of Inquiry 1978; Panandiker, Bishnoi, and Sharma 1978). ${ }^{20}$

Historical records, court rulings, and anecdotal evidence from the field suggest that quotas were imposed, incentives and disincentives were provided, coercion was enforced, and disinformation was delivered to motivate individuals to undergo sterilization during this period. ${ }^{21}$ For example, in Uttar Pradesh, over 24,000 employees of the Department of Health and Family planning were not paid their salary in June 1976 for failure to complete their quota for the April-June quarter (Panandiker, Bishnoi, and Sharma 1978). Anecdotal evidence of some of the extreme coercive measures can be seen from the following incident in Uttawar, a village in the state of Haryana, on November 6, as reported in Gwatkin (1979, p. 46):

The villagers of Uttawar were shaken from their sleep by loudspeakers ordering the menfolk-all above 15 to assemble at the bus-stop on the main Nuh-Hodol road. When they emerged, they found the whole village surrounded by the police. With the menfolk on the road, the police went into the village to see if anyone was hiding ... As the villagers tell it, the men on the road were sorted out into eligible cases ... and about 400 were taken to various thanas [headquarters towns], most to Palwal. Many had cases registered against them - a large number for alleged possession of illicit arms but most on suspicion of the threat of violence - and they were taken from there to clinics to be sterilized.

A unique feature of the family planning program during this period was that all government departments were involved in the family planning, and it was organized and administered locally (Gwatkin 1979; Shah Commission of Inquiry 1978). Additionally, the nature of the emergency rule and the executive power allowed the central government to give directions to states as to how the policies was to be exercised. The central government encouraged the states to decide and

\footnotetext{
${ }^{20}$ This was not approved by the central government and eventually returned to the state for revision.

${ }^{21}$ For a detailed discussion on quota enforcement, incentives and disincentives, coercion, disinformation, and fear of sterilization during the emergency, see Panandiker et al. (1978) and the Shah Commission of Inquiry (1978).
} 
medRxiv preprint doi: https://doi.org/10.1101/2021.01.21.21250216; this version posted August 11, 2021. The copyright holder for this preprint (which was not certified by peer review) is the author/funder, who has granted medRxiv a license to display the preprint in perpetuity.

It is made available under a CC-BY-NC-ND 4.0 International license .

implement incentives and disincentives for sterilization. ${ }^{22}$ All government departments were engaged in the family planning program, and specific targets were allotted to each of them. Coordination and supervision were delegated by the Chief Secretary (the top-ranking civil servant at the state) to the Collectors or Magistrates - the highest-ranking administrative civil servant at the district level. Under their guidance, most sterilizations were performed in temporary camps organized by the health departments. ${ }^{23}$

The aggressive family planning drive led to over 8 million sterilizations in 1976-77, more than three times the number in the previous year. During the peak, over 1.7 million sterilizations were performed in September 1976 alone, a figure that equaled the annual average for the 10 preceding years (Gwatkin 1979). The majority of the sterilizations performed during this period involved men undergoing vasectomy. Out of about 8.3 million sterilizations performed in 1976-77, about 6.2 million (about 75\%) were achieved through vasectomy. The aggressive nature of the program also led to serious consequences, including medical complications, death, and sterilization of ineligible individuals. For example, according to the report published by the Shah Commission of Inquiry (1978), 1,778 complaints of deaths related to sterilization and 548 reports regarding sterilizations of unmarried person had been registered.

Anecdotal evidence suggests that the forced sterilization policy's legacy remained in peoples' minds and can be felt even after the emergency rule is over. For example, to repair the family planning's legacy, the Indian government changed the name of the Department of Family Planning to the Department of Family Welfare. Basu (1985) found that the family planning program shifted from vasectomy to tubectomy during the post-emergency period, when women emerged as the primary target. Tarlo (2000) notes that the word "emergency" itself became synonymous with "sterilization," and many citizens even today refer to the emergency period as "nasbandi ka vakt" (the sterilization period). The emergency period remains controversial today and is still regarded as one of the darkest periods in the history of Indian democracy.

\subsection{Immunization programs in India}

\footnotetext{
${ }^{22}$ For a detailed description on the incentives and disincentives implemented at the state level, see Shah Commission of Inquiry (1978)

${ }^{23}$ There were exceptions as well. For example, the military and the railway department were given special sterilization targets, which were not a part of the state administrative unit.
} 
medRxiv preprint doi: https://doi.org/10.1101/2021.01.21.21250216; this version posted August 11, 2021. The copyright holder for this preprint (which was not certified by peer review) is the author/funder, who has granted medRxiv a license to display the preprint in perpetuity.

It is made available under a CC-BY-NC-ND 4.0 International license .

Immunization program in India was introduced in 1978 as Expanded Program of Immunization (EPI) by the Ministry of Health and Family Welfare. In 1985, it was renamed to Universal Immunization Program (UIP) when its reach was expanded beyond urban areas. The UIP was implemented in a phased manner to cover all the district by the year 1989-90. In 1990, the IUP became universalized in geographical coverage to cover 100 percent of the infants in India. Since 2005, UIP is under National Health Mission - an initiative strengthening health system in rural and urban areas - and serve as a key area of health intervention in India (Lahariya 2014).

UIP is one of the largest public health programs in the world targeting about 27 million newborns annually. ${ }^{24}$ Under UIP, immunization is currently provided against 12 vaccine preventable diseases. ${ }^{25}$ Immunization services are primarily administered through Integrated Child Development Services (ICDS) - a publicly funded program through which the Government of India promotes early-childhood health and education services. ICDS provides immunization services through anganwadi centers - a type of child care and pre-school education centers in India. According the NFHS-4 survey in 2015-16, about half of the children received most vaccinations from anganwadi centers. ${ }^{26}$ Additionally, both public and private health care facilities also provide immunization services.

Despite having a longstanding history of immunization programs and free availability of vaccines, India continues to have one of the lowest vaccination take-up rates globally and contributes to the largest pool of under-vaccinated children in the world. According to the most recent estimates, more than 300,000 children — aged 1-59 months - died from vaccine-preventable diseases in 2015, contributing to about one-third of total deaths globally. Vaccination coverage in India also varies considerably within states. The highest numbers of under-vaccinated and nonvaccinated children are found in central and northern states such as Bihar, Madhya Pradesh, Uttar Pradesh and Rajasthan.

\section{Data Sources and Description}

\footnotetext{
${ }^{24}$ Immunization :: National Health Mission. https://nhm.gov.in/index1.php?lang=1\&level=2\&sublinkid=824\&lid=220

${ }^{25}$ It is provided nationally against 9 diseases (Diphtheria, Pertussis, Tetanus, Polio, Measles, Rubella, severe form of Childhood Tuberculosis, Hepatitis B and Meningitis and Pneumonia caused by Hemophilus Influenza type B) and sub-nationally against 3 diseases (Rotavirus diarrhea, Pneumococcal Pneumonia and Japanese Encephalitis).

${ }^{26}$ ICDS centers refer to Integrated Child Development Service centers. They are linked to and a part of Anganwadi service.
} 
medRxiv preprint doi: https://doi.org/10.1101/2021.01.21.21250216; this version posted August 11, 2021. The copyright holder for this preprint (which was not certified by peer review) is the author/funder, who has granted medRxiv a license to display the preprint in perpetuity.

It is made available under a CC-BY-NC-ND 4.0 International license .

\subsection{Historical Data}

The historical data on sterilization for this paper come from the historical yearbooks published by the Ministry of Health and Family Planning, Department of Family Planning, Government of India. Along with various demographic and health statistics, the yearbooks report yearly statistics on family planning programs performed between April and March every year. Notably, the historical yearbooks include the numbers and types of sterilization performed at the state level.

We collected historical yearbooks from the Ministry of Health and Family Welfare archive and digitized the sterilization data. In Figure A2 in the appendix, we present some examples of the archival data used in this paper. Figure 1 presents the total number of sterilizations along with the types of sterilization performed in India every year since the beginning of the program in 1956. As we can see, there is a sharp increase in the total number of sterilizations performed in 1976-77. We also see that most sterilizations performed during this period were vasectomies.

In Figure A3 and Figure A4 in the Appendix, we present the total number of sterilizations performed at the state-level in 1975-76 and 1976-77, respectively. To provide a visual representation, we group the total number of sterilizations performed each year into several broad categories and denote a greater number of sterilizations performed by darker shades. As we can see, the number of sterilizations was higher in south India in 1975-76, the year before the announcement of the NPP. However, there is a shift in sterilization performance from the southern to the northern part of India after the NPP's announcement in 1976-77. Figure 2 presents a better measure of state-level variation in exposure to the forced sterilization policy as measured by the number of excess sterilizations performed in 1976-77 normalized by performance in 1975-76. As we can see, exposure to the forced sterilization policy was particularly high in northern India, especially states adjacent to New Delhi. This is likely because a large number of sterilizations performed during this period were the result of the personal influence of Mr. Sanjay Gandhi.

\subsection{Modern Data}

We combine the historical data on exposure to the forced sterilization policy with India's national representative NFHS-4 (International Institute for Population Sciences [IIPS] 2017). The NFHS4 sample is a stratified two-stage sample designed to produce indicators at the district, state, UT, and national levels, with separate estimates for urban and rural areas. The primary sampling units 
medRxiv preprint doi: https://doi.org/10.1101/2021.01.21.21250216; this version posted August 11, 2021. The copyright holder for this preprint (which was not certified by peer review) is the author/funder, who has granted medRxiv a license to display the preprint in perpetuity. It is made available under a CC-BY-NC-ND 4.0 International license .

(PSUs) in the NFHS-4 are villages in rural areas and Census Enumeration Blocks (based on the 2011 Census) in urban areas. The dataset in our main analysis includes NFHS-4 data for women. ${ }^{27}$

We also combine data on population and health care to control for potential covariates that could affect exposure to both forced sterilization and the vaccination rate. We collect population data from the 2011 population census to construct state-level population density. Additionally, we collect health care facility and health care personnel data from Rural Health Statistics to construct hospitals per 1000 population and doctors per 1000 population at the state level.

Our primary outcome variable is the vaccination rate. The NFHS-4 data report a total of 13 vaccination details for children under the age of 5 years. ${ }^{28}$ The reported vaccines are against polio (Polio 0-3), tuberculosis (BCG), hepatitis B (Hepatitis-B 0-3), diphtheria, pertussis, and tetanus (DPT 1-3), and measles. The NFHS-4 further categorizes these vaccines into three groups: basic vaccines (BCG, Measles, DPT 1-3, and Polio 1-3), age-appropriate vaccines (basic vaccinations + Hepatitis-B 0-3), and other vaccines (Polio 0). Based on the NFHS-4 classifications, we construct three vaccination indexes for our main analysis: basic vaccination, appropriate vaccination, and all vaccination. Basic vaccination is an index that measures the share of completed vaccines among the eight possible basic vaccines. Appropriate vaccination is an index that measures the share of completed vaccines among the 12 possible age-appropriate vaccines. All vaccination is an index that measures the share of completed vaccinations among all 13 possible vaccinations reported in the NFHS-4. The key benefit of considering a vaccination index measure instead of individual vaccine is that each vaccine or combination of doses is generally effective for preventing certain illnesses. Therefore, an index of vaccination completion can be considered an important health indicator. In the heterogeneous analysis, we also explore each vaccine separately as our outcome variable.

We also use additional outcome variables to examine the mechanism through which the forced sterilization policy has influenced decision-making for childhood vaccinations. Our first additional outcome variable, from the NFHS-4 data, is the noninstitutional delivery of a child. We consider this variable because the place of delivery — at home or a health care facility — is an important determinant of vaccination because some vaccines are given immediately after birth. In the NFHS-

\footnotetext{
${ }^{27}$ The sample of Sikkim and Nagaland are excluded from our analysis as we have incomplete information on sterilization in these two states.

${ }^{28}$ We exclude vitamin A supplements reported in the survey because supplements are not a vaccine.
} 
medRxiv preprint doi: https://doi.org/10.1101/2021.01.21.21250216; this version posted August 11, 2021. The copyright holder for this preprint (which was not certified by peer review) is the author/funder, who has granted medRxiv a license to display the preprint in perpetuity.

It is made available under a CC-BY-NC-ND 4.0 International license .

4 , about $20 \%$ of children are born at home (noninstitutional delivery). We test whether exposure to the forced sterilization policy has had any effect on the place of delivery of a child.

Our second additional outcome variable, from the NFHS-4 data, is the reason for noninstitutional delivery among women. We use this variable to understand whether demand- or supply-side factors affect a mother's intention to deliver her child at home. The NFHS-4 asks mothers the reasons for the noninstitutional delivery of their child and reports a total of nine. ${ }^{29}$ First, we consider each possible reason separately as our outcome of interest. Second, we combine the information on reasons reported and construct two indexes, demand-side and supply-side, and examine whether demand or supply-side factors affect the mother's intention to deliver the child at home.

Our third additional outcome variable, also from the NFHS-4 data, is the mother's data on ANC visits during pregnancy. We consider this variable to test the channel of information provision because an antenatal visit to health care centers can also be an essential source of receiving reliable and accurate information regarding a child's future health-seeking behavior, such as vaccination practice. The NFHS-4 also provides information on the mother's ANC records for her most recent pregnancy. In our sample, about $87 \%$ of mothers received ANC, and conditional on receiving ANC, the average number of visits was about 5.8. We construct two outcome variables from these data: 1) whether the mother received ANC, and 2) the number of visits conditional on receiving ANC. We test whether exposure to the forced sterilization policy has any effect on ANC.

Our fourth and final additional outcome variable is the child mortality. We consider this variable to test the consequences of childhood vaccination. The NFHS-4 has information about the mortality record of children below the age of 5 in the household. In our sample, about 12,000 (about 4.5\%) children have died. We test whether exposure to the forced sterilization policy has had any effect on child mortality.

\section{Empirical Analysis}

\subsection{Correlation and OLS Estimates}

We begin by examining the relationship between historical exposure to the forced sterilization policy and India's current vaccination rate. In Figure 3, we present a simple correlation plot

\footnotetext{
${ }^{29}$ The reasons include: cost too high, facility not open, too far/no transportation, no female provider, no trust in a health care facility/poor service quality, not allowed by the husband or family, not necessary, not customary, and others.
} 
medRxiv preprint doi: https://doi.org/10.1101/2021.01.21.21250216; this version posted August 11, 2021. The copyright holder for this preprint

between exposure to the forced sterilization policy and the all vaccination index in $2015-16 .{ }^{30}$ In Panel A, we present the correlation between the state-level total number of sterilizations performed in 1976-77 and the all vaccination index in 2015-16. In Panel B, we present the correlation considering a better measure of exposure to the forced sterilization policy, as measured by statelevel excess sterilizations performed in 1976-77 normalized by performance in the year before, 1975-76 (we discuss this variable in detail below). As we can see, a strong negative relationship between exposure to the forced sterilization policy and the vaccination rate is apparent in the raw data.

We then examine this relationship by controlling for individual, household, geographic, and health care characteristics that are also potentially important for India's current vaccination rate. Our baseline estimating equation is:

$$
y_{\text {ihcs }}=\alpha+\beta \text { Forced Sterilization }_{\mathrm{s}}+\gamma_{1} \mathrm{X}_{\mathrm{ihcs}}^{\prime}+\gamma_{2} \mathrm{X}_{\mathrm{hcs}}^{\prime}+\gamma_{3} \mathrm{X}_{\mathrm{cs}}^{\prime}+\gamma_{4} \mathrm{X}_{\mathrm{s}}^{\prime}+\varepsilon_{\text {ihcs }}
$$

where $y_{\text {ihcs }}$ denotes one of our vaccination measures for child $i$ living in household $h$ in NFHS-4

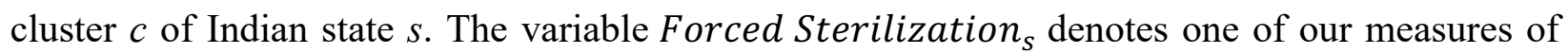
exposure to the forced sterilization policy in state $s$ (we discuss this variable in more detail below).

We include $X_{i h c s}^{\prime}$, a vector of child-level covariates, which includes an indicator variable for child's gender, month by year of birth fixed effects, an indicator for whether the child is a twin, and birth order of the child. The vector $X_{h c s}^{\prime}$ consists of household-level covariates, including the age and sex of the household head, household size, number of household members below the age of 5 years, seven religion fixed effects, four caste fixed effects, 20 education of the mother fixed effects, four household wealth index fixed effects, and an indicator for whether any household member is covered by health insurance. These child-level and household characteristics that we control have been shown to be correlated with the vaccination rate in India. $X_{c S}^{\prime}$ is a vector of NFHS-4 cluster-level covariates that captures the characteristics of the place where the child lives, such as altitude in meters, altitude squared, and an indicator of whether the cluster is urban. $X_{S}^{\prime}$ is a vector of covariates meant to capture state-level characteristics that are likely to be correlated

\footnotetext{
${ }^{30}$ In Figures A5 and A6 in the Appendix, we also present a correlation plot for the appropriate and all vaccination indexes, respectively.
} 
medRxiv preprint doi: https://doi.org/10.1101/2021.01.21.21250216; this version posted August 11, 2021. The copyright holder for this preprint (which was not certified by peer review) is the author/funder, who has granted medRxiv a license to display the preprint in perpetuity. It is made available under a CC-BY-NC-ND 4.0 International license .

with vaccination, including population density per square kilometer (in log), hospitals per 1000 population, and doctors per 1000 population. Finally, $\varepsilon_{\text {ihcs }}$ is a random, idiosyncratic error term, capturing all omitted factors, which we allow to be heteroscedastic and correlated across children; in practice, the standard errors we report in our baseline estimates are clustered at NFHS-4 cluster level. ${ }^{31}$

We present the OLS estimates for the impact of Forced Sterilization s $_{\mathrm{s}}$ on the vaccination rate measured by the all-vaccination index in Table $1 .{ }^{32}$ In column 1 , we use the total number of sterilizations performed in a state in 1976-77 (expressed in 100,000 individuals) as our measure of exposure to the forced sterilization policy. The estimated coefficient for Forced Sterilization , $\beta$, is negative and statistically significant. This suggests that higher exposure to the forced sterilization policy has an adverse effect on the vaccination completion rate. Because the distribution of the number of sterilizations performed in 1976-77 is skewed, with a small number of observations taking on large values, we report estimates using the natural log of the number of sterilizations performed in 1976-77 in column 2. The results are similar, as we find a significant negative correlation between forced sterilizations and the vaccination rate.

In columns 1 and 2, we use the total number of sterilizations performed in 1976-77 to measure exposure to the forced sterilization policy. One limitation of this measure is that it does not account for the number of sterilizations that would have happened anyway in the absence of the NPP. Accounting for this difference is important because sterilization, as a family planning method, has been performed in India since the 1950s, as shown in Figure 1. In column 3, we account for this issue and use an alternative measure of the forced sterilization policy based on the number of excess sterilizations performed in 1976-77 over and above the 1975-76 numbers. ${ }^{33}$ Additionally, in column 4, we report estimates using the natural log of the excess number of sterilizations performed in 1976-77. As we see, the results are similar using these alternative forced sterilization measures.

\footnotetext{
${ }^{31}$ As we mentioned before, NFHS-4 is a stratified two-stage sample designed to produce indicators at the district, state, and national levels and separate estimates for urban and rural areas. Therefore, undersampling and oversampling are observed in many places. To account for this issue, we conduct the regression analysis using weights defined in the NFHS-4.

${ }^{32}$ In Section B of the Appendix, we present the results for the basic and appropriate vaccination indexes.

${ }^{33}$ Alternative measures of excess sterilization performed in 1976-77, such as deducting the average of the last 2 or 3 years, are also possible. Using such alternative measures produced nearly identical results.
} 
medRxiv preprint doi: https://doi.org/10.1101/2021.01.21.21250216; this version posted August 11, 2021. The copyright holder for this preprint (which was not certified by peer review) is the author/funder, who has granted medRxiv a license to display the preprint in perpetuity. It is made available under a CC-BY-NC-ND 4.0 International license .

The estimates we report in columns 3 and 4 use the absolute number of sterilizations to measure the forced sterilization policy. Some shortcomings of these measures are that they 1) do not account for the difference in the size of states, and 2) do not account for any state-wide historical factors associated with the level of sterilization performance that we do not capture in our estimation. To account for these issues, in column 5, we report the estimates normalizing the excess sterilizations performed using sterilization figures for the previous year (1975-76). Specifically, we define Forced Sterilization $_{s}$ as,

$$
\text { Excess Sterilization }_{s}=\frac{\# \text { of sterilizations in 1976 } 77_{s}-\# \text { of sterilizations } 1975 \sim 76_{s}}{\# \text { of sterilizations } 1975 \sim 76_{s}}
$$

We normalized the previous years' figures to account for the effect of emergency rule in India and isolate the impact of forced sterilization policy from India's emergency rule. ${ }^{34}$ This is because India's emergency rule could itself affect our outcome in several ways as this period was largely governed by autocratic rule and involved numerous policy changes. As we see, the results we obtain in column 5 remain robust to this alternative specification.

For the remainder of our analysis, we use state-level excess sterilizations performed in 1976-77 normalized by the sterilization figure in 1975-76 (the specification from column 5). This provides a better measure that accounts for India's emergency rule and is normalized by both size and statelevel historical characteristics associated with sterilization performance. However, as illustrated in Table 1, our results do not rest on this choice only.

We now turn to examine the impact of the forced sterilization policy on other vaccination measures. In Table 2, we report the OLS estimates of all three vaccination indexes. The estimates in Table 2 suggest that the forced sterilization policy is negatively correlated with all three measures of vaccination. In terms of magnitude, column 3 of Table 2 indicates that an average increase in excess sterilizations (about 3.45 times) leads to a decline of about 3 percentage points in the all-vaccination index.

In section $\mathrm{C}$ of the Appendix, we present a series of robustness tests. We only briefly discuss them here. We present the results of Table 2, adding each set of controls sequentially for each outcome, an analysis with children aged between 12 and 23 months (to capture the Indian

\footnotetext{
${ }^{34}$ Using alternative measures such as normalizing by the average of the last 2 or 3 years produced nearly identical results.
} 
medRxiv preprint doi: https://doi.org/10.1101/2021.01.21.21250216; this version posted August 11, 2021. The copyright holder for this preprint (which was not certified by peer review) is the author/funder, who has granted medRxiv a license to display the preprint in perpetuity.

It is made available under a CC-BY-NC-ND 4.0 International license .

government's official vaccination estimate), and considering excess male sterilization (vasectomy), which constituted the majority of sterilization operations (about 75\%), as an alternative measure

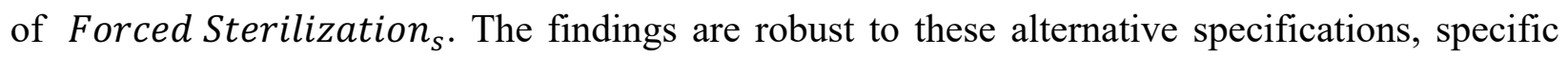
cohorts, and different measures of the forced sterilization policy.

\subsection{Estimates}

In the previous section, we presented results suggesting a negative association between historical exposure to the forced sterilization policy and vaccination. We also showed several alternative estimations to provide robust evidence. However, the correlation we found may not necessarily identify the causal effect of forced sterilization on vaccination. For example, the correlation could also be explained by some omitted variables that determine both exposures to forced sterilization and the vaccination rate.

To address this concern, in this section, we present results by pursuing an instrumental variable approach. We need an instrument that is correlated with sterilization performance during the forced sterilization period but does not affect vaccination through any channels other than forced sterilization. We use distance from New Delhi to state capitals as an instrument to capture the variation in exposure to the forced sterilization policy.

The history of forced sterilization policy during India's emergency rule leaves little doubt that our instrument is relevant. Various sources, including Gwatkin (1979), Vicziany (1982), Chandra (2017), Indian National Congress (2011), Nayar (2013), and Williams (2014), describe the forced sterilization policy was aggressively undertaken owing to the active role played by Sanjay Gandhi. It is well known that family planning was a key element of his self-declared five-point program, and became the central theme of public addresses during the latter part of the emergency period. Mr. Gandhi and his colleagues in Delhi were at the center of the action and continuously influenced regional political leaders, particularly those in the states adjacent to the national capital of Delhi, over whom they had an influence (Shah Commission of Inquiry 1978). Consequently, northern parts of India, such as Haryana, Delhi, Rajasthan, and Uttar Pradesh, were later popularly known as the "vasectomy belt" because a large number of (male) sterilizations were performed in these states during this period. Gwatkin (1979) describes that the distance to state capitals from New Delhi (as a proxy of Mr. Gandhi's influence), which was previously irrelevant, emerged as an important determinant of excess sterilization performance and was itself capable of explaining two-thirds of the variation in performance among states. 
medRxiv preprint doi: https://doi.org/10.1101/2021.01.21.21250216; this version posted August 11, 2021. The copyright holder for this preprint (which was not certified by peer review) is the author/funder, who has granted medRxiv a license to display the preprint in perpetuity.

It is made available under a CC-BY-NC-ND 4.0 International license .

To provide a visual understanding, we present Gwatkin's (1979) insight on distance from New Delhi as an important determinant of excess sterilization performance in Figure 4. In panel (A), we plot the correlation between the distance to state capitals from New Delhi and Forced Sterilization $_{s}$ as measured by excess sterilizations in 1976-77. In panel (B), we present the same correlation, but instead consider excess sterilizations in 1975-76. As we can see, the correlation is negative in panel (A); however, we do not see any correlation in panel (B). Based on these insights, we use the distance to state capitals from New Delhi as an instrument to capture the variation in exposure to the forced sterilization policy.

We present the IV estimates in Table 3. Panel A presents the first stage estimates for the instrument we considered in our analysis. As we expected, the instrument is a strong predictor of the forced sterilization policy as measured by excess sterilizations. In Panel B, we present the second stage estimates. Column 3 of Table 3 indicates that an average increase in excess sterilizations (from zero to 3.45 times) decreases the completion of all vaccinations by about 8.1 percentage points. This is relative to a baseline completion of $32.1 \%$ for the sample as a whole, which suggests a large effect of exposure to the forced sterilization policy on current vaccination rate in India.

\subsection{Adjusting Standard Errors for Alternative Clustering}

Thus far, we have shown all our estimates by clustering our standard errors at the NFHS-4 primary sampling unit (PSU) level. We adjust our standard errors clustering at the NFHS-4 PSU level primarily because of the design and selection of the NFHS-4 sample (Abadie et al. 2017). Our main assumptions for this way of clustering relies on the fact that children in the same village (or Census Enumeration Block in urban areas) are more likely to have been subject to common unobserved forces that may affect their current vaccination behavior.

However, likely, the within-group correlation of the residuals could also exist at different levels. For example, the standard errors may be correlated at a higher level of administrative boundaries than the PSU as many of the explanatory variables in our estimation do not vary across these clusters. Additionally, we also need to account for the issue of spatial correlation in our standard errors. As Kelly (2019) argues, persistence regressions are spatial regressions. Places in the real world are not scattered randomly across the landscape but instead clump together. Therefore, spatial data tend to be autocorrelated. In our case, for example, Indian villages might be clustered 
medRxiv preprint doi: https://doi.org/10.1101/2021.01.21.21250216; this version posted August 11, 2021. The copyright holder for this preprint (which was not certified by peer review) is the author/funder, who has granted medRxiv a license to display the preprint in perpetuity.

It is made available under a CC-BY-NC-ND 4.0 International license .

according to geography rather than administrative boundaries. ${ }^{35}$ Thus, adjusting standards errors according to administrative boundaries alone — such as village, district, or state - may produce biased results.

We present the estimates with four different types of clustering choices in Table 3. We report our usual standard errors based on NFHS-4 PSU in parentheses. In square brackets, we report the standard errors adjusted for clustering at the current district levels. In curly brackets, we report the standard errors adjusted at the current state levels. Finally, to account for the spatial autocorrelation in our estimation, we adjust the standard errors using the spatial correction proposed by Conley (1999) and report them in double parenthesis. ${ }^{36}$ As we can observe, our results are overall robust to adjusting standard errors for these alternative levels of clustering.

In section $\mathrm{D}$ of the Appendix, we present a series of alternative analyses showing that our results are also robust to sequential inclusion of controls in Table 3, consideration of specific cohorts, and

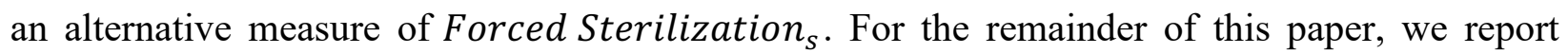
standard errors adjusted for clustering at the current state level. We opt for the state-clustered standard errors from now onwards because they tend to be most conservative for the IV estimates and very similar for the first stage - as we can see from Table 3 and section D of the Appendix.

\subsection{Testing Exogeneity of the Instrument}

In section 4.2, we presented anecdotal evidence by Gwatkin (1979) suggesting that the instrument we use (i.e., distance to state capital from New Delhi) is plausibly exogenous. We provide some evidence through a correlation plot suggesting that our instrument is not correlated with sterilization performance in the previous year. In this section, we perform two falsification exercises to examine the potential concern about the exogeneity of our instrument. First, we perform a placebo IV analysis to examine formally whether distance to state capital from New Delhi predicts excess sterilizations in 1975-76 in the first stage and the vaccination rate in the second. Next, we perform a second placebo IV analysis to examine whether our instrument

\footnotetext{
35 The same can also be true for Indian districts and states.

${ }^{36}$ We use the procedures proposed by Colella et al. (2019) to calculate Conley standard errors (acreg command in STATA) with cutoffs at a distance of $100 \mathrm{~km}$ beyond the observations belonging to the same cluster. We use the bartlett option that allows for weights in the matrix linearly decreasing as the distance increases with values very close to one for near observations and almost zero for those close to the distance cutoff. Different choices of distances (such as 25, 50, and 200 kilometers) and the use of binary weights (no bartlett option) produce nearly identical results.
} 
medRxiv preprint doi: https://doi.org/10.1101/2021.01.21.21250216; this version posted August 11, 2021. The copyright holder for this preprint (which was not certified by peer review) is the author/funder, who has granted medRxiv a license to display the preprint in perpetuity.

It is made available under a CC-BY-NC-ND 4.0 International license .

predicts excess female sterilization during the forced sterilization period (which was not the main focus during this period) and the subsequent vaccination rate.

\subsubsection{Exposure to Sterilization Before the Forced Sterilization Period}

Our first exercise consists of examining sterilizations performed before 1976. Because Mr. Gandhi had no personal influence over the sterilization before 1976, our instrumental variable-if exogenous - should have no predictive power on sterilization performance before 1976 . We formally test this by estimating a placebo IV analysis considering excess sterilizations performed in 1975-76, the year immediately before the implementation of the forced sterilization policy. We present the results in columns 1-3 of Table 4. As we can see, the distance to state capitals from New Delhi has no predictive power for excess sterilizations performed in 1975-76 in the first stage or the vaccination rate in the second.

\subsubsection{Exposure to Female Sterilization (Tubectomy):}

Our second exercise consists of female sterilization, or tubectomy, which was not the focus during India's forced sterilization period (Gwatkin 1979; Shah Commission of Inquiry 1978). During the period of emergency rule, the forced sterilization program mostly focused on men undergoing vasectomy, as can be seen from Figure 1. The main reason for the heavy reliance on vasectomy was the simplicity of the procedure. Tubectomy operations constitute major abdominal surgery, whereas vasectomies are relatively quick to perform and patients can be discharged on the same day of the operation. During the period of emergency rule, the authorities relied on vasectomy, as sterilization was mostly performed in temporary camps. The existing infrastructure also struggled to cope with the large number of operations because of increased pressure and intentions to meet the target (Gwatkin 1979). Therefore, although vasectomy was not a part of the constructed family planning scheme during this period, it was necessary to reach the required target owing to the pressure of time scales (Scott 2017).

This narrative provides a falsification test for our instrument. We formally test whether distance to state capitals from New Delhi predicts the variation in excess female sterilizations performed during the forced sterilization period. Columns 4-6 of Table 4 present the results of our falsification exercise. As we can see, our instrumental variable has no predictive power for excess female sterilizations performed during the forced sterilization period in the first stage or the vaccination rate in the second. 
medRxiv preprint doi: https://doi.org/10.1101/2021.01.21.21250216; this version posted August 11, 2021. The copyright holder for this preprint

\section{Heterogeneous Effects of Forced Sterilization on Vaccination}

We next turn to examine the heterogeneous effect of the forced sterilization policy on the current vaccination rate. To do this, we explore each vaccination separately to understand whether the lower vaccination rate we observe differs for some vaccines or any particular doses. Understanding the heterogeneous effect is important because 1) different vaccines are given to children at different points of time, and 2) multiple doses of the same vaccines are given for full immunization. For example, according to India's National Immunization Schedule, the first dose of polio and hepatitis $B$ vaccine (Polio 0 and Hepatitis B 0 ) should be given immediately after birth, whereas the measles vaccine is generally given between age 9 and 12 months. Similarly, vaccines such as hepatitis, DPT, and polio are given to children multiple times for full immunization.

We plot the IV regression coefficients for each vaccine in Figure $5 .{ }^{37}$ The results in Figure 5 suggest two interesting findings. First, we find that higher exposure to the forced sterilization policy has the largest negative and statistically significant effect on vaccines given at birth (i.e., Hepatitis 0 and Polio 0). Second, although not robust, we also find some indications that the vaccination rate declines with higher doses for vaccines administered multiple times, such as hepatitis, DPT, and polio. In Section E of the Appendix, we present alternative estimates examining specific cohorts, such as those between the age of 13 and 24 months, and alternative measures of the forced sterilization policy as measured by excess male sterilization. Overall, our analysis provides evidence that the forced sterilization policy has heterogeneous effects on vaccination and, in particular, the largest and significant effects on vaccines given at birth.

\section{Understanding the Mechanisms: Why are the effects still persistent?}

Up to this point, we have found that the forced sterilization policy has had a significant and sizable effect on India's vaccination rate. We have also found that the policy has heterogeneous effects on different vaccines. In particular, we found that the policy has significant effect on vaccines given at birth. In this section, we aim to better understand the plausible channels or mechanisms through which the forced sterilization policy has affected India's current vaccination rate. First, we explore whether the place of delivery of a child is a possible channel considering the results of our

\footnotetext{
${ }^{37}$ We present the results in tabular form in Table E1 in the appendix.
} 
medRxiv preprint doi: https://doi.org/10.1101/2021.01.21.21250216; this version posted August 11, 2021. The copyright holder for this preprint (which was not certified by peer review) is the author/funder, who has granted medRxiv a license to display the preprint in perpetuity.

It is made available under a CC-BY-NC-ND 4.0 International license .

heterogeneous analysis. Second, we examine an indirect channel of information provision through ANC.

\subsection{Place of Delivery}

Place of delivery - at home or in a health care facility - is an important determinant for vaccinations because some vaccines are given immediately after birth. We test whether exposure to the forced sterilization policy has any effect on the place of delivery. The NFHS-4 includes a question on the place of birth of the child. About $20 \%$ of the children in our sample were associated with noninstitutional delivery, such as at the homes of the respondents, their parents, or others.

For a simple visualization, we present the association between exposure to the forced sterilization policy and the percent of children who had noninstitutional delivery at the state-level through a scatter plot in Figure 6. As we can see, a strong positive association is apparent in the raw data. We then present the IV estimates in Table 5. As we can see, the coefficient of excess sterilization is sizable, positive, and significant. This suggests that exposure to the forced sterilization policy has a large, positive, and significant effect on noninstitutional delivery. Table F1 of the Appendix presents the results considering alternative forced sterilization policy measures as measured by excess male sterilization. Again, the results are similar, suggesting that higher exposure to the forced sterilization policy positively affects child delivery at home.

We dig a little further and also check the reasons for noninstitutional delivery. The NFHS-4 asks mothers for reasons for not delivering their child in a health care facility. Both demand- and supply-side constraints are reported, such as higher costs, facility not open, facility being far/no transportation, no female provider, no trust in the health care facility/poor service quality, not allowed by the husband or family, not necessary, not customary, and others. We present each answer's estimates separately in Figure $7 .{ }^{38} \mathrm{We}$ also present estimates by indexing the reasons, both supply- and demand-side, in Table F4 of the Appendix.

Notably, the coefficients of individual answers and average effect size coefficients suggest that the effect of exposure to the forced sterilization policy on supply-side constraints is minimal, sometimes negative, and statistically insignificant. However, the effects of the forced sterilization policy on demand-side constraints are large, positive, and statistically significant. These results

\footnotetext{
${ }^{38}$ We present the results in tabular form in Table F2 in the appendix. In Table F3, we also present estimates showing that the results presented in Figure 7 are robust to alternative measures of the forced sterilization policy as measured by excess male sterilizations.
} 
medRxiv preprint doi: https://doi.org/10.1101/2021.01.21.21250216; this version posted August 11, 2021. The copyright holder for this preprint (which was not certified by peer review) is the author/funder, who has granted medRxiv a license to display the preprint in perpetuity.

It is made available under a CC-BY-NC-ND 4.0 International license .

suggest that, despite having access to medical facilities and the ability to afford medical expenses to deliver at the hospital, mothers are less likely to seek out institutional delivery the greater the exposure to sterilization policy, primarily due to demand-side constraints. The supply-side results are also consistent with Indian context because the Indian government promotes and pays for institutional delivery, especially among poor households, through Janani Suraksha Yojana (Maternal Protection Scheme) since 2005.

\subsection{Information Provision through Antenatal Care (ANC)}

In this section, we examine an additional mechanism of information provision. Several studies have shown that information provision is important to generate a take-up rate in health-seeking behavior. ${ }^{39}$ We test this channel in India's context in general and vaccination in particular because one of the main challenges for India's recent vaccination campaign is concern about the circulation of misinformation, rumors, and conspiracy theories, including vaccines causing sterilization (Gurnani et al. 2018). We hypothesize that in such an environment, the provision of reliable and accurate information can help increase the vaccination take-up rate.

We study information provision mechanism through ANC. ANC not only is important to reduce the health risks for mothers and their babies during pregnancy, but also can be an essential source of reliable and accurate information regarding a child's future health-seeking behavior, such as vaccination practice. The NFHS-4 asks a question about the mother's ANC records for her most recent pregnancy. In our sample, about $83 \%$ of mothers received $\mathrm{ANC}$, and conditional on receiving ANC, the average number of visits was about 5.6 times. We test whether exposure to the forced sterilization policy has had any effect on receiving ANC and the number of visits.

We first present the associations through scatter plots in Figure 8. As we can see, there is a negative correlation between exposure to sterilization on the probability of receiving ANC in panel $\mathrm{A}$ and the number of visits conditional on receiving ANC in panel B. We then present the IV results in Table 6. Column 1 presents the results on exposure to the forced sterilization policy on the probability of receiving ANC. Column 2 reports the results on exposure to the forced sterilization policy on the number of ANC visits conditional on receiving ANC. We find that exposure to the forced sterilization policy has a large, negative, and significant effect on visiting a health care center for ANC and the number of visits conditional on receiving ANC. These results suggest that

\footnotetext{
${ }^{39}$ See Dupas and Miguel (2017) for a review.
} 
medRxiv preprint doi: https://doi.org/10.1101/2021.01.21.21250216; this version posted August 11, 2021. The copyright holder for this preprint (which was not certified by peer review) is the author/funder, who has granted medRxiv a license to display the preprint in perpetuity.

It is made available under a CC-BY-NC-ND 4.0 International license .

a lack of reliable and accurate information provision may also be an important channel. In Table F5 of the Appendix, we present estimates showing that the results presented in Table 6 are robust to alternative measures of the forced sterilization policy.

\section{Consequence}

Finally, we examine the consequence of lower vaccination caused by the forced sterilization policy. To examine the consequence, we test whether exposure to the forced sterilization policy affects child mortality. We test child mortality as the consequence of lower vaccination because studies have shown that about two-thirds of deaths in children in India are due to vaccine-preventable diseases (Liu et al. 2016). The NFHS-4 has information about the mortality records of children below the age of 5 in the household. In our sample, about $4.5 \%$ of children below the age of 5 have died. ${ }^{40}$ We test whether exposure to the forced sterilization policy has had any effect on child mortality.

We present the association through a scatter plot in Figure 9 and the IV results in Table 7. As we can see, a positive association is apparent from Figure 9. The coefficient of excess sterilization in Table 7 is also positive, statistically significant, and quite large. An average increase in excess sterilization - from zero to about 3.5 times — increases the probability of child under the age of 5 not alive by about 2.7 percentage points, relative to a sample mean of $4.5 \%$. This suggests that exposure to the forced sterilization policy has a sizable effect on child mortality. In Section G of the Appendix, we present estimates by examining an alternative measure of the forced sterilization measured by excess vasectomy. Again, the results are similar, suggesting that higher exposure to the forced sterilization policy positively affects child mortality.

\section{Conclusion}

In this paper, we have examined the importance of historical events explaining lower vaccination paradox in India. In particular, we examined whether the aggressive family planning program under which a forced sterilization policy was implemented during the period of emergency rule in the 1970 s could partly explain India's lower vaccination rates today.

\footnotetext{
${ }^{40}$ Unfortunately, we do not have any detailed information about the cause of death which would have allowed us to examine in detail. Also note that, this sample does not include the number of children died before their birth, such as due to abortion.
} 
medRxiv preprint doi: https://doi.org/10.1101/2021.01.21.21250216; this version posted August 11, 2021. The copyright holder for this preprint (which was not certified by peer review) is the author/funder, who has granted medRxiv a license to display the preprint in perpetuity. It is made available under a CC-BY-NC-ND 4.0 International license .

We examined vaccination rates using data from the NFHS-4. We found that greater exposure to the forced sterilization policy has had negative effects on the current vaccination completion rate. In the heterogeneous analysis, we explored each vaccination separately and found that higher exposure to the forced sterilization policy has had the largest effect on vaccines given at birth. Second, although not robust, we also found that the vaccination rate declined with higher doses for vaccines administered multiple times.

We then examined plausible mechanisms. First, we examined whether the place of delivery was a possible channel considering the results from our heterogeneous analysis. We found that exposure to the forced sterilization policy has had a large, positive, and significant effect on noninstitutional delivery. Going a bit further, we also checked the reasons for noninstitutional delivery. We found that demand-side factors are important drivers of such practice. Additionally, we also tested some plausible indirect channels of information provision through ANC. We found that exposure to the forced sterilization policy has had a large, negative, and significant effect on mothers' visits to health care centers for ANC during pregnancy and the number of visits conditional on receiving ANC. These results suggest that a lack of reliable and accurate information provision could also be an important channel. Finally, we examined the consequence of lower vaccination measured by child mortality. We found that exposure to the forced sterilization policy has had a positive and large effect on child mortality.

Our results provide robust evidence suggesting that historical events have had a strong impact on shaping India's current vaccination practice. This has implications for understanding the puzzling factors behind the lower demand for health-seeking behaviors, such as vaccination, even if the potential cost in morbidity and mortality is high and services are available for free. The findings from this paper also highlight the unintended consequences associated with domestic policies implemented in the past and the importance of understanding such contexts for the design and implementation of future interventions. This has important implications for public policy since several countries currently pursue evidence-based policy-making through experimentation. We empirically show that a policy failure (or success) could have spillover effects and could affect subsequent policies in the long-run.

Finally, considering the current state of the COVID-19 pandemic, vaccination in India's context currently is of substantive interest as about one-sixth of the world's population lives there. As the world rushes towards universal vaccination, our results also provide implications for policy- 
medRxiv preprint doi: https://doi.org/10.1101/2021.01.21.21250216; this version posted August 11, 2021. The copyright holder for this preprint (which was not certified by peer review) is the author/funder, who has granted medRxiv a license to display the preprint in perpetuity.

It is made available under a CC-BY-NC-ND 4.0 International license.

makers and practitioners to understand the factors affecting India's vaccination practice and carve out a pragmatic policy to maximize the uptake of the new vaccines. 
medRxiv preprint doi: https://doi.org/10.1101/2021.01.21.21250216; this version posted August 11, 2021. The copyright holder for this preprint (which was not certified by peer review) is the author/funder, who has granted medRxiv a license to display the preprint in perpetuity.

It is made available under a CC-BY-NC-ND 4.0 International license .

\section{References}

Abadie, Alberto, Susan Athey, Guido W Imbens, and Jeffrey Wooldridge. 2017. "When Should You Adjust Standard Errors for Clustering?” No. w24003. National Bureau of Economic Research Working Paper.

Acemoglu, Daron, Simon Johnson, and James A Robinson. 2001. "The Colonial Origins of Comparative Development: An Empirical Investigation.” American Economic Review 91 (5): 1369-1401.

Alsan, Marcella, and Marianne Wanamaker. 2018. "Tuskegee and the Health of Black Men.” Quarterly Journal of Economics 133 (1): 407-55. https://doi.org/10.1093/qje/qjx029.

Banerjee, Abhijit Vinayak, Esther Duflo, Rachel Glennerster, and Dhruva Kothari. 2010. "Improving Immunisation Coverage in Rural India: Clustered Randomised Controlled Evaluation of Immunisation Campaigns with and without Incentives.” Bmj 340.

Basu, Alaka M. 1985. "Family Planning and the Emergency: An Unanticipated Consequence." Economic and Political Weekly, 422-25.

BBC. 2021. "India Covid-19: Misleading Claims Shared about Vaccines - BBC News.” 2021. https://www.bbc.com/news/55768656.

Black, Robert E, Simon Cousens, Hope L Johnson, Joy E Lawn, Igor Rudan, Diego G Bassani, Prabhat Jha, et al. 2010. "Global, Regional, and National Causes of Child Mortality in 2008: A Systematic Analysis.” The Lancet 375 (9730): 1969-87.

Centers for Disease Control and Prevention (CDC). 2013. "Global Routine Vaccination Coverage-2012.” MMWR. Morbidity and Mortality Weekly Report 62 (43): 858-61.

Chandra, Bipan. 2017. In the Name of Democracy: JP Movement and the Emergency. Penguin UK.

Chernozhukov, Victor, Mert Demirer, Esther Duflo, and Iván Fernández-Val. 2020. “Generic Machine Learning Inference on Heterogeneous Treatment Effects in Randomized Experiments.” NBER WORKING PAPER SERIES. http:/www.nber.org/papers/w24678.

Colella, Fabrizio, Rafael Lalive, Seyhun Orcan Sakalli, and Mathias Thoenig. 2019. “Inference with Arbitrary Clustering." No. 12584. IZA Discussion Paper. 
medRxiv preprint doi: https://doi.org/10.1101/2021.01.21.21250216; this version posted August 11, 2021. The copyright holder for this preprint (which was not certified by peer review) is the author/funder, who has granted medRxiv a license to display the preprint in perpetuity.

It is made available under a CC-BY-NC-ND 4.0 International license .

Conley, T.G. 1999. “GMM Estimation with Cross Sectional Dependence.” Journal of Econometrics 92 (1): 1-45. https://doi.org/10.1016/S0304-4076(98)00084-0.

Dhar, Prithvi Nath. 2018. “Indira Gandhi the'Emergency'and Indian Democracy.” In . Oxford. Dupas, Pascaline. 2011. "Health Behavior in Developing Countries.” Annual Review of Economics 3 (1): 425-49.

Dupas, Pascaline, and Edward Miguel. 2017. "Impacts and Determinants of Health Levels in Low-Income Countries." In Handbook of Economic Field Experiments, 2:3-93. Elsevier.

Francis, Mark Rohit, Hanna Nohynek, Heidi Larson, Vinohar Balraj, Venkata Raghava Mohan, Gagandeep Kang, and J Pekka Nuorti. 2018. "Factors Associated with Routine Childhood Vaccine Uptake and Reasons for Non-Vaccination in India: 1998--2008.” Vaccine 36 (44): 6559-66.

Ghosh, Arpita, and Ramanan Laxminarayan. 2017. "Demand-and Supply-Side Determinants of Diphtheria-Pertussis-Tetanus Nonvaccination and Dropout in Rural India." Vaccine 35 (7): $1087-93$.

Gurnani, Vandana, Pradeep Haldar, Mahesh Kumar Aggarwal, Manoja Kumar Das, Ashish Chauhan, John Murray, Narendra Kumar Arora, Manoj Jhalani, and Preeti Sudan. 2018. "Improving Vaccination Coverage in India: Lessons from Intensified Mission Indradhanush, a Cross-Sectoral Systems Strengthening Strategy.” Bmj 363.

Gwatkin, Davidson R. 1979. "Political Will and Family Planning: The Implications of India's Emergency Experience." Population and Development Review, 29-59.

Hewitt, Vernon. 2007. Political Mobilisation and Democracy in India: States of Emergency. Routledge.

Hindustan Times. 2021. “'Can Covid-19 Vaccine Cause Infertility?' On Twitter, Health Minister Harsh Vardhan Dispels Myths | Hindustan Times," 2021. https://www.hindustantimes.com/india-news/on-twitter-health-minister-harsh-vardhandispels-myths-about-covid-19-vaccines-101610644889503.html.

"Immunization :: National Health Mission.” n.d. Accessed April 23, 2021. https://nhm.gov.in/index1.php?lang=1\&level=2\&sublinkid=824\&lid=220. 
medRxiv preprint doi: https://doi.org/10.1101/2021.01.21.21250216; this version posted August 11, 2021. The copyright holder for this preprint (which was not certified by peer review) is the author/funder, who has granted medRxiv a license to display the preprint in perpetuity. It is made available under a CC-BY-NC-ND 4.0 International license .

India Today. 2021. “Can COVID-19 Vaccine Cause Infertility? Here's What Dr Harsh Vardhan Has to Say," 2021. https:/www.businesstoday.in/latest/trends/can-covid-19-vaccine-causeinfertility-here-is-what-dr-harsh-vardhan-has-to-say/story/427983.html.

Indian National Congress. 2011. Congress and the Making of the Indian Nation. Academic Foundation New Delhi.

International Institute for Population Sciences (IIPS). 2017. "National Family Health Survey (NFHS-4), 2015--16.” International Institute for Population Sciences (IIPS), Mumbai, India.

Kelly, Morgan. 2019. “The Standard Errors of Persistence.” SSRN Electronic Journal. https://doi.org/10.2139/ssrn.3398303.

Lahariya, Chandrakant. 2014. “A Brief History of Vaccines \& Vaccination in India.” Indian Journal of Medical Research. Indian Council of Medical Research. /pmc/articles/PMC4078488/.

Liu, Li, Shefali Oza, Dan Hogan, Yue Chu, Jamie Perin, Jun Zhu, Joy E Lawn, Simon Cousens, Colin Mathers, and Robert E Black. 2016. "Global, Regional, and National Causes of under-5 Mortality in 2000--15: An Updated Systematic Analysis with Implications for the Sustainable Development Goals.” The Lancet 388 (10063): 3027-35.

Lowes, Sara, and Eduardo Montero. 2021. "The Legacy of Colonial Medicine in Central Africa.” American Economic Review 111 (4): 1284-1314. https://doi.org/10.1257/aer.20180284.

Martinez-Bravo, Monica, and Andreas Stegmann. 2021. "In Vaccines We Trust? The Effects of the CIA's Vaccine Ruse on Immunization in Pakistan." CEMFI Working Paper. https://dialnet.unirioja.es/servlet/articulo? codigo $=7726697$.

Nayar, Kuldip. 2013. Emergency Retold. Konark Publishers.

Nunn, Nathan. 2009. “The Importance of History for Economic Development.” Annu. Rev. Econ. 1 (1): 65-92.

—. 2014. "Historical Development.” Handbook of Economic Growth 2: 347-402.

Panandiker, V A Pai, R N Bishnoi, and Om Prakash Sharma. 1978. Family Planning Under the Emergency: Policy Implications of Incentives and Disincentives. New Delhi: Radiant 
medRxiv preprint doi: https://doi.org/10.1101/2021.01.21.21250216; this version posted August 11, 2021. The copyright holder for this preprint (which was not certified by peer review) is the author/funder, who has granted medRxiv a license to display the preprint in perpetuity.

Publishers.

Scott, Gemma. 2017. “"My Wife Had to Get Sterilised': Exploring Women's Experiences of Sterilisation under the Emergency in India, 1975--1977." Contemporary South Asia 25 (1): $70-84$.

Shah Commission of Inquiry. 1978. "Third and Final Report.” Government of India New Delhi.

Shrivastwa, Nijika, Brenda W Gillespie, Giselle E Kolenic, James M Lepkowski, and Matthew L Boulton. 2015. "Predictors of Vaccination in India for Children Aged 12--36 Months." American Journal of Preventive Medicine 49 (6): S435--S444.

Singh, Karan. 1976. "National Population Policy: A Statement of the Government of India." Population and Development Review 2 (2): 309-12.

Srivastava, Swati, Jasmine Fledderjohann, and Ashish Kumar Upadhyay. 2020. "Explaining Socioeconomic Inequalities in Immunisation Coverage in India: New Insights from the Fourth National Family Health Survey (2015--16).” BMC Pediatrics 20 (1): 1-12.

Tarlo, Emma. 2000. "Body and Space in a Time of Crisis: Sterilization and Resettlement during the Emergency in Delhi." Violence and Subjectivity, 242-70.

Vardhan, Harsh. 2021. "Dr Harsh Vardhan on Twitter: "There Is No Scientific Evidence to Suggest That \#COVIDVaccine Could Cause Infertility in Either Men or Women. Kindly Do Not Pay Heed to Such Rumours or Information from Unverified Sources.

\#StayInformedStaySafe @PMOIndia@MoH.”2021.

https://twitter.com/drharshvardhan/status/1349687664639762435?s=20.

Vicziany, Marika. 1982. "Coercion in a Soft State: The Family-Planning Program of India: Part I: The Myth of Voluntarism." Pacific Affairs 55 (3): 373-402.

WHO. 2020. "Immunization Agenda 2030: A Global Strategy to Leave No One Behind.” World Health Organinzation. https://www.who.int/teams/immunization-vaccines-andbiologicals/strategies/ia2030.

Williams, Rebecca Jane. 2014. "Storming the Citadels of Poverty: Family Planning under the Emergency in India, 1975-1977." The Journal of Asian Studies, 471-92. 
Figure 1: Total Number of Sterilizations Performed in India (1956-82)

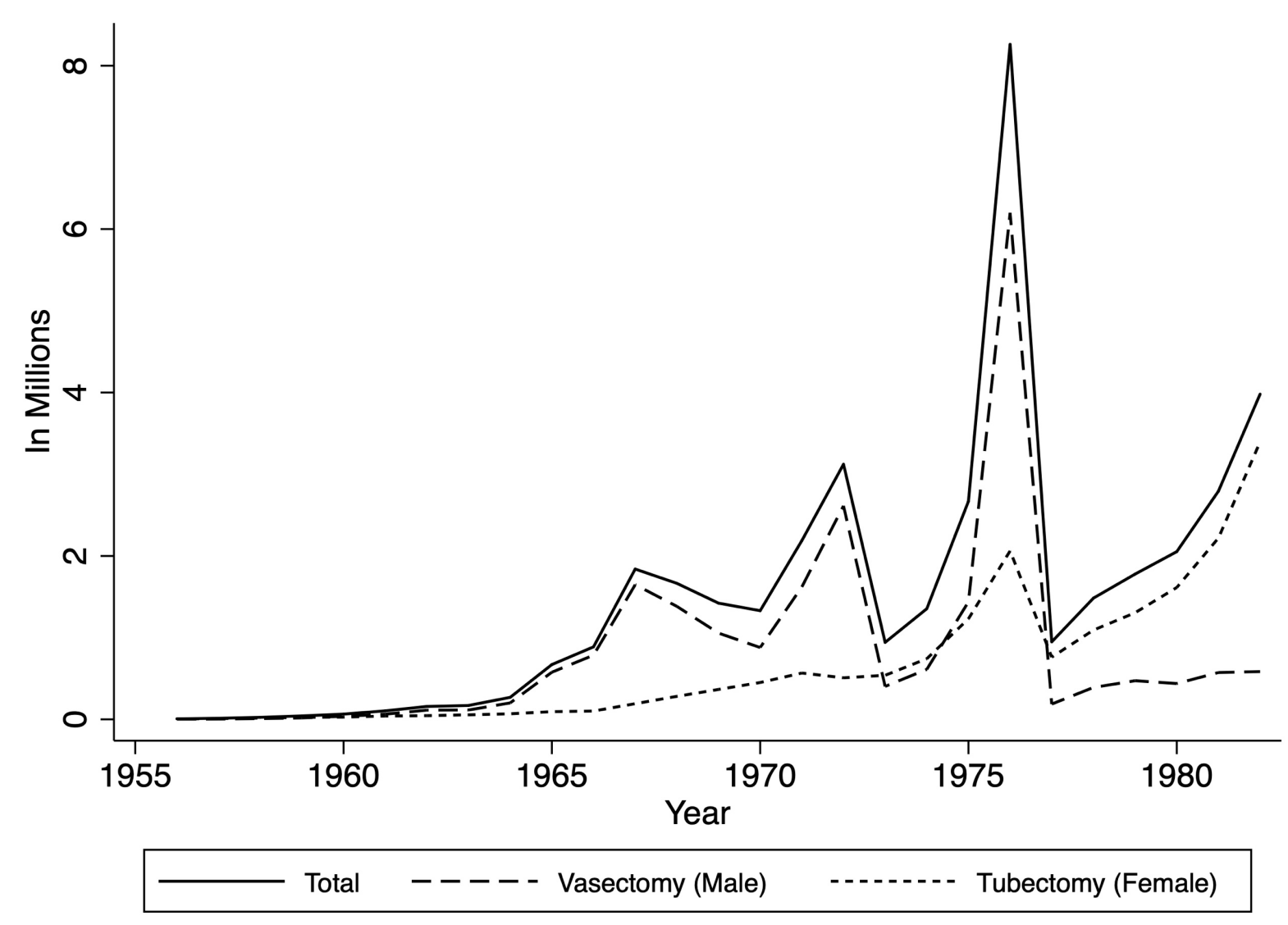

Notes: Figure 1 presents the total number of sterilizations along with the types of sterilization performed in India every year since the beginning of the program in 1956. The solid line represents the total number of sterilizations performed every year. The dashed and short dashed lines represent the total number of vasectomies and tubectomies performed every year, respectively. 
medRxiv preprint doi: https://doi.org/10.1101/2021.01.21.21250216; this version posted August 11, 2021. The copyright holder for this preprint (which was not certified by peer review) is the author/funder, who has granted medRxiv a license to display the preprint in perpetuity.

It is made available under a CC-BY-NC-ND 4.0 International license .

Figure 2: Excess Sterilizations Performed in 1976-77 (Normalized by 1975-76 Numbers)

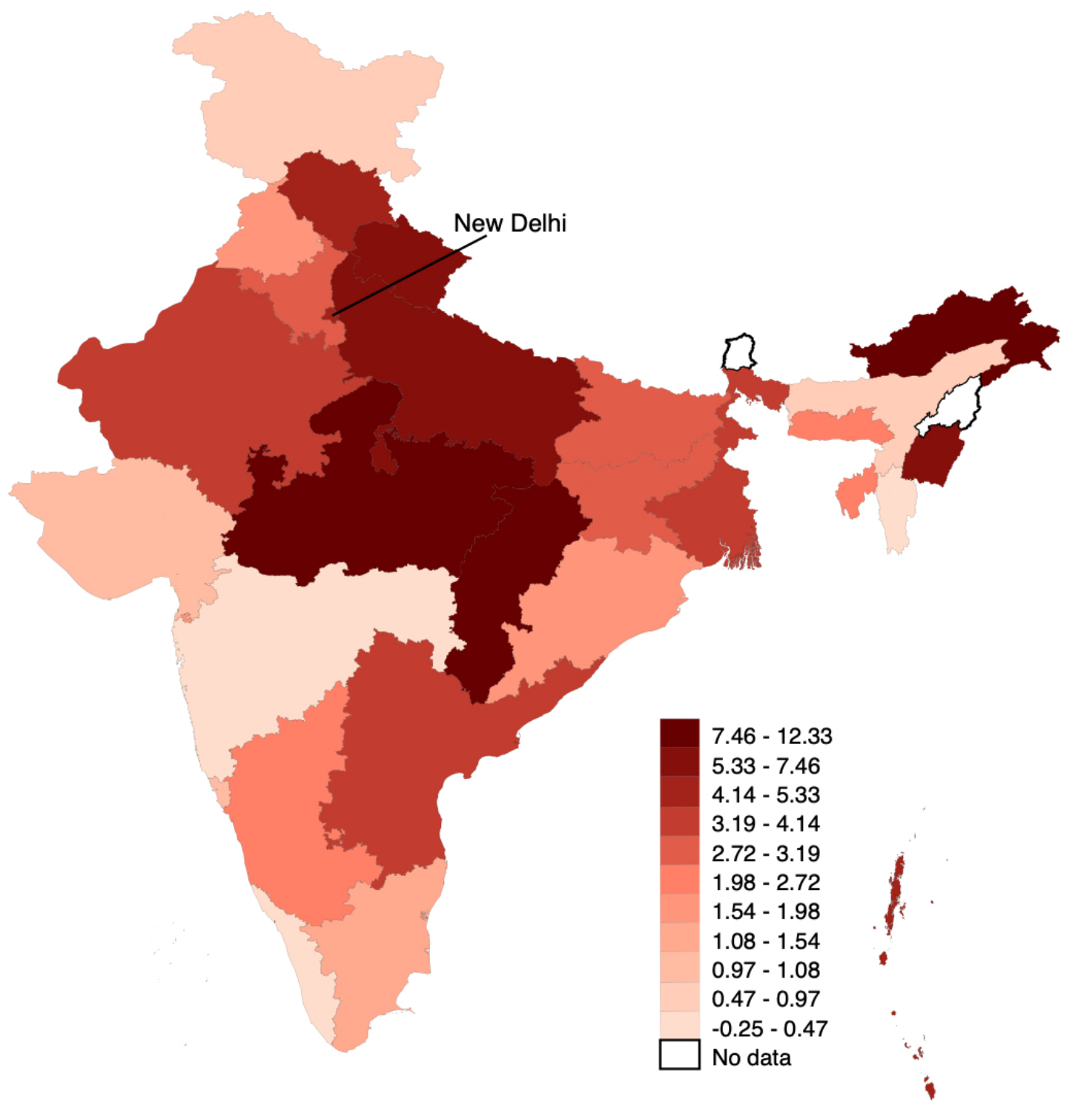

Notes: Figure 2 presents the state-level variation in exposure to the forced sterilization policy as measured by the number of excess sterilizations performed in 1976-77 normalized by performance in 1975-76. Darker shades denote a greater number of excess sterilizations performed. 
Figure 3: Correlation Plot for All Vaccination Index

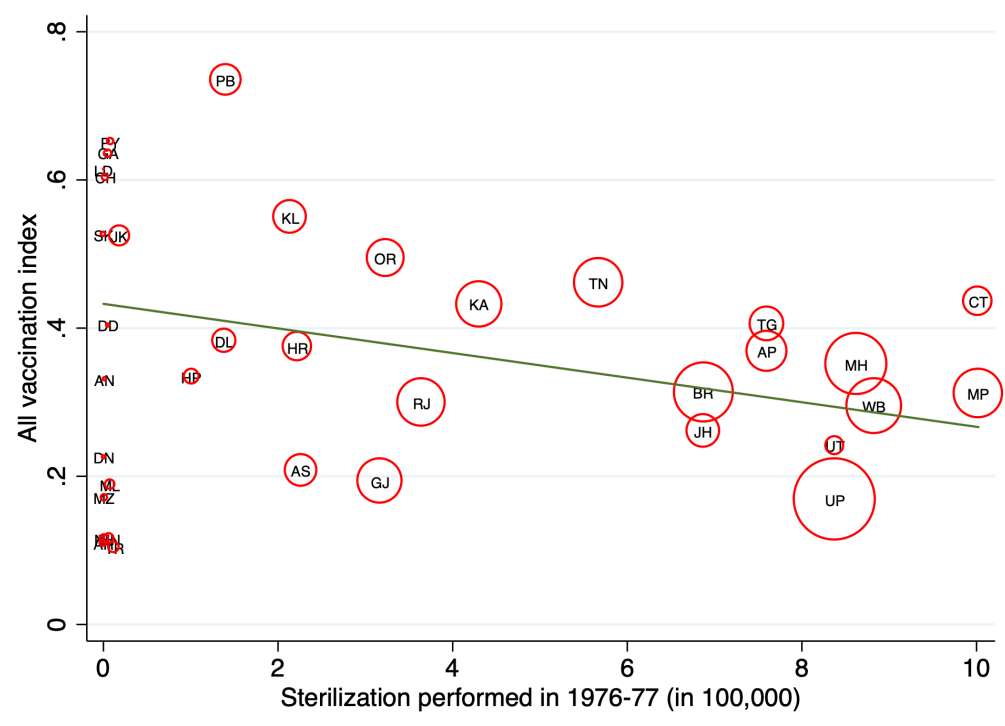

Panel A: Association between all vaccination index and total number of sterilizations performed in 1976-77

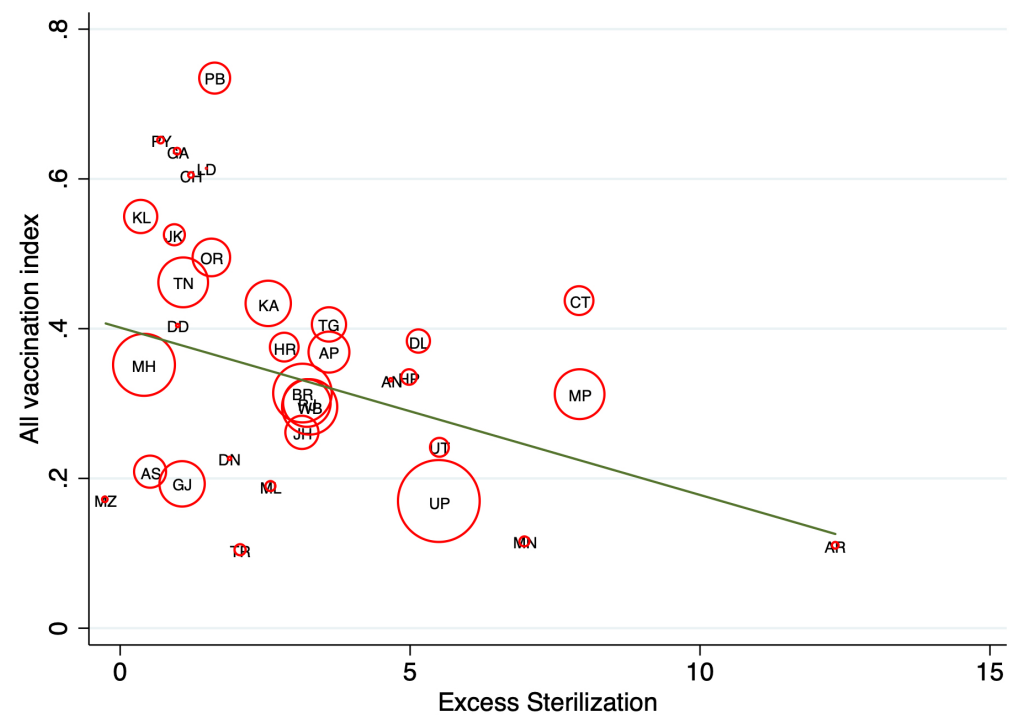

Panel B: Association between all vaccination index and excess sterilizations performed in 197677 normalized by 1975-76 figures

Notes: Figure 3 presents correlation plots of exposure to the forced sterilization policy and the allvaccination index in 2015-16. Panel A presents the correlation between the state-level total number of sterilizations performed in 1976-77 and the all-vaccination index in 2015-16. Panel B presents the correlation between state-level excess sterilizations performed in 1976-77 and the allvaccination index in 2015-16. The fitted lines are weighted by the population of the state and union territory. 
Figure 4: Distance from New Delhi as Instrument

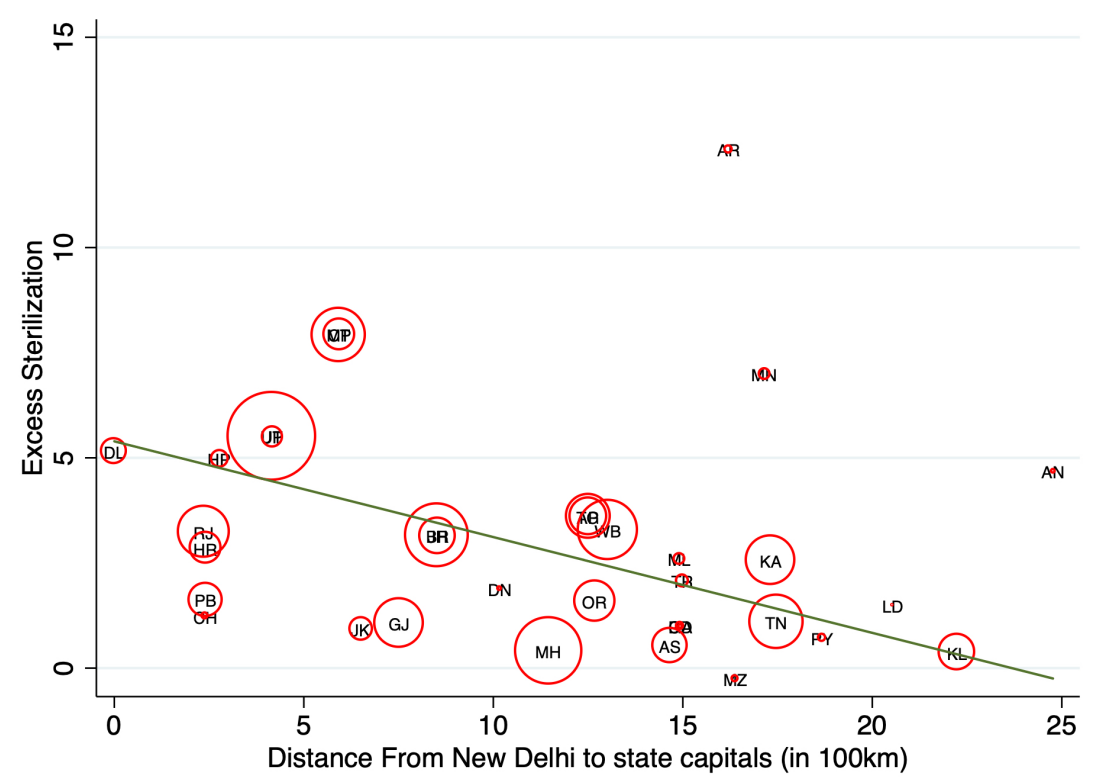

Panel A: Association between distance from New Delhi to state capitals (in $100 \mathrm{~km}$ ) and excess sterilization in 1976-77

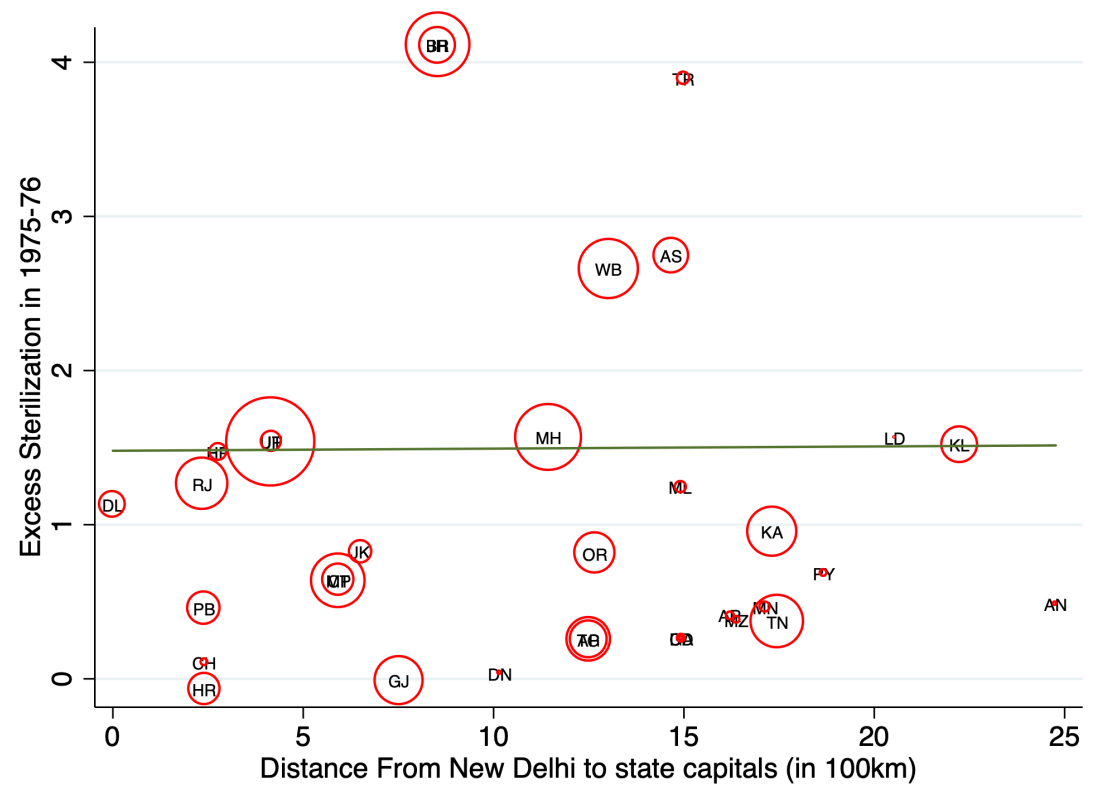

Panel B: Association between distance from New Delhi to state capitals (in $100 \mathrm{~km}$ ) and excess sterilization in 1975-76 (previous year).

Notes: Figure 4 presents strength and exogeneity of our instrument. Panel A presents the correlation between state-level excess sterilizations performed in 1976-77 and the distance from New Delhi to state capitals (in 100km). Panel B presents the correlation between state-level excess sterilizations performed in 1975-76 and the distance from New Delhi to state capitals (in 100km). The fitted lines are weighted by the population of the state and union territory. 
Figure 5: Heterogenous Effects

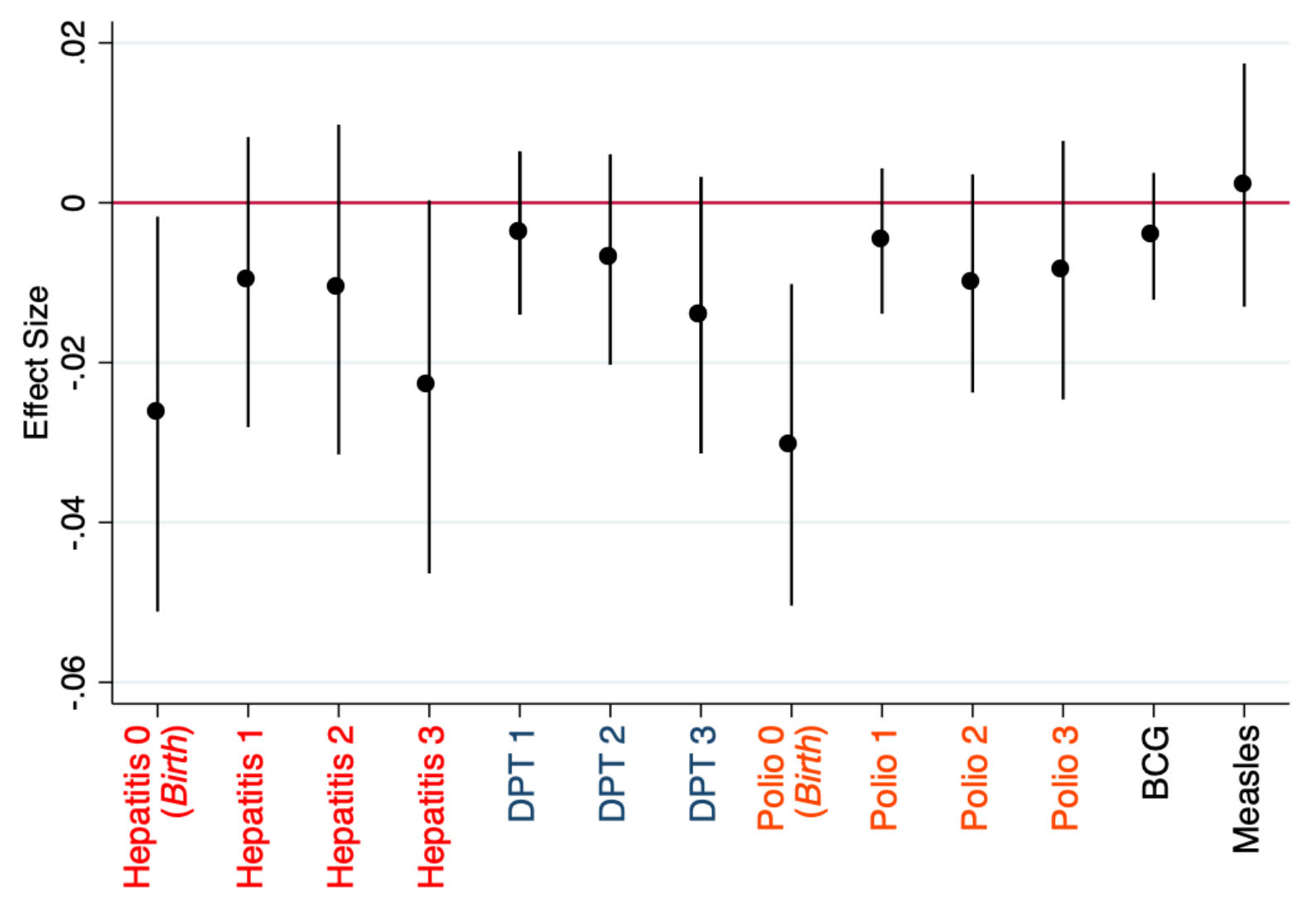

Notes: Figure 5 presents the regression coefficients of each vaccine. See Appendix Table E1 for more information on variable definitions and for the results in table format. 
Figure 6: Mechanism - Non-institutional Delivery

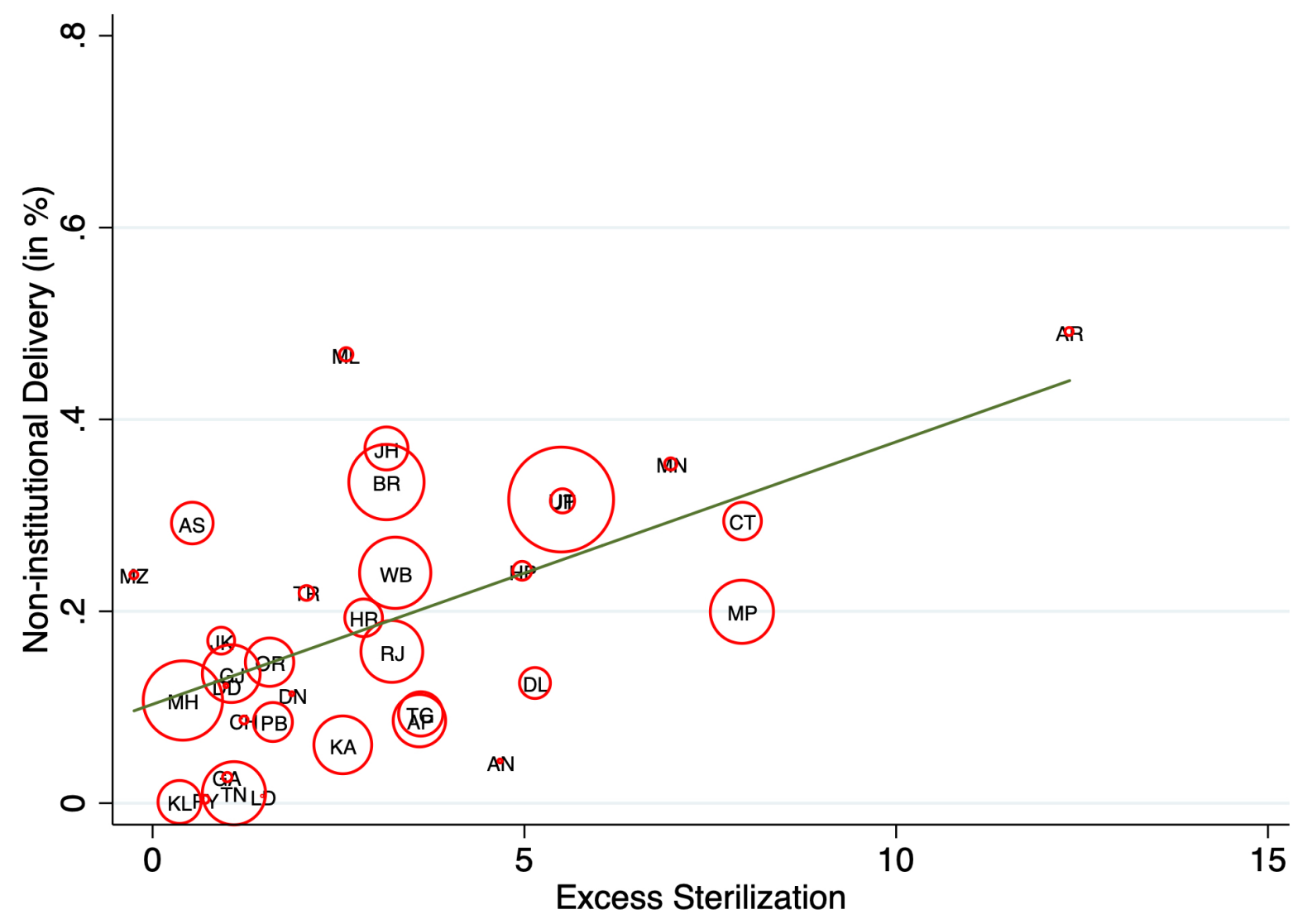

Notes: Figure 6 presents the association between state-level exposure to the forced sterilization policy and the percent of children who have had noninstitutional delivery. The fitted line is weighted by the population of the state and union territory. 
Figure 7: Mechanism - Reasons for Non-institutional Delivery

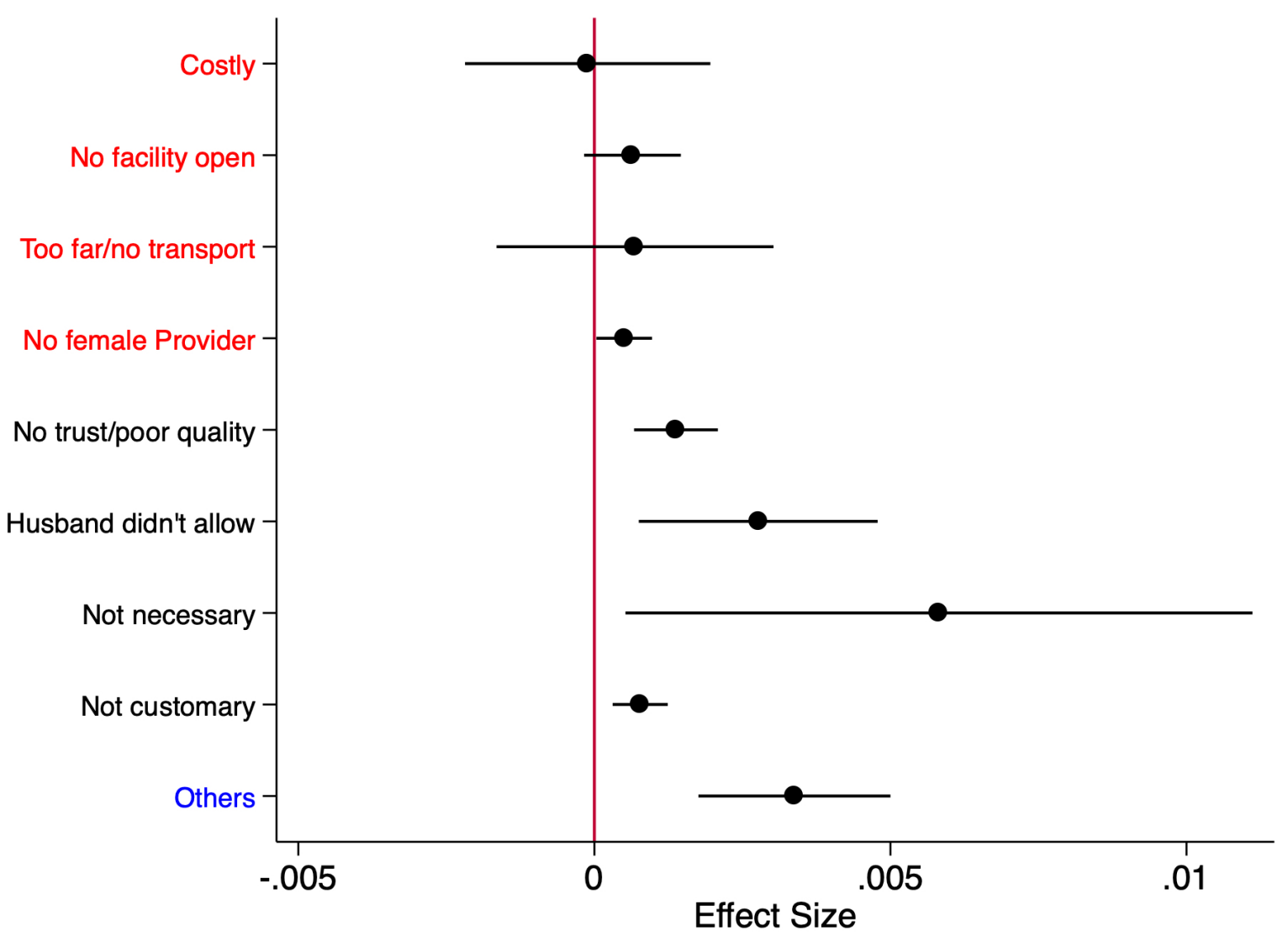

Notes: Figure 7 presents the regression coefficients of each reasons for noninstitutional delivery. See Appendix Table F2 for more information on variable definitions and for the results in table format. 
Figure 8: Mechanism - Antenatal Care (ANC)

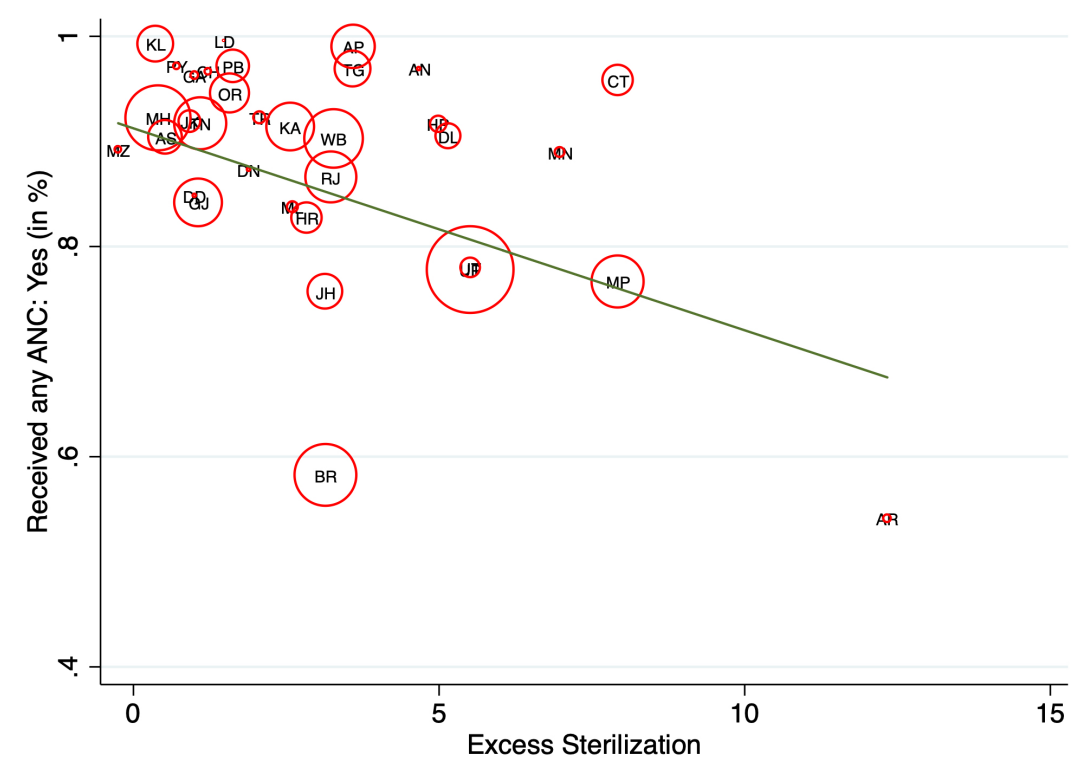

Panel A: Association between excess sterilization and the probability of receiving ANC

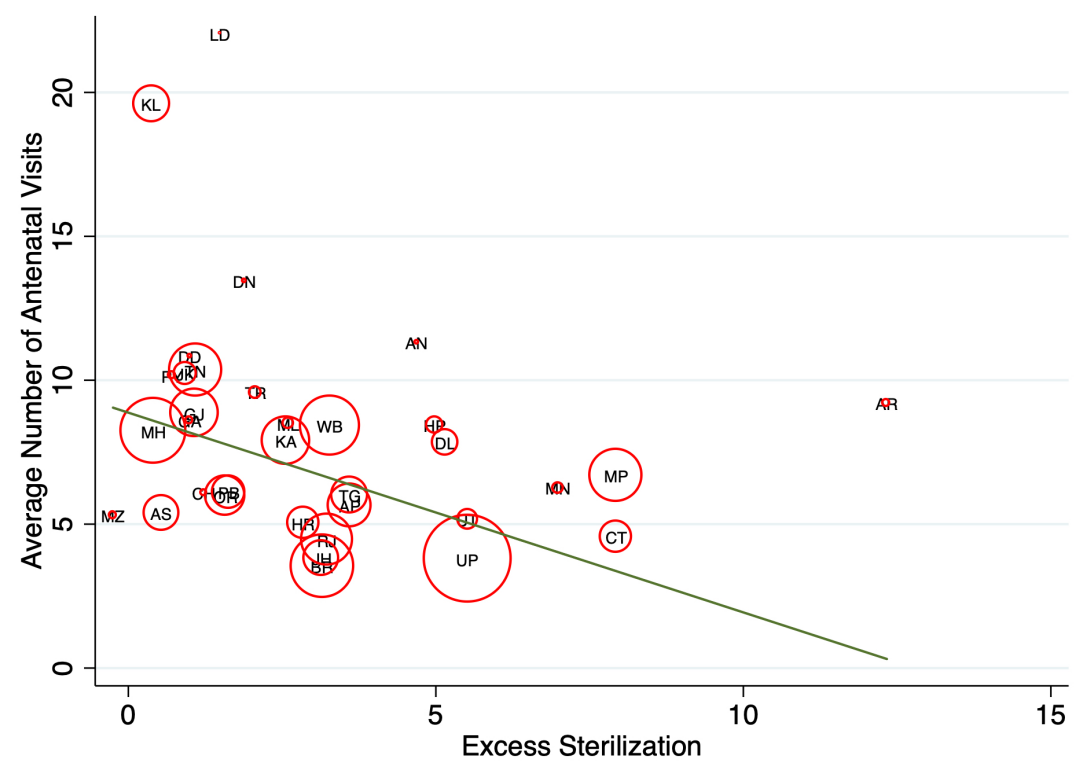

Panel B: Association between excess sterilization and the number of visits conditional on receiving $\mathrm{ANC}$

Notes: Figure 8 presents the association between exposure to the forced sterilization policy on antenatal care (ANC). Panel A presents the association between state-level excess sterilizations performed in 1976-77 and the probability of receiving ANC. Panel B presents the correlation between state-level excess sterilizations performed in 1975-76 and the number of visits conditional on receiving any ANC. The fitted lines are weighted by the population of the state and union territory. 
Figure 9: Consequence - Child Mortality

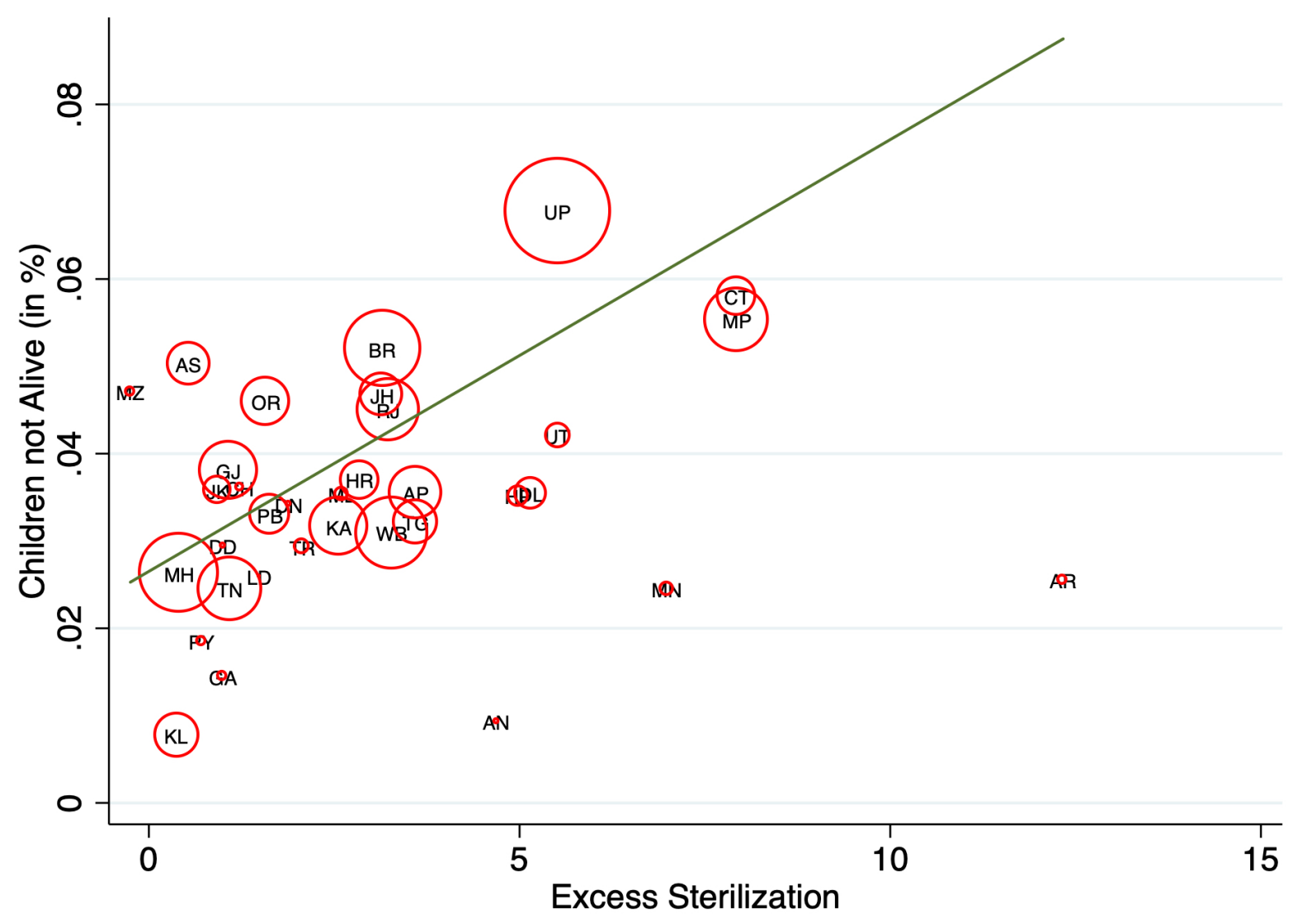

Notes: Figure 9 presents the association between the state-level exposure to the forced sterilization policy and the percent of children who are not alive. The fitted line is weighted by the population of the state and union territory. 
Table 1: OLS Estimates - Different Measures of Sterilization

\begin{tabular}{|c|c|c|c|c|c|}
\hline & \multicolumn{5}{|c|}{ Dependent variable: All Vaccination Index } \\
\hline & $(1)$ & $(2)$ & (3) & (4) & (5) \\
\hline $\begin{array}{l}\text { Total Sterilizations Performed in 1976-77 } \\
\text { (in } 100,000 \text { ) }\end{array}$ & $\begin{array}{c}-0.00843^{* * *} \\
(0.00107)\end{array}$ & & & & \\
\hline $\begin{array}{l}\text { Total Sterilizations Performed in 1976-77 } \\
\text { (in log) }\end{array}$ & & $\begin{array}{c}-0.00712 * * \\
(0.00317)\end{array}$ & & & \\
\hline $\begin{array}{l}\text { Excess Sterilization Performed in 1976- } \\
77 \text { (in 100,000) }\end{array}$ & & & $\begin{array}{r}-0.00827 * * * \\
(0.000983)\end{array}$ & & \\
\hline $\begin{array}{l}\text { Excess Sterilization Performed in 1976- } \\
77 \text { (in log) }\end{array}$ & & & & $\begin{array}{c}-0.0178 * * * \\
(0.00279)\end{array}$ & \\
\hline Excess Sterilization & & & & & $\begin{array}{c}-0.00860^{* * *} \\
(0.00102)\end{array}$ \\
\hline Individual Controls & YES & YES & YES & YES & YES \\
\hline Household Controls & YES & YES & YES & YES & YES \\
\hline Geographic Controls & YES & YES & YES & YES & YES \\
\hline Health Facility Controls & YES & YES & YES & YES & YES \\
\hline Observations & 231,984 & 231,984 & 226,991 & 222,393 & 226,991 \\
\hline Mean of Dependent Variable & 0.321 & 0.321 & 0.321 & 0.321 & 0.321 \\
\hline $\begin{array}{l}\text { Mean of Explanatory variable } \\
\text { (Sterilization measures) }\end{array}$ & 6.520471 & 13.21386 & 4.704912 & 12.82287 & 3.452456 \\
\hline
\end{tabular}

Notes: Data are from India's National Family and Health Survey 2015-16 (NFHS-4). The unit of observation is a child below the age of 5. All vaccinations include BCG, measles, and three doses each of DPT, polio vaccine including polio vaccine given at birth, and four doses of hepatitis B. Total Sterilizations Performed in 1976-77 (in 100,000) measures the total number of sterilizations performed in a state in 1976-77 (expressed in 100,000 individuals). Total Sterilizations Performed in 1976-77 (in $\log$ ) measures the natural $\log$ of the number of sterilizations performed in 1976-77. Excess Sterilization Performed in 1976-77 (in 100,000) measures the number of excess sterilizations performed in 1976-77 over and above the 1975-76 numbers (expressed in 100,000 individuals). Excess Sterilization Performed in 1976-77 (in log) measures the natural log of the excess number of sterilizations performed in 1976-77 over and above the 1975-76 numbers. Excess Sterilization measures the number of excess sterilizations performed in 1976-77 (compared with 1975-76 numbers) normalized by the sterilization performed in 1975-76 at the state level. Individual controls are for a gender indicator variable of the child, month by year of birth fixed effects, an indicator for whether the child is twin, and birth order of the child. Household controls include age and sex of the household head, household size, number of household members below the age 5, seven religion fixed effects, four caste fixed effects, 20 education of the mother fixed effects, four household wealth index fixed effects, and an indicator for whether any household member is covered by health insurance. Geographic controls include altitude of the cluster in meters, altitude squared, state-level population density per square kilometers (in log), and an indicator of whether the place of residence is urban. Health facility controls include hospital per 1000 population and doctors per 1000 population at the state level. Robust standard errors in parentheses clustered at the NFHS-4 cluster (PSU) level. ${ }^{* *} \mathrm{p}<0.01,{ }^{* *} \mathrm{p}<0.05,{ }^{*} \mathrm{p}<0.1$ 
medRxiv preprint doi: https://doi.org/10.1101/2021.01.21.21250216; this version posted August 11, 2021. The copyright holder for this preprint (which was not certified by peer review) is the author/funder, who has granted medRxiv a license to display the preprint in perpetuity.

It is made available under a CC-BY-NC-ND 4.0 International license .

Table 2: OLS Estimates - Different Measures of Vaccination

\begin{tabular}{lccc}
\hline \hline Dependent variables: & $\begin{array}{c}\text { Basic } \\
\text { Vaccination } \\
\text { Index } \\
(1)\end{array}$ & $\begin{array}{c}\text { Appropriate } \\
\text { Vaccination } \\
\text { Index } \\
(2)\end{array}$ & $\begin{array}{c}\text { All Vaccination } \\
\text { Index }\end{array}$ \\
& $-0.00289^{* * *}$ & $-0.00843^{* * *}$ & $-0.00860^{* * *}$ \\
& $(0.000924)$ & $(0.00102)$ & $(0.00102)$ \\
Excess Sterilization & YES & YES & YES \\
Individual Controls & YES & YES & YES \\
Household Controls & YES & YES & YES \\
Geographic Controls & YES & YES & YES \\
Health Facility Controls & & & \\
& 229,287 & 226,991 & 226,991 \\
Observations & 0.505 & 0.324 & 0.321 \\
Mean of Dependent Variable & 3.452456 & 3.446676 & 3.446676 \\
Mean of Excess Sterilization &
\end{tabular}

Notes: Data are from India's National Family and Health Survey 2015-16 (NFHS-4).

The unit of observation is a child below the age of 5 . Basic vaccinations include BCG, measles, and three doses each of DPT and polio vaccine (excluding polio vaccine given at birth). Appropriate vaccinations include all basic vaccinations plus four doses of hepatitis B. All vaccinations include all appropriate vaccination plus polio vaccine given at birth. Excess Sterilization measures the number of excess sterilizations performed in 1976-77 (compared with 1975-76 numbers) normalized by the sterilization performed in 1975-76 at the state level. Individual controls are for a gender indicator variable of the child, month by year of birth fixed effects, an indicator for whether the child is twin, and birth order of the child. Household controls include age and sex of the household head, household size, number of household members below the age 5 , seven religion fixed effects, four caste fixed effects, 20 education of the mother fixed effects, four household wealth index fixed effects, and an indicator for whether any household member is covered by health insurance. Geographic controls include altitude of the cluster in meters, altitude squared, state-level population density per square kilometers (in $\log$ ), and an indicator of whether the place of residence is urban. Health facility controls include hospital per 1000 population and doctors per 1000 population at the state level. Robust standard errors in parentheses clustered at the NFHS-4 cluster (PSU) level. $* * * \mathrm{p}<0.01,{ }^{* *} \mathrm{p}<0.05,{ }^{*} \mathrm{p}<0.1$ 
Table 3: IV Estimates

\begin{tabular}{|c|c|c|c|}
\hline & \multirow{2}{*}{\multicolumn{3}{|c|}{$\begin{array}{c}\text { Panel A: First Stage Estimates } \\
\text { Dependent variable: Excess Sterilization }\end{array}$}} \\
\hline & & & \\
\hline \multirow[t]{5}{*}{ Distance from New Delhi (in 100km) } & -0.246 & -0.246 & -0.246 \\
\hline & $(0.00236)$ & $(0.00236)$ & $(0.00236)$ \\
\hline & {$[0.0125]$} & {$[0.0125]$} & {$[0.0125]$} \\
\hline & $\{0.0619\}$ & $\{0.0619\}$ & $\{0.0619\}$ \\
\hline & $((0.0158))$ & $((0.0158))$ & $((0.0158))$ \\
\hline \multirow{4}{*}{ Dependent variables: } & \multicolumn{3}{|c|}{ Panel B: Second Stage Estimates } \\
\hline & Basic & Appropriate & All \\
\hline & Vaccination & Vaccination & Vaccination \\
\hline & $\begin{array}{l}\text { Index } \\
(1)\end{array}$ & $\begin{array}{l}\text { Index } \\
(2)\end{array}$ & $\begin{array}{c}\text { Index } \\
(3)\end{array}$ \\
\hline \multirow[t]{5}{*}{ Excess Sterilization } & -0.00996 & -0.0232 & -0.0236 \\
\hline & $(0.00189)$ & $(0.00229)$ & $(0.00231)$ \\
\hline & [0.00449] & {$[0.00518]$} & {$[0.00525]$} \\
\hline & $\{0.00965\}$ & $\{0.0111\}$ & $\{0.0112\}$ \\
\hline & $((0.00529))$ & $((0.00548))$ & $((0.00554))$ \\
\hline Individual Controls & YES & YES & YES \\
\hline Household Controls & YES & YES & YES \\
\hline Geographic Controls & YES & YES & YES \\
\hline Health Facility Controls & YES & YES & YES \\
\hline Observations & 229,287 & 226,991 & 226,991 \\
\hline F Stat of Excluded Instrument & 15.77 & 15.75 & 15.75 \\
\hline Mean of Dependent Variable & 0.505 & 0.324 & 0.321 \\
\hline Mean of Excess Sterilization & 3.452 & 3.447 & 3.447 \\
\hline
\end{tabular}

Notes: Data are from India's National Family and Health Survey 2015-16 (NFHS-4). The unit of observation is a child below the age of 5 . Basic vaccinations include BCG, measles, and three doses each of DPT and polio vaccine (excluding polio vaccine given at birth). Appropriate vaccinations include all basic vaccinations plus four doses of hepatitis B. All vaccinations include all appropriate vaccination plus polio vaccine given at birth. Excess Sterilization measures the number of excess sterilizations performed in 1976-77 (compared with 1975-76 numbers) normalized by the sterilization performed in 1975-76 at the state level. Individual controls are for a gender indicator variable of the child, month by year of birth fixed effects, an indicator for whether the child is twin, and birth order of the child. Household controls include age and sex of the household head, household size, number of household members below the age 5, seven religion fixed effects, four caste fixed effects, 20 education of the mother fixed effects, four household wealth index fixed effects, and an indicator for whether any household member is covered by health insurance. Geographic controls include altitude of the cluster in meters, altitude squared, state-level population density per square kilometers (in log), and an indicator of whether the place of residence is urban. Health facility controls include hospital per 1000 population and doctors per 1000 population at the state level. Below each coefficient four standard errors are reported. The first, reported in parentheses, is standard errors adjusted for clustering at the NFHS-4 cluster (PSU) level. The second, reported in square brackets, is standard errors adjusted for clustering at the current district level. The third, reported in curly brackets, is standard errors adjusted for clustering at the current state level. The fourth, reported in double parenthesis, is standard errors adjusted for spatial correction proposed by Conley (1999). The reported F Statistics of Excluded Instrument is based on adjusting standard errors for clustering at the state-level. 
Table 4: Test of Exogeneity of the Instrument

\begin{tabular}{|c|c|c|c|c|c|c|}
\hline \multirow[b]{2}{*}{ Dependent variables: } & \multicolumn{6}{|c|}{ Panel A: First Stage Estimates } \\
\hline & \multicolumn{3}{|c|}{ Excess Sterilization in 1975-76 } & \multicolumn{3}{|c|}{ Excess Female Sterilization (Tubectomy) } \\
\hline \multirow{2}{*}{$\begin{array}{l}\text { Distance from New Delhi (in } \\
100 \mathrm{~km} \text { ) }\end{array}$} & -0.0115 & -0.0116 & -0.0116 & 0.0153 & 0.0153 & 0.0153 \\
\hline & $(0.0270)$ & $(0.0269)$ & $(0.0269)$ & $(0.0123)$ & $(0.0123)$ & $(0.0123)$ \\
\hline \multirow[b]{2}{*}{ Dependent variables: } & \multicolumn{6}{|c|}{ Panel B: Second Stage Estimates } \\
\hline & $\begin{array}{c}\text { Basic } \\
\text { Vaccinati } \\
\text { on } \\
\text { Index } \\
(1)\end{array}$ & $\begin{array}{c}\text { Appropriate } \\
\text { Vaccination } \\
\text { Index } \\
(2)\end{array}$ & $\begin{array}{c}\text { All } \\
\text { Vaccination } \\
\text { Index } \\
(3)\end{array}$ & $\begin{array}{c}\text { Basic } \\
\text { Vaccination } \\
\text { Index } \\
(4)\end{array}$ & $\begin{array}{c}\text { Appropriate } \\
\text { Vaccination } \\
\text { Index } \\
(5)\end{array}$ & $\begin{array}{c}\text { All } \\
\text { Vaccination } \\
\text { Index } \\
(6)\end{array}$ \\
\hline \multirow[t]{2}{*}{ Excess Sterilization in $1975-76$} & -0.213 & -0.492 & -0.501 & & & \\
\hline & $(0.489)$ & $(1.058)$ & $(1.075)$ & & & \\
\hline \multirow{2}{*}{$\begin{array}{l}\text { Excess Female Sterilization } \\
\text { (Tubectomy) }\end{array}$} & & & & 0.160 & 0.372 & 0.379 \\
\hline & & & & $(0.195)$ & $(0.341)$ & $(0.347)$ \\
\hline Individual Controls & YES & YES & YES & YES & YES & YES \\
\hline ousehold Controls & YES & YES & YES & YES & YES & YES \\
\hline G & YES & YES & YES & YES & YES & YES \\
\hline Health Facility Controls & YES & YES & YES & YES & YES & YES \\
\hline bservations & 229,287 & 226,991 & 226,991 & 228,992 & 226,696 & 226,696 \\
\hline F Stat of Excluded Instrument & 0.180 & 0.190 & 0.190 & 1.560 & 1.560 & 1.560 \\
\hline Mean of Dependent Variable & 0.505 & 0.324 & 0.321 & 0.505 & 0.324 & 0.321 \\
\hline $\begin{array}{l}\text { Mean of Excess Sterilization in } \\
1975-76\end{array}$ & 1.597 & 1.595 & 1.595 & & & \\
\hline $\begin{array}{l}\text { Mean of Excess Female } \\
\text { Sterilization (Tubectomy) }\end{array}$ & & & & 0.786 & 0.786 & 0.786 \\
\hline \multicolumn{7}{|c|}{$\begin{array}{l}\text { Notes: Data are from India's National Family and Health Survey 2015-16 (NFHS-4). The unit of observation is a child below the } \\
\text { age of 5. Basic vaccinations include BCG, measles, and three doses each of DPT and polio vaccine (excluding polio vaccine } \\
\text { given at birth). Appropriate vaccinations include all basic vaccinations plus four doses of hepatitis B. All vaccinations include all } \\
\text { appropriate vaccination plus polio vaccine given at birth. Excess Sterilization n } 1975-76 \text { measures the number of excess } \\
\text { sterilizations performed in 1975-76 (compared with 1974-75 numbers) normalized by the sterilization performed in } 1974-75 \text { at } \\
\text { the state level. Excess Female Sterilization (Tubectomy) measures the number of excess tubectomies performed in } 1976-77 \\
\text { (compared with } 1975-76 \text { numbers) normalized by the number of tubectomies performed in } 1975-76 \text { at the state level. Individual } \\
\text { controls are for a gender indicator variable of the child, month by year of birth fixed effects, an indicator for whether the child is } \\
\text { twin, and birth order of the child. Household controls include age and sex of the household head, household size, number of } \\
\text { household members below the age 5, seven religion fixed effects, four caste fixed effects, } 20 \text { education of the mother fixed effects, } \\
\text { four household wealth index fixed effects, and an indicator for whether any household member is covered by health insurance. } \\
\text { Geographic controls include altitude of the cluster in meters, altitude squared, state-level population density per square kilometers } \\
\text { (in log), and an indicator of whether the place of residence is urban. Health facility controls include hospital per } 1000 \text { population } \\
\text { and doctors per } 1000 \text { population at the state level. The reported F Statistics of Excluded Instrument is based on adjusting standard } \\
\text { errors for clustering at the state-level. Robust standard errors in parentheses clustered at the state level. } * * * \text { p }<0.01, * * p<0.05, * \text { p }<0.1\end{array}$} \\
\hline
\end{tabular}


medRxiv preprint doi: https://doi.org/10.1101/2021.01.21.21250216; this version posted August 11, 2021. The copyright holder for this preprint (which was not certified by peer review) is the author/funder, who has granted medRxiv a license to display the preprint in perpetuity.

It is made available under a CC-BY-NC-ND 4.0 International license .

Table 5: Mechanism - Non-Institutional Delivery

\begin{tabular}{|c|c|c|c|c|c|}
\hline & \multicolumn{5}{|c|}{ Dependent variable: Non-institutional Delivery } \\
\hline & $(1)$ & (2) & (3) & (4) & $(5)$ \\
\hline Excess Sterilization & $\begin{array}{c}0.0479 * * * \\
(0.0146)\end{array}$ & $\begin{array}{c}0.0366^{* * *} \\
(0.0134)\end{array}$ & $\begin{array}{l}0.0254 * * * \\
(0.00823)\end{array}$ & $\begin{array}{c}0.0249 * * * \\
(0.00711)\end{array}$ & $\begin{array}{l}0.0292^{* * * *} \\
(0.00699)\end{array}$ \\
\hline Individual Controls & NO & YES & YES & YES & YES \\
\hline Household Controls & NO & NO & YES & YES & YES \\
\hline Geographic Controls & NO & NO & NO & YES & YES \\
\hline Health Facility Controls & NO & NO & NO & NO & YES \\
\hline Observations & 242,328 & 242,328 & 232,943 & 232,481 & 232,481 \\
\hline $\begin{array}{l}\text { Mean of Dependent } \\
\text { Variable }\end{array}$ & 0.204 & 0.204 & 0.203 & 0.203 & 0.203 \\
\hline
\end{tabular}

Notes: Data are from India's National Family and Health Survey 2015-16 (NFHS-4). The unit of observation is a child below the age of 5. Non-institutional Delivery is an indicator variable for a child born at home in the NFHS4 data. Excess Sterilization measures the number of excess sterilizations performed in 1976-77 (compared with 1975-76 numbers) normalized by the sterilization performed in 1975-76 at the state level. Individual controls are for a gender indicator variable of the child, month by year of birth fixed effects, an indicator for whether the child is twin, and birth order of the child. Household controls include age and sex of the household head, household size, number of household members below the age 5, seven religion fixed effects, four caste fixed effects, 20 education of the mother fixed effects, four household wealth index fixed effects, and an indicator for whether any household member is covered by health insurance. Geographic controls include altitude of the cluster in meters, altitude squared, state-level population density per square kilometers (in log), and an indicator of whether the place of residence is urban. Health facility controls include hospital per 1000 population and doctors per 1000 population at the state level. Robust standard errors in parentheses clustered at the state level. ${ }^{* * *} \mathrm{p}<0.01,{ }^{* *} \mathrm{p}<0.05,{ }^{*} \mathrm{p}<0.1$ 
medRxiv preprint doi: https://doi.org/10.1101/2021.01.21.21250216; this version posted August 11, 2021. The copyright holder for this preprint (which was not certified by peer review) is the author/funder, who has granted medRxiv a license to display the preprint in perpetuity.

It is made available under a CC-BY-NC-ND 4.0 International license .

Table 6: Mechanism - Antenatal Care (ANC)

\begin{tabular}{lcc}
\hline \hline Dependent variables: & $\begin{array}{c}\text { Received any } \\
\text { Antenatal Care } \\
(1)\end{array}$ & $\begin{array}{c}\text { Number of Visits } \\
\text { Excess Sterilization }\end{array}$ \\
& $-0.0198^{* *}$ & $-1.282^{* * *}$ \\
& $(0.00843)$ & $(0.329)$ \\
Individual Controls & YES & YES \\
Household Controls & YES & YES \\
Geographic Controls & YES & YES \\
Health Facility Controls & YES & YES \\
Observations & 177,040 & 146,167 \\
Mean of Dependent Variable & 0.832 & 5.685 \\
\hline
\end{tabular}

Notes: Data are from India's National Family and Health Survey 2015-16 (NFHS-4). The unit of observation is a mother. Received Antenatal Care is an indicator variable for mothers who received antenatal care in the last pregnancy in the NFHS-4 data. Number of Visits measures the number of times the mother received antenatal care conditional on receiving any antenatal care in the last pregnancy. Excess Sterilization measures the number of excess sterilizations performed in 1976-77 (compared with 197576 numbers) normalized by the sterilization performed in 1975-76 at the state level. Individual controls are for a gender indicator variable of the child, month by year of birth fixed effects, an indicator for whether the child is twin, and birth order of the child. Household controls include age and sex of the household head, household size, number of household members below the age 5 , seven religion fixed effects, four caste fixed effects, 20 education of the mother fixed effects, four household wealth index fixed effects, and an indicator for whether any household member is covered by health insurance. Geographic controls include altitude of the cluster in meters, altitude squared, state-level population density per square kilometers (in $\log$ ), and an indicator of whether the place of residence is urban. Health facility controls include hospital per 1000 population and doctors per 1000 population at the state level. Robust standard errors in parentheses clustered at the state level. ${ }^{* * *} \mathrm{p}<0.01,{ }^{* *} \mathrm{p}<0.05,{ }^{*} \mathrm{p}<0.1$ 
Table 7: Consequence - Child Mortality

\begin{tabular}{lccccc}
\hline \hline & $(1)$ & \multicolumn{5}{c}{ Dependent variable: Child is not Alive } & $(2)$ & $(3)$ & $(4)$ & $(5)$ \\
\hline & & & & & \\
Excess Sterilization & $0.00885^{* * *}$ & $0.00832^{* * *}$ & $0.00802^{* * *}$ & $0.00795^{* * *}$ & $0.00790^{* * *}$ \\
& $(0.00186)$ & $(0.00175)$ & $(0.00169)$ & $(0.00165)$ & $(0.00168)$ \\
Baseline Controls & NO & YES & YES & YES & YES \\
$\begin{array}{l}\text { Household Controls } \\
\text { Geographic Controls }\end{array}$ & NO & NO & YES & YES & YES \\
$\begin{array}{l}\text { Health Facility } \\
\text { Controls }\end{array}$ & NO & NO & NO & YES & YES \\
$\begin{array}{l}\text { Observations } \\
\begin{array}{l}\text { Mean of dependent } \\
\text { variable }\end{array}\end{array}$ & 254,015 & 254,015 & NO & NO & YES \\
\hline
\end{tabular}

Notes: Data are from India's National Family and Health Survey 2015-16 (NFHS-4). The unit of observation is a child below the age of 5 including who are not alive. Excess Sterilization measures the number of excess sterilizations performed in 1976-77 (compared with 1975-76 numbers) normalized by the sterilization performed in 1975-76 at the state level. Individual controls are for a gender indicator variable of the child, month by year of birth fixed effects, an indicator for whether the child is twin, and birth order of the child. Household controls include age and sex of the household head, household size, number of household members below the age 5, seven religion fixed effects, four caste fixed effects, 20 education of the mother fixed effects, four household wealth index fixed effects, and an indicator for whether any household member is covered by health insurance. Geographic controls include altitude of the cluster in meters, altitude squared, state-level population density per square kilometers (in $\log$ ), and an indicator of whether the place of residence is urban. Health facility controls include hospital per 1000 population and doctors per 1000 population at the state level. Robust standard errors in parentheses clustered at the state level. $* * * \mathrm{p}<0.01$, $* * \mathrm{p}<0.05, * \mathrm{p}<0.1$ 
medRxiv preprint doi: https://doi.org/10.1101/2021.01.21.21250216; this version posted August 11, 2021. The copyright holder for this preprint (which was not certified by peer review) is the author/funder, who has granted medRxiv a license to display the preprint in perpetuity.

It is made available under a CC-BY-NC-ND 4.0 International license.

\section{Online Appendix for}

Why is the Vaccination Rate Low in India?

Pramod Kumar Sur

Asian Growth Research Institute (AGI) and Osaka University 
medRxiv preprint doi: https://doi.org/10.1101/2021.01.21.21250216; this version posted August 11, 2021. The copyright holder for this preprint (which was not certified by peer review) is the author/funder, who has granted medRxiv a license to display the preprint in perpetuity.

It is made available under a CC-BY-NC-ND 4.0 International license .

\section{$\underline{\text { Section A: Figures }}$}

This section presents the figures. Figure A1 presents the vaccination completion rate for children between 12-23 months by their background characteristics. Figure A2 presents the examples of the archival data used in this paper. Figure A3 presents the state-level total number of sterilizations performed in 1975-76. Figure A4 presents the state-level total number of sterilizations performed in 1976-77. Figure A5 presents the correlation plot for basic vaccination Index. Figure A6 presents the correlation plot for appropriate vaccination Index.

Figure A1: Vaccination Completion Rate by Child's Background Characteristics (aged 12-23 months)
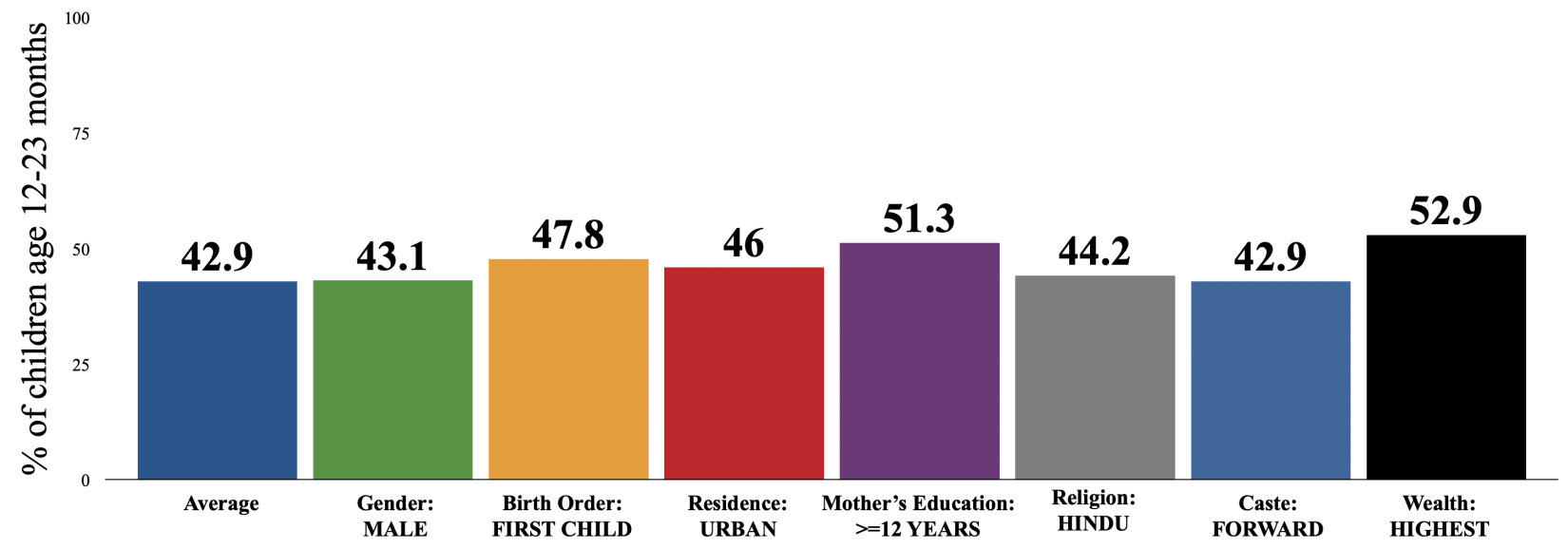

Notes: Author's compilation using data from National Family Health Survey (NFHS-4), 201516: India. These estimates are based on 12 reported vaccines (excluding Polio given at birth) for children between 12-23 months of age. See https://dhsprogram. com/pubs/pdf/FR339/FR339.pdf for details. 
Figure A2: Examples of Archival Records

\begin{tabular}{|c|c|c|c|c|}
\hline \multirow{2}{*}{$\begin{array}{r}\text { Year } \\
1 \\
\end{array}$} & $\frac{\text { Mur }}{\text { Vasectomy }}$ & $\frac{\text { er of Sterillis }}{\text { Tubectomy }}$ & ${ }_{\text {ons }}$ Total & $\begin{array}{l}\text { Percentage } \\
\text { of tubectomies } \\
\text { to total }\end{array}$ \\
\hline & 2 & 3 & 4 & 5 \\
\hline $\begin{array}{l}1956 \\
1957 \\
1958 \\
1959 \\
1960\end{array}$ & $\begin{array}{r}2,395 \\
4,152 \\
9,189 \\
17,633 \\
37,596\end{array}$ & $\begin{array}{r}4,758 \\
9,584 \\
15,959 \\
24,669 \\
26,742\end{array}$ & $\begin{array}{r}7,153 \\
13,736 \\
25,148 \\
42,302 \\
64,338\end{array}$ & $\begin{array}{l}66.5 \\
69.8 \\
63.5 \\
58.3 \\
41.6\end{array}$ \\
\hline $\begin{array}{l}1961 \\
1962 \\
1963 \\
1964 \\
1965 \text { January to } \\
\text { March 1966 }\end{array}$ & $\begin{array}{r}63,880 \\
112,357 \\
114,621 \\
201,171 \\
576,609\end{array}$ & $\begin{array}{l}40,705 \\
45,590 \\
55,625 \\
68,394 \\
94,214\end{array}$ & $\begin{array}{l}104,585 \\
157,947 \\
170,246 \\
269,565 \\
670,823\end{array}$ & $\begin{array}{l}38.9 \\
28.9 \\
32.7 \\
25.4 \\
14.0\end{array}$ \\
\hline $\begin{array}{l}1966-67 \\
1967-68 \\
1968-69 \\
1969-70 \\
1970-71\end{array}$ & $\begin{array}{r}785,378 \\
1,648,152 \\
1,383,053 \\
1,055,860 \\
878,800\end{array}$ & $\begin{array}{l}101,990 \\
191,659 \\
281,764 \\
366,258 \\
451,114\end{array}$ & $\begin{array}{r}887,368 \\
1,839,811 \\
1,664,817 \\
1,422,118 \\
1,329,914\end{array}$ & $\begin{array}{l}11.5 \\
10.4 \\
16.9 \\
25.8 \\
33.9\end{array}$ \\
\hline $\begin{array}{l}1971-72 \\
1972-73 \\
1973-74 \\
1974-75 \\
1975-76\end{array}$ & $\begin{array}{r}1,620,076 \\
2,613,263 \\
403,107 \\
611,960 \\
1,438,337\end{array}$ & $\begin{array}{r}567,260 \\
508,593 \\
539,295 \\
741,899 \\
1,230,417\end{array}$ & $\begin{array}{r}2,187,336 \\
3,121,856 \\
942,402 \\
1,353,859 \\
2,668,754\end{array}$ & $\begin{array}{l}25.9 \\
16.3 \\
57.2 \\
54,7 \\
46,1\end{array}$ \\
\hline $\begin{array}{l}1976-77 \\
1977-78 \\
1978-79 \\
1979-80 \\
1980-81\end{array}$ & $\begin{array}{r}6,199,158 \\
187,609 \\
390,922 \\
172,687 \\
438,909\end{array}$ & $\begin{array}{r}2,062,015 \\
761,160 \\
1,09 e, 985 \\
1,305,237 \\
1,613,861\end{array}$ & $\begin{array}{r}8,261,173 \\
948,769 \\
1,483,907 \\
1,777,924 \\
2,052,770\end{array}$ & $\begin{array}{l}25.0 \\
80.2 \\
73.7 \\
73.4 \\
78.6\end{array}$ \\
\hline $\begin{array}{l}1981-82 \\
1982-83 * \\
\text { Cumulative since } \\
\text { inception }\end{array}$ & $\begin{array}{r}573,469 \\
584,440 \\
22,424,783\end{array}$ & $\begin{array}{r}2,218,905 \\
3,395,784 \\
17,816,436\end{array}$ & $\begin{array}{r}2,792,374 \\
3,980,224 \\
40,241,219\end{array}$ & $\begin{array}{l}79.5 \\
85.3 \\
44.3\end{array}$ \\
\hline
\end{tabular}

Panel A: Examples of Archival Data - Yearly Sterilization Figures

\begin{tabular}{|c|c|c|c|c|}
\hline \multirow{2}{*}{$\begin{array}{l}\text { si. } \\
\text { No. }\end{array}$} & \multirow{3}{*}{$\begin{array}{l}\begin{array}{l}\text { State/tnion } \\
\text { Territory }\end{array} \\
2 \\
\end{array}$} & \multicolumn{3}{|c|}{$1975-76$} \\
\hline & & \multicolumn{2}{|c|}{ Vasectomy Tubectomy } & \multirow{2}{*}{$\frac{\text { Total }}{5}$} \\
\hline & & 3 & 4 & \\
\hline i. & Ancthre Pradesh & 36,873 & 128.290 & 165,163 \\
\hline 2. & Aksam & 128,403 & 19.142 & 147,545 \\
\hline 3. & Bihar & 113,191 & 52,346 & $165,53 ?$ \\
\hline 4. & Gujarat & 79,999 & 73,024 & 153,023 \\
\hline 5. & Heryuna & 35,012 & 22,930 & 57,942 \\
\hline ti. & Himachal Prarlesh & 6,806 & 10,026 & 16,832 \\
\hline 7. & Jammu \& Kashmir & 5,591 & 3,921 & 9,502 \\
\hline 8. & Karnataka & 20,997 & 99,674 & 120,671 \\
\hline 9. & Kerala & 94,270 & 62,352 & 156,622 \\
\hline 10. & Madhya Pradesh & 47,264 & 64,899 & 112,163 \\
\hline 11. & Mahurashtrs & 354,219 & 257,369 & 611,588 \\
\hline 12. & Manipur & 431 & 416 & 847 \\
\hline 13. & Meghalaya & 1,011 & 1,076 & 2,087 \\
\hline 14. & Nagaland & - & - & \\
\hline 15. & Oris8a & 68,319 & 56,721 & 125,1140 \\
\hline 16. & Punjab & 10,617 & 42,466 & $53, \cap 83$ \\
\hline 17. & Rajasthan & 53,285 & 32,972 & 86,257 \\
\hline 18. & Sikkim & NR & NR & NR \\
\hline 19. & Tamil Nadu & 178,662 & 92,029 & 270,691 \\
\hline 20. & Tripura & 3,806 & 334 & 4,140 \\
\hline 21. & L'tar Pradesh & 54,010 & 74.719 & 128,729 \\
\hline 22. & West Bengal & $112,18 \mathrm{r}$ & 94,244 & 206,424 \\
\hline 23. & A \& N Islands & re & 146 & 242 \\
\hline 24. & A runachal Pradeah & 1. & 10 & 24 \\
\hline 25. & Chandigarh & $18 \mathrm{k}$ & 975 & 1.163 \\
\hline 26. & D \& X Haveli & 202 & 39 & 241 \\
\hline 27. & Delhi & 6,671 & 15.839 & 22,510 \\
\hline 28. & 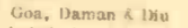 & 270 & 2,516 & 2,786 \\
\hline 2n. & Lakshadweepp & 59 & & 59 \\
\hline io. & Mizoram & 40 & 865 & 905 \\
\hline 11. & Pondichern: & $2,1+4$ & 2,544 & 4,688 \\
\hline 12. & M/o Defence & 7,905 & 6,938 & 14,843 \\
\hline 3. & M/o Railways & 15,812 & 11,595 & 27,407 \\
\hline & ALI. INDIA & $1,438,337$ & $1,230,417$ & 2668,754 \\
\hline
\end{tabular}

\section{Panel B: Examples of Archival Data - State Level Sterilization Performance}

Notes: Figure A2 presents some examples of archival data used in this paper. Panel A presents the yearly sterilization figures published in 1982-83 yearbook. Panel B presents the state-level sterilization performance in 1975-76 published in 1977-78 yearbook. 
medRxiv preprint doi: https://doi.org/10.1101/2021.01.21.21250216; this version posted August 11, 2021. The copyright holder for this preprint (which was not certified by peer review) is the author/funder, who has granted medRxiv a license to display the preprint in perpetuity.

It is made available under a CC-BY-NC-ND 4.0 International license .

Figure A3: Total Number of Sterilizations Performed in 1975-76 (Previous year)

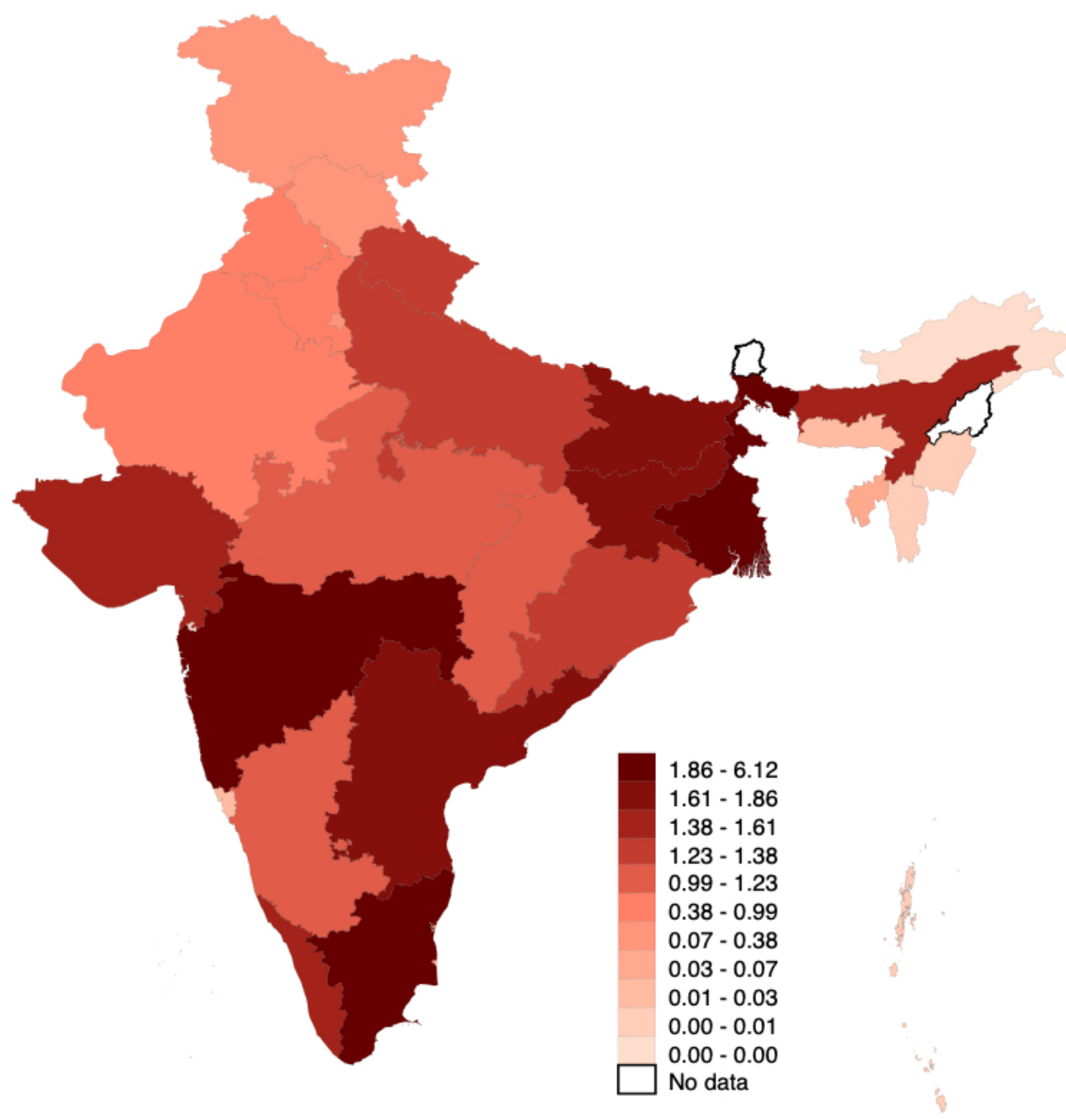

Notes: Figure A3 presents the state-level variation in the number of sterilizations performed in 1975-76 (in 100,000). Darker shades denote a greater number of sterilizations performed. 
medRxiv preprint doi: https://doi.org/10.1101/2021.01.21.21250216; this version posted August 11, 2021. The copyright holder for this preprint (which was not certified by peer review) is the author/funder, who has granted medRxiv a license to display the preprint in perpetuity.

It is made available under a CC-BY-NC-ND 4.0 International license .

Figure A4: Total Number of Sterilizations Performed in 1976-77

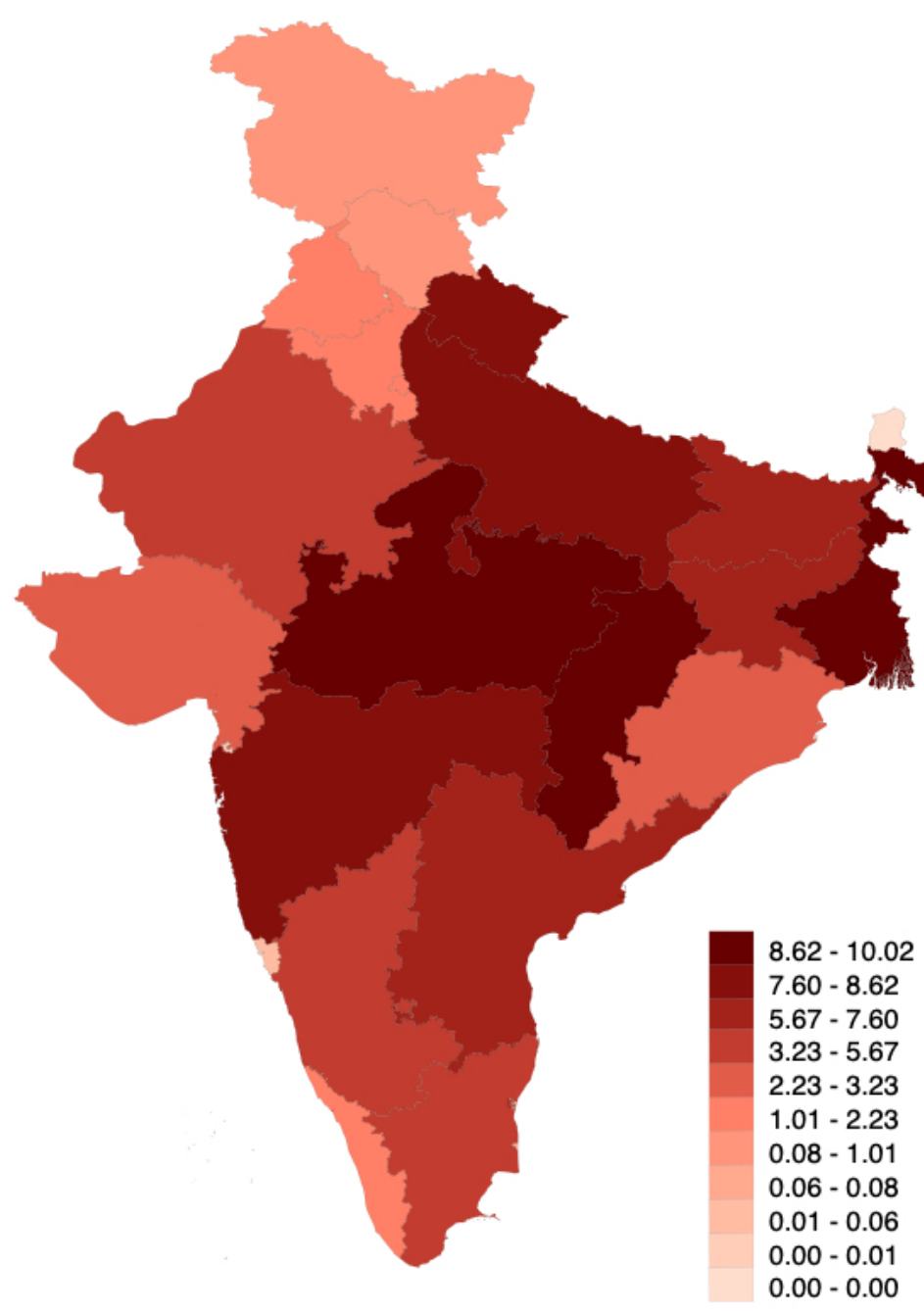

Notes: Figure A4 presents the state-level variation in the number of sterilizations performed in 1976-77. Darker shades denote a greater number of sterilizations performed. 
Figure A5: Correlation Plot for Basic Vaccination Index

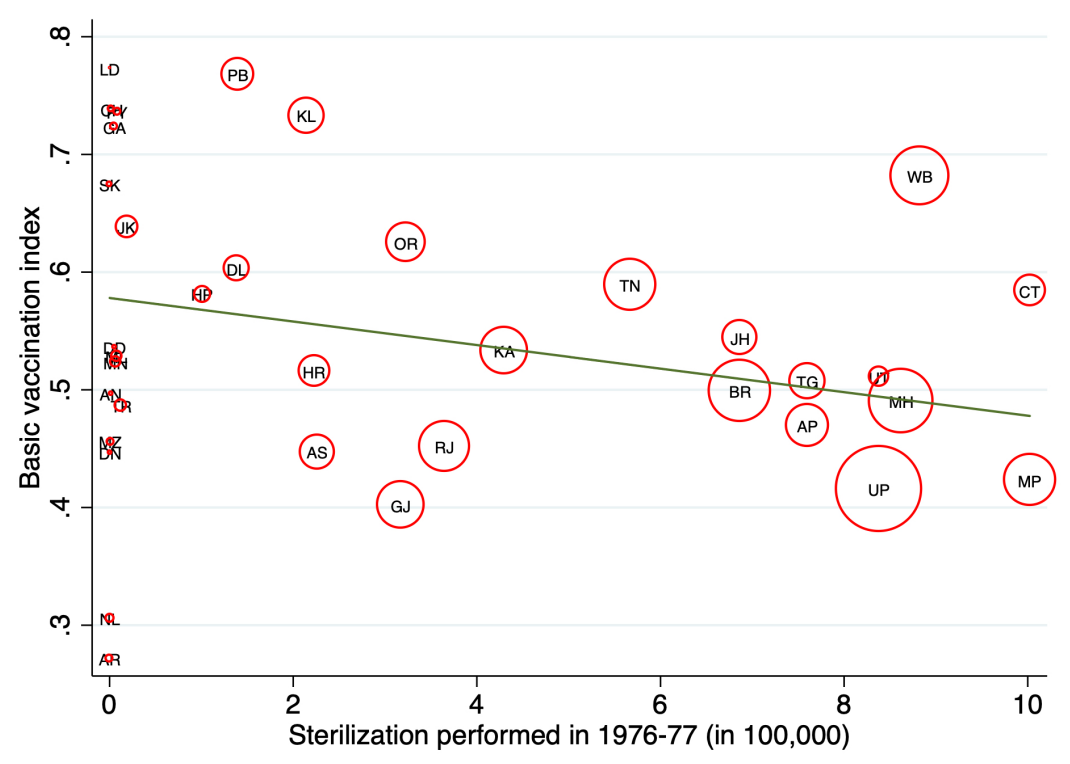

Panel A: Association between basic vaccination index and total number of sterilizations performed in $1976-77$

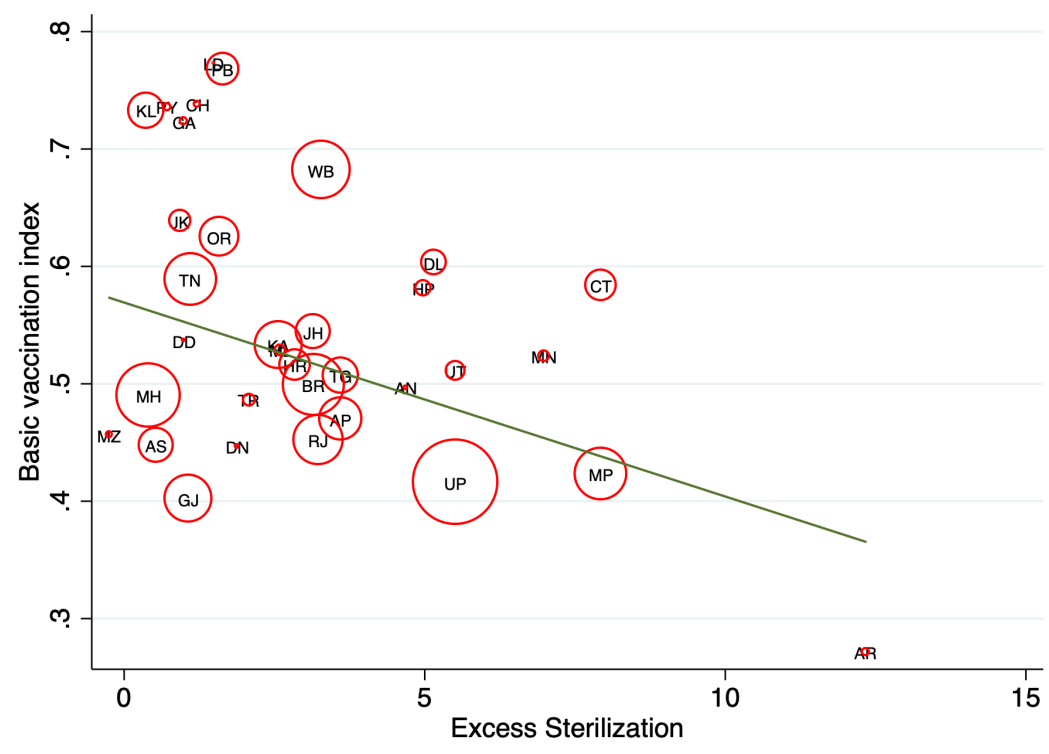

Panel B: Association between basic vaccination index and excess sterilizations performed in 197677 Normalized by 1975-76 Figures

Notes: Figure A5 presents the correlation plots of exposure to the forced sterilization policy and the basic vaccination index in 2015-16. Panel A presents the correlation between the state-level total number of sterilizations performed in 1976-77 and the basic vaccination index in 2015-16. Panel B presents the correlation between state-level excess sterilizations performed in 1976-77 and the basic vaccination index in 2015-16. The fitted lines are weighted by the population of the state and union territory. 
Figure A6: Correlation Plot for Appropriate Vaccination Index

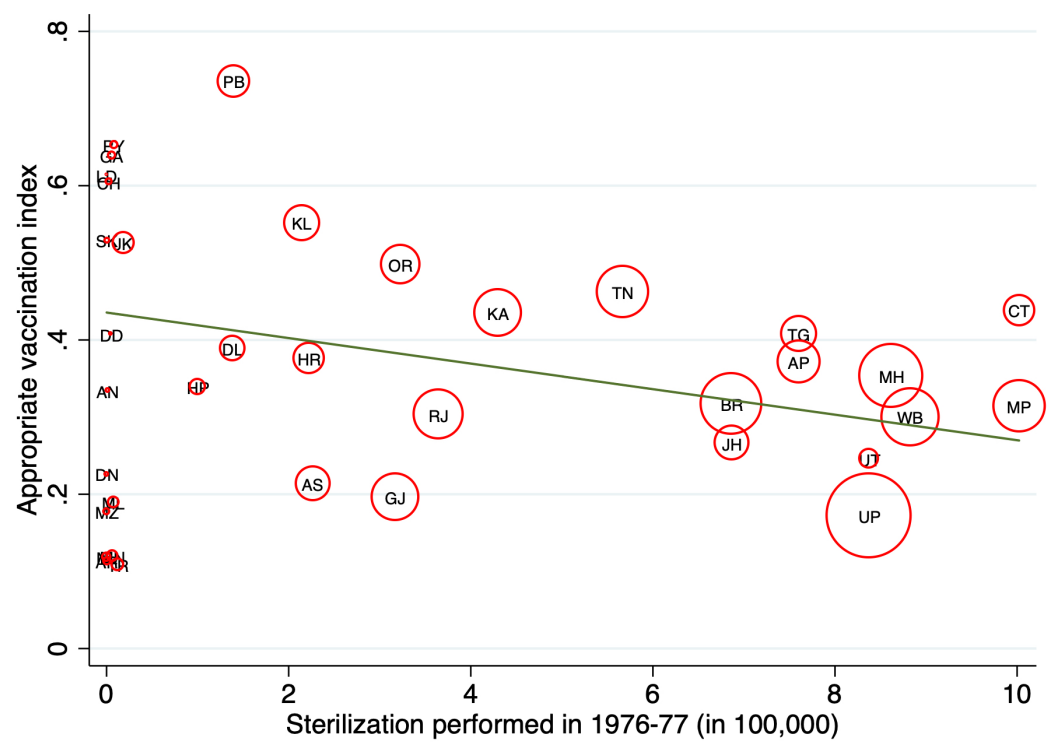

Panel A: Association between appropriate vaccination index and total number of sterilizations performed in 1976-77

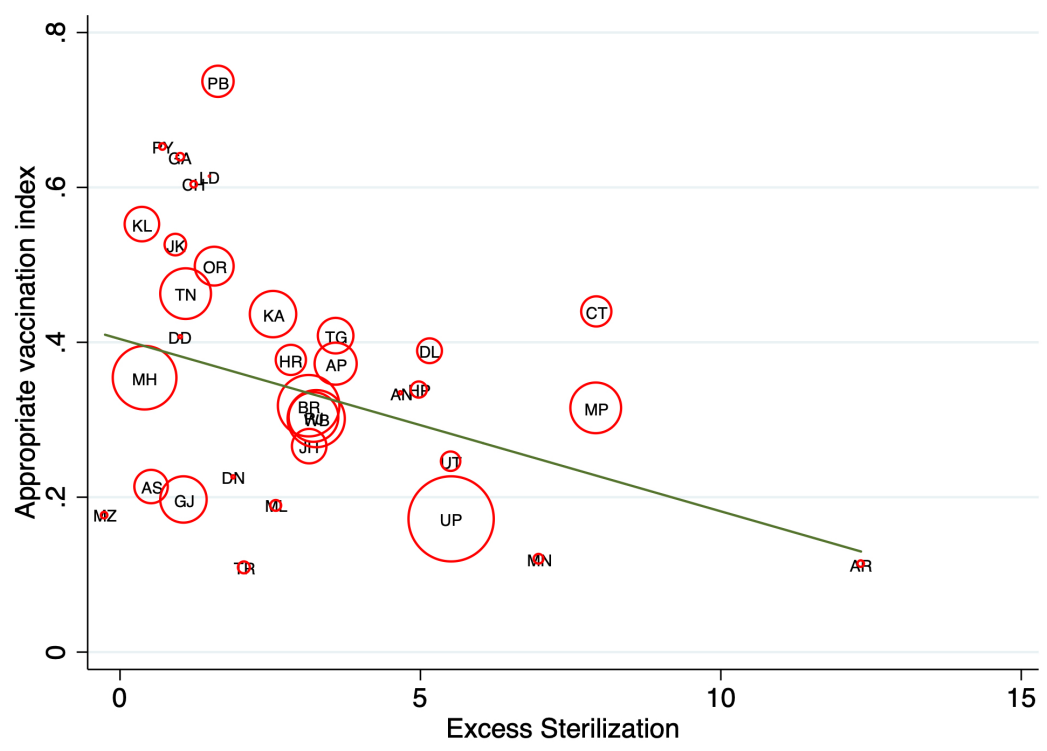

Panel B: Association between appropriate vaccination index and excess sterilizations performed in 1976-77 normalized by 1975-76 figures

Notes: Figure A6 presents correlation plots of exposure to the forced sterilization policy and the appropriate vaccination index in 2015-16. Panel A presents the correlation between the state-level total number of sterilizations performed in 1976-77 and the appropriate vaccination index in 201516. Panel B presents the correlation between state-level excess sterilizations performed in 197677 and the appropriate vaccination index in 2015-16. The fitted lines are weighted by the population of the state and union territory. 


\section{Section B: Robustness to OLS Estimates - Different Measures of Sterilization}

This section presents the robustness results to OLS estimates reported in Table 1. In Table B1, we present results considering different measures of sterilization for basic vaccination. In Table B2, we present results considering different measures of sterilization for appropriate vaccination.

\section{Table B1: Basic Vaccinations}

Dependent variable: Basic Vaccination Index

(1)

Total Sterilizations Performed in 1976-77 (in 100,000)

Total Sterilizations Performed in 1976-77 (in $\log$ )

Excess Sterilization Performed in 1976-77 (in 100,000 )

Excess Sterilization Performed in 1976-77 (in $\log$ )

Excess Sterilization

Individual Controls

Household Controls

Geographic Controls

Health Facility Controls

Observations

Mean of Dependent Variable

Mean of Explanatory variable (Sterilization measures)
(2)

(3)

(4)
(5)
$-0.00287 * * *$

$(0.000863)$

$-0.00590^{* *}$

$(0.00237)$

$-0.00177^{* *}$

$(0.000851)$

$-0.0112^{* * *}$

$(0.00225)$

$-0.00289 * * *$

(0.000924)

$\begin{array}{ccccc}\text { YES } & \text { YES } & \text { YES } & \text { YES } & \text { YES } \\ \text { YES } & \text { YES } & \text { YES } & \text { YES } & \text { YES } \\ \text { YES } & \text { YES } & \text { YES } & \text { YES } & \text { YES } \\ \text { YES } & \text { YES } & \text { YES } & \text { YES } & \text { YES } \\ & & & & \\ 234,311 & 234,311 & 229,287 & 224,679 & 229,287 \\ 0.504 & 0.504 & 0.505 & 0.505 & 0.505 \\ 6.521683 & 13.21433 & 4.709505 & 12.82417 & 3.452456\end{array}$

Notes: Data are from India's National Family and Health Survey 2015-16 (NFHS-4). The unit of observation is a child below the age of 5 . Basic vaccination index includes BCG, measles, and three doses each of DPT and polio vaccine (excluding polio vaccine given at birth). Total Sterilizations Performed in 1976-77 (in 100,000) measures the total number of sterilizations performed in a state in 1976-77 (expressed in 100,000 individuals). Total Sterilizations Performed in 1976-77 (in log) measures the natural log of the number of sterilizations performed in 1976-77. Excess Sterilization Performed in 1976-77 (in 100,000) measures the number of excess sterilizations performed in 1976-77 over and above the 1975-76 numbers (expressed in 100,000 individuals). Excess Sterilization Performed in 1976-77 (in $\log$ ) measures the natural $\log$ of the excess number of sterilizations performed in 1976-77 over and above the 1975-76 numbers. Excess Sterilization measures the number of excess sterilizations performed in 1976-77 (compared with 1975-76 numbers) normalized by the sterilization performed in 1975-76 at the state level. Individual controls are for a gender indicator variable of the child, month by year of birth fixed effects, an indicator for whether the child is twin, and birth order of the child. Household controls include age and sex of the household head, household size, number of household members below the age 5, seven religion fixed effects, four caste fixed effects, 20 education of the mother fixed effects, four household wealth index fixed effects, and an indicator for whether any household member is covered by health insurance. Geographic controls include altitude of the cluster in meters, altitude squared, state-level population density per square kilometers (in $\log$ ), and an indicator of whether the place of residence is urban. Health facility controls include hospital per 1000 population and doctors per 1000 population at the state level. Robust standard errors in parentheses clustered at the NFHS-4 cluster (PSU) level. ${ }^{* * *} \mathrm{p}<0.01,{ }^{* *} \mathrm{p}<0.05,{ }^{*} \mathrm{p}<0.1$ 


\section{Table B2: Appropriate Vaccinations}

\begin{tabular}{|c|c|c|c|c|c|}
\hline & \multicolumn{5}{|c|}{ Dependent variable: Appropriate Vaccination Index } \\
\hline & (1) & (2) & (3) & (4) & (5) \\
\hline $\begin{array}{l}\text { Total Sterilizations Performed in 1976-77 } \\
\text { (in } 100,000 \text { ) }\end{array}$ & $\begin{array}{c}-0.00837 * * * \\
(0.00106)\end{array}$ & & & & \\
\hline $\begin{array}{l}\text { Total Sterilizations Performed in 1976-77 } \\
\text { (in log) }\end{array}$ & & $\begin{array}{c}-0.00694 * * \\
(0.00314)\end{array}$ & & & \\
\hline $\begin{array}{l}\text { Excess Sterilization Performed in 1976-77 } \\
\text { (in } 100,000 \text { ) }\end{array}$ & & & $\begin{array}{c}-0.00816^{* * *} \\
(0.000978)\end{array}$ & & \\
\hline $\begin{array}{l}\text { Excess Sterilization Performed in 1976-77 } \\
\text { (in log) }\end{array}$ & & & & $\begin{array}{c}-0.0175^{* * *} \\
(0.00277)\end{array}$ & \\
\hline Excess Sterilization & & & & & $\begin{array}{c}-0.00843 * * * \\
(0.00102)\end{array}$ \\
\hline Individual Controls & YES & YES & YES & YES & YES \\
\hline Household Controls & YES & YES & YES & YES & YES \\
\hline Geographic Controls & YES & YES & YES & YES & YES \\
\hline Health Facility Controls & YES & YES & YES & YES & YES \\
\hline Observations & 231,984 & 231,984 & 226,991 & 222,393 & 226,991 \\
\hline Mean of Dependent Variable & 0.324 & 0.324 & 0.324 & 0.324 & 0.324 \\
\hline $\begin{array}{l}\text { Mean of Explanatory variable (Sterilization } \\
\text { measures) }\end{array}$ & 6.520471 & 13.21386 & 4.704912 & 12.82287 & 3.452456 \\
\hline
\end{tabular}

Notes: Data are from India's National Family and Health Survey 2015-16 (NFHS-4). The unit of observation is a child below the age of 5. Appropriate vaccination index includes BCG, measles, and three doses each of DPT, polio vaccine (excluding polio vaccine given at birth), and four doses of hepatitis B. Total Sterilizations Performed in 1976-77 (in 100,000) measures the total number of sterilizations performed in a state in 1976-77 (expressed in 100,000 individuals). Total Sterilizations Performed in 1976-77 (in $\log$ ) measures the natural $\log$ of the number of sterilizations performed in 1976-77. Excess Sterilization Performed in 1976-77 (in 100,000) measures the number of excess sterilizations performed in 1976-77 over and above the 1975-76 numbers (expressed in 100,000 individuals). Excess Sterilization Performed in 1976-77 (in log) measures the natural log of the excess number of sterilizations performed in 1976-77 over and above the 1975-76 numbers. Excess Sterilization measures the number of excess sterilizations performed in 1976-77 (compared with 1975-76 numbers) normalized by the sterilization performed in 1975-76 at the state level. Individual controls are for a gender indicator variable of the child, month by year of birth fixed effects, an indicator for whether the child is twin, and birth order of the child. Household controls include age and sex of the household head, household size, number of household members below the age 5, seven religion fixed effects, four caste fixed effects, 20 education of the mother fixed effects, four household wealth index fixed effects, and an indicator for whether any household member is covered by health insurance. Geographic controls include altitude of the cluster in meters, altitude squared, state-level population density per square kilometers (in $\log$ ), and an indicator of whether the place of residence is urban. Health facility controls include hospital per 1000 population and doctors per 1000 population at the state level. Robust standard errors in parentheses clustered at the NFHS-4 cluster (PSU) level. ${ }^{* * *} \mathrm{p}<0.01,{ }^{* *} \mathrm{p}<0.05,{ }^{*} \mathrm{p}<0.1$ 


\section{Section C: Robustness to OLS Estimates - Different Measures Vaccination}

This section presents the robustness results to OLS estimates reported in Table 2. In Table C1, we present results for basic vaccinations adding each set of controls sequentially. In Table C2, we present results for appropriate vaccinations adding each set of controls sequentially. In Table C3, we present results for all vaccinations adding each set of controls sequentially. In Table C4, we present results for the cohort of children between 12-23 months. In Table C5, we present results considering excess male sterilization (vasectomy) as an alternative measure of forced sterilization policy.

\section{Table C1: Basic Vaccinations}

\begin{tabular}{lccccc}
\hline \hline & \multicolumn{5}{c}{ Dependent variable: Basic Vaccination Index } \\
& $(1)$ & $(2)$ & $(3)$ & $(4)$ & $(5)$ \\
\hline \multirow{2}{*}{ Excess Sterilization } & $-0.0135^{* * *}$ & $-0.00978^{* * *}$ & $-0.00470^{* * *}$ & $-0.00475^{* * *}$ & $-0.00289^{* * *}$ \\
& $(0.000942)$ & $(0.000944)$ & $(0.000930)$ & $(0.000928)$ & $(0.000924)$ \\
& & & & YES & YES \\
Individual Controls & NO & YES & YES & YES & YES \\
Household Controls & NO & NO & NO & YES & YES \\
Geographic Controls & NO & NO & NO & NO & YES \\
Health Facility Controls & 238,895 & 238,895 & 229,723 & 229,287 & 229,287 \\
Observations & 0.506 & 0.506 & 0.505 & 0.505 & 0.505 \\
Mean of Dependent & & & &
\end{tabular}

Notes: Data are from India's National Family and Health Survey 2015-16 (NFHS-4). The unit of observation is a child below the age of 5. Basic vaccination index includes BCG, measles, and three doses each of DPT and polio vaccine (excluding polio vaccine given at birth). Excess Sterilization measures the number of excess sterilizations performed in 1976-77 (compared with 1975-76 numbers) normalized by the sterilization performed in 1975-76 at the state level. Individual controls are for a gender indicator variable of the child, month by year of birth fixed effects, an indicator for whether the child is twin, and birth order of the child. Household controls include age and sex of the household head, household size, number of household members below the age 5 , seven religion fixed effects, four caste fixed effects, 20 education of the mother fixed effects, four household wealth index fixed effects, and an indicator for whether any household member is covered by health insurance. Geographic controls include altitude of the cluster in meters, altitude squared, state-level population density per square kilometers (in log), and an indicator of whether the place of residence is urban. Health facility controls include hospital per 1000 population and doctors per 1000 population at the state level. Robust standard errors in parentheses clustered at the NFHS-4 cluster (PSU) level. ${ }^{* * *} \mathrm{p}<0.01,{ }^{* *} \mathrm{p}<0.05,{ }^{*} \mathrm{p}<0.1$ 
medRxiv preprint doi: https://doi.org/10.1101/2021.01.21.21250216; this version posted August 11, 2021. The copyright holder for this preprint (which was not certified by peer review) is the author/funder, who has granted medRxiv a license to display the preprint in perpetuity.

Table C2: Appropriate Vaccinations

\begin{tabular}{lccccc}
\hline \hline & \multicolumn{5}{c}{ Dependent variable: Appropriate Vaccination Index } \\
& $(1)$ & $(2)$ & $(3)$ & $(4)$ & $(5)$ \\
\hline \multirow{2}{*}{ Excess Sterilization } & $-0.0177^{* * *}$ & $-0.0143 * * *$ & $-0.00897 * * *$ & $-0.0104 * * *$ & $-0.00843^{* * *}$ \\
& $(0.00101)$ & $(0.000999)$ & $(0.000984)$ & $(0.000990)$ & $(0.00102)$ \\
& & & & & YES \\
Individual Controls & NO & YES & YES & YES & YES \\
Household Controls & NO & NO & YES & YES & YES \\
Geographic Controls & NO & NO & NO & NO & YES \\
Health Facility Controls & 236,537 & 236,537 & 227,422 & 226,991 & 226,991 \\
Observations & 0.323 & 0.323 & 0.324 & 0.324 & 0.324 \\
Mean of Dependent & & &
\end{tabular}

Notes: Data are from India's National Family and Health Survey 2015-16 (NFHS-4). The unit of observation is a child below the age of 5. Appropriate vaccination index includes BCG, measles, and three doses each of DPT, polio vaccine (excluding polio vaccine given at birth), and four doses of hepatitis B. Excess Sterilization measures the number of excess sterilizations performed in 1976-77 (compared with 1975-76 numbers) normalized by the sterilization performed in 1975-76 at the state level. Individual controls are for a gender indicator variable of the child, month by year of birth fixed effects, an indicator for whether the child is twin, and birth order of the child. Household controls include age and sex of the household head, household size, number of household members below the age 5, seven religion fixed effects, four caste fixed effects, 20 education of the mother fixed effects, four household wealth index fixed effects, and an indicator for whether any household member is covered by health insurance. Geographic controls include altitude of the cluster in meters, altitude squared, state-level population density per square kilometers (in $\log$ ), and an indicator of whether the place of residence is urban. Health facility controls include hospital per 1000 population and doctors per 1000 population at the state level. Robust standard errors in parentheses clustered at the NFHS-4 cluster (PSU) level. *** $\mathrm{p}<0.01, * * \mathrm{p}<0.05, * \mathrm{p}<0.1$ 
medRxiv preprint doi: https://doi.org/10.1101/2021.01.21.21250216; this version posted August 11, 2021. The copyright holder for this preprint (which was not certified by peer review) is the author/funder, who has granted medRxiv a license to display the preprint in perpetuity.

It is made available under a CC-BY-NC-ND 4.0 International license.

Table C3: All Vaccinations

\begin{tabular}{lccccc}
\hline \hline & \multicolumn{5}{c}{ Dependent variable: All Vaccination Index } \\
& $(1)$ & $(2)$ & $(3)$ & $(4)$ & $(5)$ \\
\hline Excess Sterilization & $-0.0178^{* * *}$ & $-0.0144^{* * *}$ & $-0.00910^{* * *}$ & $-0.0105^{* * *}$ & $-0.00860^{* * *}$ \\
& $(0.00102)$ & $(0.001000)$ & $(0.000985)$ & $(0.000992)$ & $(0.00102)$ \\
Individual Controls & NO & YES & YES & YES & YES \\
Household Controls & NO & NO & YES & YES & YES \\
Geographic Controls & NO & NO & NO & YES & YES \\
Health Facility Controls & NO & NO & NO & NO & YES \\
Observations & 236,537 & 236,537 & 227,422 & 226,991 & 226,991 \\
Mean of Dependent & 0.320 & 0.320 & 0.321 & 0.321 & 0.321 \\
Variable & & &
\end{tabular}

Notes: Data are from India's National Family and Health Survey 2015-16 (NFHS-4). The unit of observation is a child below the age of 5. All vaccination index includes BCG, measles, and three doses each of DPT, polio vaccine including polio vaccine given at birth, and four doses of hepatitis B. Excess Sterilization measures the number of excess sterilizations performed in 1976-77 (compared with 1975-76 numbers) normalized by the sterilization performed in 1975-76 at the state level. Individual controls are for a gender indicator variable of the child, month by year of birth fixed effects, an indicator for whether the child is twin, and birth order of the child. Household controls include age and sex of the household head, household size, number of household members below the age 5 , seven religion fixed effects, four caste fixed effects, 20 education of the mother fixed effects, four household wealth index fixed effects, and an indicator for whether any household member is covered by health insurance. Geographic controls include altitude of the cluster in meters, altitude squared, state-level population density per square kilometers (in log), and an indicator of whether the place of residence is urban. Health facility controls include hospital per 1000 population and doctors per 1000 population at the state level. Robust standard errors in parentheses clustered at the NFHS-4 cluster (PSU) level. ${ }^{* * *} \mathrm{p}<0.01,{ }^{* *} \mathrm{p}<0.05,{ }^{*} \mathrm{p}<0.1$ 
Table C4: Children Between 12-23 Months

\begin{tabular}{lccc}
\hline \hline Dependent variables: & $\begin{array}{c}\text { Basic } \\
\text { Vaccination } \\
\text { Index } \\
(1)\end{array}$ & $\begin{array}{c}\text { Appropriate } \\
\text { Vaccination } \\
\text { Index } \\
(2)\end{array}$ & $\begin{array}{c}\text { All Vaccination } \\
\text { Index }\end{array}$ \\
\hline Excess Sterilization & 0.000990 & $-0.00341^{*}$ & $(3)$ \\
& $(0.00168)$ & $(0.00181)$ & $-0.00373^{* *}$ \\
& & & \\
Individual Controls & YES & YES & YES \\
Household Controls & YES & YES & YES \\
Geographic Controls & YES & YES & YES \\
Health Facility Controls & & & YES \\
Observations & 45,639 & 45,252 & 45,252 \\
Mean of Dependent Variable & 0.624 & 0.439 & 0.435 \\
Mean of Excess Sterilization & 3.437 & 3.432 & 3.432 \\
\hline
\end{tabular}

Notes: Data are from India's National Family and Health Survey 2015-16 (NFHS4). The unit of observation is a child between 12-23 months. Basic vaccination index includes BCG, measles, and three doses each of DPT and polio vaccine (excluding polio vaccine given at birth). Appropriate vaccination index includes all basic vaccinations plus four doses of hepatitis B. All vaccination index includes all appropriate vaccination plus polio vaccine given at birth. Excess Sterilization measures the number of excess sterilizations performed in 1976-77 (compared with 1975-76 numbers) normalized by the sterilization performed in 1975-76 at the state level. Individual controls are for a gender indicator variable of the child, month by year of birth fixed effects, an indicator for whether the child is twin, and birth order of the child. Household controls include age and sex of the household head, household size, number of household members below the age 5, seven religion fixed effects, four caste fixed effects, 20 education of the mother fixed effects, four household wealth index fixed effects, and an indicator for whether any household member is covered by health insurance. Geographic controls include altitude of the cluster in meters, altitude squared, state-level population density per square kilometers (in $\log$ ), and an indicator of whether the place of residence is urban. Health facility controls include hospital per 1000 population and doctors per 1000 population at the state level. Robust standard errors in parentheses clustered at the NFHS-4 cluster (PSU) level. *** $\mathrm{p}<0.01,{ }^{* *} \mathrm{p}<0.05,{ }^{*} \mathrm{p}<0.1$ 
medRxiv preprint doi: https://doi.org/10.1101/2021.01.21.21250216; this version posted August 11, 2021. The copyright holder for this preprint (which was not certified by peer review) is the author/funder, who has granted medRxiv a license to display the preprint in perpetuity.

It is made available under a CC-BY-NC-ND 4.0 International license .

Table C5: Alternative Measures of Force Sterilization Policy - Male Sterilization

\begin{tabular}{lccc}
\hline \hline & $\begin{array}{c}\text { Basic } \\
\text { Vaccination } \\
\text { Index } \\
(1)\end{array}$ & $\begin{array}{c}\text { Appropriate } \\
\text { Vaccination } \\
\text { Index } \\
(2)\end{array}$ & $\begin{array}{c}\text { All Vaccination } \\
\text { Index }\end{array}$ \\
\hline & & & $(3)$ \\
Excess Male Sterilization & $-0.00291^{* * *}$ & $-0.00275^{* * *}$ & $-0.00279^{* * *}$ \\
(Vasectomy) & $(0.000385)$ & $(0.000430)$ & $(0.000431)$ \\
& & & \\
Individual Controls & YES & YES & YES \\
Household Controls & YES & YES & YES \\
Geographic Controls & YES & YES & YES \\
Health Facility Controls & & & YES \\
& 229,287 & 226,991 & 226,991 \\
Observations & 0.505 & 0.324 & 0.321 \\
Mean of Dependent Variable & 7.29167 & 7.284252 & 7.284252 \\
Mean of Excess Male Sterilization & (Vasectomy) & &
\end{tabular}

Notes: Data are from India's National Family and Health Survey 2015-16 (NFHS-4). The unit of observation is a child below the age of 5. Basic vaccination index includes $\mathrm{BCG}$, measles, and three doses each of DPT and polio vaccine (excluding polio vaccine given at birth). Appropriate vaccination index includes all basic vaccinations plus four doses of hepatitis B. All vaccination index includes all appropriate vaccination plus polio vaccine given at birth. Excess Male Sterilization (Vasectomy) measures the number of excess vasectomies performed in 1976-77 (compared with 1975-76 numbers) normalized by the vasectomy performed in 1975-76 at the state level. Individual controls are for a gender indicator variable of the child, month by year of birth fixed effects, an indicator for whether the child is twin, and birth order of the child. Household controls include age and sex of the household head, household size, number of household members below the age 5, seven religion fixed effects, four caste fixed effects, 20 education of the mother fixed effects, four household wealth index fixed effects, and an indicator for whether any household member is covered by health insurance. Geographic controls include altitude of the cluster in meters, altitude squared, state-level population density per square kilometers (in log), and an indicator of whether the place of residence is urban. Health facility controls include hospital per 1000 population and doctors per 1000 population at the state level. Robust standard errors in parentheses clustered at the NFHS-4 cluster (PSU) level. ${ }^{* * *} \mathrm{p}<0.01,{ }^{* *} \mathrm{p}<0.05$, * $\mathrm{p}<0.1$ 


\section{Section D: Robustness to IV Estimates}

This section presents the robustness results to IV estimates reported in Table 3 . In Table D1, we present results for basic vaccinations adding each set of controls sequentially. In Table D2, we present results for appropriate vaccinations adding each set of controls sequentially. In Table D3, we present results for all vaccinations adding each set of controls sequentially. In Table D4, we present results for the cohort of children between 12-23 months. In Table D5, we present results considering excess male sterilization (vasectomy) as an alternative measure of forced sterilization policy.

\section{Table D1: Basic Vaccinations}

\begin{tabular}{lccccc}
\hline \hline & \multicolumn{5}{c}{ Dependent variable: Basic Vaccination Index } \\
& $(1)$ & $(2)$ & $(3)$ & $(4)$ & $(5)$ \\
\hline Excess Sterilization & -0.0374 & -0.0194 & -0.0121 & -0.0134 & -0.00996 \\
& $(0.00186)$ & $(0.00184)$ & $(0.00187)$ & $(0.00177)$ & $(0.00189)$ \\
& {$[0.00504]$} & {$[0.00530]$} & {$[0.00474]$} & {$[0.00451]$} & {$[0.00449]$} \\
& $\{0.0140\}$ & $\{0.0136\}$ & $\{0.0116\}$ & $\{0.0116\}$ & $\{0.00965\}$ \\
& $((0.00637))$ & $((0.00690))$ & $((0.00562))$ & $((0.00525))$ & $((0.00529))$ \\
Individual Controls & NO & YES & YES & YES & YES \\
Household Controls & NO & NO & YES & YES & YES \\
Geographic Controls & NO & NO & NO & YES & YES \\
Health Facility Controls & NO & NO & NO & NO & YES \\
Observations & 238,895 & 238,895 & 229,723 & 229,287 & 229,287 \\
Mean of Dependent & 0.506 & 0.506 & 0.505 & 0.505 & 0.505 \\
Variable &
\end{tabular}

Notes: Data are from India's National Family and Health Survey 2015-16 (NFHS-4). The unit of observation is a child below the age of 5. Basic vaccination index includes BCG, measles, and three doses each of DPT and polio vaccine (excluding polio vaccine given at birth). Excess Sterilization measures the number of excess sterilizations performed in 1976-77 (compared with 1975-76 numbers) normalized by the sterilization performed in 1975-76 at the state level. Individual controls are for a gender indicator variable of the child, month by year of birth fixed effects, an indicator for whether the child is twin, and birth order of the child. Household controls include age and sex of the household head, household size, number of household members below the age 5, seven religion fixed effects, four caste fixed effects, 20 education of the mother fixed effects, four household wealth index fixed effects, and an indicator for whether any household member is covered by health insurance. Geographic controls include altitude of the cluster in meters, altitude squared, state-level population density per square kilometers (in log), and an indicator of whether the place of residence is urban. Health facility controls include hospital per 1000 population and doctors per 1000 population at the state level. Below each coefficient four standard errors are reported. The first, reported in parentheses, is standard errors adjusted for clustering at the NFHS-4 cluster (PSU) level. The second, reported in square brackets, is standard errors adjusted for clustering at the current district level. The third, reported in curly brackets, is standard errors adjusted for clustering at the current state level. The fourth, reported in double parenthesis, is standard errors adjusted for spatial correction proposed by Conley (1999). 


\section{Table D2: Appropriate Vaccinations}

\begin{tabular}{lccccc}
\hline \hline & \multicolumn{5}{c}{ Dependent variable: Appropriate Vaccination Index } \\
& $(1)$ & $(2)$ & $(3)$ & $(4)$ & $(5)$ \\
\hline Excess Sterilization & -0.0398 & -0.0276 & -0.0242 & -0.0254 & -0.0232 \\
& $(0.00214)$ & $(0.00212)$ & $(0.00214)$ & $(0.00212)$ & $(0.00229)$ \\
& {$[0.00523]$} & {$[0.00532]$} & {$[0.00460]$} & {$[0.00472]$} & {$[0.00518]$} \\
& $\{0.0171\}$ & $\{0.0174\}$ & $\{0.0124\}$ & $\{0.0121\}$ & $\{0.0111\}$ \\
& $((0.0065))$ & $((0.0068))$ & $((0.0050))$ & $((0.0051))$ & $((0.0055))$ \\
Individual Controls & NO & YES & YES & YES & YES \\
Household Controls & NO & NO & YES & YES & YES \\
Geographic Controls & NO & NO & NO & YES & YES \\
Health Facility Controls & NO & NO & NO & NO & YES \\
Observations & 236,537 & 236,537 & 227,422 & 226,991 & 226,991 \\
Mean of Dependent & 0.323 & 0.323 & 0.324 & 0.324 & 0.324 \\
Variable & &
\end{tabular}

Notes: Data are from India's National Family and Health Survey 2015-16 (NFHS-4). The unit of observation is a child below the age of 5. Appropriate vaccination index includes BCG, measles, and three doses each of DPT, polio vaccine (excluding polio vaccine given at birth), and four doses of hepatitis B. Excess Sterilization measures the number of excess sterilizations performed in 1976-77 (compared with 1975-76 numbers) normalized by the sterilization performed in 1975-76 at the state level. Individual controls are for a gender indicator variable of the child, month by year of birth fixed effects, an indicator for whether the child is twin, and birth order of the child. Household controls include age and sex of the household head, household size, number of household members below the age 5, seven religion fixed effects, four caste fixed effects, 20 education of the mother fixed effects, four household wealth index fixed effects, and an indicator for whether any household member is covered by health insurance. Geographic controls include altitude of the cluster in meters, altitude squared, state-level population density per square kilometers (in $\log$ ), and an indicator of whether the place of residence is urban. Health facility controls include hospital per 1000 population and doctors per 1000 population at the state level. Below each coefficient four standard errors are reported. The first, reported in parentheses, is standard errors adjusted for clustering at the NFHS-4 cluster (PSU) level. The second, reported in square brackets, is standard errors adjusted for clustering at the current district level. The third, reported in curly brackets, is standard errors adjusted for clustering at the current state level. The fourth, reported in double parenthesis, is standard errors adjusted for spatial correction proposed by Conley (1999). 
Table D3: All Vaccinations

\begin{tabular}{lccccc}
\hline \hline & \multicolumn{5}{c}{ Dependent variable: All Vaccination Index } \\
& $(1)$ & $(2)$ & $(3)$ & $(4)$ & $(5)$ \\
\hline Excess Sterilization & -0.0399 & -0.0278 & -0.0245 & -0.0258 & -0.0236 \\
& $(0.00214)$ & $(0.00213)$ & $(0.00215)$ & $(0.00213)$ & $(0.00231)$ \\
& {$[0.00525]$} & {$[0.00534]$} & {$[0.00463]$} & {$[0.00477]$} & {$[0.00525]$} \\
& $\{0.0172\}$ & $\{0.0175\}$ & $\{0.0124\}$ & $\{0.0121\}$ & $\{0.0112\}$ \\
& $((0.0065))$ & $((0.0068))$ & $((0.0050))$ & $((0.0051))$ & $((0.00554))$ \\
Individual Controls & NO & YES & YES & YES & YES \\
Household Controls & NO & NO & YES & YES & YES \\
Geographic Controls & NO & NO & NO & YES & YES \\
Health Facility Controls & NO & NO & NO & NO & YES \\
Observations & 236,537 & 236,537 & 227,422 & 226,991 & 226,991 \\
Mean of Dependent & 0.320 & 0.320 & 0.321 & 0.321 & 0.321 \\
Variable & &
\end{tabular}

Notes: Data are from India's National Family and Health Survey 2015-16 (NFHS-4). The unit of observation is a child below the age of 5. All vaccination index includes BCG, measles, and three doses each of DPT, polio vaccine including polio vaccine given at birth, and four doses of hepatitis B. Excess Sterilization measures the number of excess sterilizations performed in 1976-77 (compared with 1975-76 numbers) normalized by the sterilization performed in 1975-76 at the state level. Individual controls are for a gender indicator variable of the child, month by year of birth fixed effects, an indicator for whether the child is twin, and birth order of the child. Household controls include age and sex of the household head, household size, number of household members below the age 5, seven religion fixed effects, four caste fixed effects, 20 education of the mother fixed effects, four household wealth index fixed effects, and an indicator for whether any household member is covered by health insurance. Geographic controls include altitude of the cluster in meters, altitude squared, state-level population density per square kilometers (in $\log$ ), and an indicator of whether the place of residence is urban. Health facility controls include hospital per 1000 population and doctors per 1000 population at the state level. Below each coefficient four standard errors are reported. The first, reported in parentheses, is standard errors adjusted for clustering at the NFHS-4 cluster (PSU) level. The second, reported in square brackets, is standard errors adjusted for clustering at the current district level. The third, reported in curly brackets, is standard errors adjusted for clustering at the current state level. The fourth, reported in double parenthesis, is standard errors adjusted for spatial correction proposed by Conley (1999). 
Table D4: Children Between 12-23 Months

\begin{tabular}{|c|c|c|c|}
\hline & \multicolumn{3}{|c|}{ Panel A: First Stage Estimates } \\
\hline & \multicolumn{3}{|c|}{$\begin{array}{l}\text { Dependent variable: Excess Sterilization } \\
\text { (1) }\end{array}$} \\
\hline \multirow[t]{6}{*}{ Distance from New Delhi (in 100km) } & -0.268 & -0.268 & -0.268 \\
\hline & $(0.00308)$ & $(0.00308)$ & $(0.00308)$ \\
\hline & {$[0.0137]$} & {$[0.0137]$} & {$[0.0137]$} \\
\hline & $\{0.0662\}$ & $\{0.0662\}$ & $\{0.0662\}$ \\
\hline & $((0.0178))$ & $((0.0178))$ & $((0.0178))$ \\
\hline & \multicolumn{3}{|c|}{ Panel B: Second Stage Estimates } \\
\hline Dependent variables: & $\begin{array}{c}\text { Basic } \\
\text { Vaccination } \\
\text { Index } \\
(1) \\
\end{array}$ & $\begin{array}{c}\text { Appropriate } \\
\text { Vaccination } \\
\text { Index } \\
(2) \\
\end{array}$ & $\begin{array}{c}\text { All Vaccination } \\
\text { Index } \\
(3)\end{array}$ \\
\hline Excess Sterilization & $\begin{array}{c}-0.0213 \\
(0.00301) \\
{[0.00498]} \\
\{0.0118\} \\
((0.00605))\end{array}$ & $\begin{array}{c}-0.0267 \\
(0.00333) \\
{[0.00589]} \\
\{0.0146\} \\
((0.00637))\end{array}$ & $\begin{array}{c}-0.0272 \\
(0.00333) \\
{[0.00591]} \\
\{0.0147\} \\
((0.00637))\end{array}$ \\
\hline Individual Controls & YES & YES & YES \\
\hline Household Controls & YES & YES & YES \\
\hline Geographic Controls & YES & YES & YES \\
\hline Health Facility Controls & YES & YES & YES \\
\hline Observations & 45,639 & 45,252 & 45,252 \\
\hline F Stat of Excluded Instrument & 16.35 & 16.36 & 16.36 \\
\hline Mean of Dependent Variable & 0.624 & 0.439 & 0.435 \\
\hline Mean of Excess Sterilization & 3.437 & 3.432 & 3.432 \\
\hline
\end{tabular}

Notes: Data are from India's National Family and Health Survey 2015-16 (NFHS-4). The unit of observation is a child between 12-23 months. Basic vaccination index includes BCG, measles, and three doses each of DPT and polio vaccine (excluding polio vaccine given at birth). Appropriate vaccination index includes all basic vaccinations plus four doses of hepatitis B. All vaccination index includes all appropriate vaccination plus polio vaccine given at birth. Excess Sterilization measures the number of excess sterilizations performed in 1976-77 (compared with 1975-76 numbers) normalized by the sterilization performed in 1975-76 at the state level. Individual controls are for a gender indicator variable of the child, month by year of birth fixed effects, an indicator for whether the child is twin, and birth order of the child. Household controls include age and sex of the household head, household size, number of household members below the age 5 , seven religion fixed effects, four caste fixed effects, 20 education of the mother fixed effects, four household wealth index fixed effects, and an indicator for whether any household member is covered by health insurance. Geographic controls include altitude of the cluster in meters, altitude squared, state-level population density per square kilometers (in $\log$ ), and an indicator of whether the place of residence is urban. Health facility controls include hospital per 1000 population and doctors per 1000 population at the state level. Below each coefficient four standard errors are reported. The first, reported in parentheses, is standard errors adjusted for clustering at the NFHS-4 cluster (PSU) level. The second, reported in square brackets, is standard errors adjusted for clustering at the current district level. The third, reported in curly brackets, is standard errors adjusted for clustering at the current state level. The fourth, reported in double parenthesis, is standard errors adjusted for spatial correction proposed by Conley (1999). The reported F Statistics of Excluded Instrument is based on adjusting standard errors for clustering at the state-level. 


\section{Table D5: Alternative Measures of Force Sterilization Policy - Male Sterilization}

\begin{tabular}{|c|c|c|c|}
\hline & \multicolumn{3}{|c|}{ Panel A: First Stage Estimates } \\
\hline & \multicolumn{3}{|c|}{$\begin{array}{c}\text { Dependent variable: Male Sterilization } \\
\text { (Vasectomy) }\end{array}$} \\
\hline & $(1)$ & $(2)$ & (3) \\
\hline \multirow[t]{10}{*}{ Distance from New Delhi (in 100km) } & -0.478 & -0.478 & -0.478 \\
\hline & $(0.00769)$ & $(0.00769)$ & $(0.00769)$ \\
\hline & {$[0.0394]$} & {$[0.0394]$} & {$[0.0394]$} \\
\hline & $\{0.191\}$ & $\{0.191\}$ & $\{0.191\}$ \\
\hline & $((0.0458))$ & $((0.0458))$ & $((0.0458))$ \\
\hline & \multicolumn{3}{|c|}{ Panel B: Second Stage Estimates } \\
\hline & Basic & Appropriate & All \\
\hline & Vaccination & Vaccination & Vaccination \\
\hline & Index & Index & Index \\
\hline & $(1)$ & $(2)$ & $(3)$ \\
\hline \multirow[t]{5}{*}{ Excess Male Sterilization (Vasectomy) } & -0.00513 & -0.0119 & -0.0121 \\
\hline & $(0.000978)$ & $(0.00121)$ & $(0.00122)$ \\
\hline & {$[0.00233]$} & {$[0.00274]$} & {$[0.00277]$} \\
\hline & $\{0.00514\}$ & $\{0.00614\}$ & $\{0.00618\}$ \\
\hline & $((0.00269))$ & $((0.00282))$ & $((0.00285))$ \\
\hline Individual Controls & YES & YES & YES \\
\hline Household Controls & YES & YES & YES \\
\hline Geographic Controls & YES & YES & YES \\
\hline Health Facility Controls & YES & YES & YES \\
\hline Observations & 229,287 & 226,991 & 226,991 \\
\hline F Stat of Excluded Instrument & 6.25 & 6.25 & 6.25 \\
\hline Mean of Dependent Variable & 0.505 & 0.324 & 0.321 \\
\hline $\begin{array}{l}\text { Mean of Excess Male Sterilization } \\
\text { (Vasectomy) }\end{array}$ & 7.292 & 7.284 & 7.284 \\
\hline
\end{tabular}

Notes: Data are from India's National Family and Health Survey 2015-16 (NFHS-4). The unit of observation is a child below the age of 5 . Basic vaccination index includes BCG, measles, and three doses each of DPT and polio vaccine (excluding polio vaccine given at birth). Appropriate vaccination index includes all basic vaccinations plus four doses of hepatitis B. All vaccination index includes all appropriate vaccination plus polio vaccine given at birth. Excess Male Sterilization (Vasectomy) measures the number of excess vasectomies performed in 1976-77 (compared with 1975-76 numbers) normalized by the vasectomy performed in 1975-76 at the state level. Individual controls are for a gender indicator variable of the child, month by year of birth fixed effects, an indicator for whether the child is twin, and birth order of the child. Household controls include age and sex of the household head, household size, number of household members below the age 5 , seven religion fixed effects, four caste fixed effects, 20 education of the mother fixed effects, four household wealth index fixed effects, and an indicator for whether any household member is covered by health insurance. Geographic controls include altitude of the cluster in meters, altitude squared, state-level population density per square kilometers (in log), and an indicator of whether the place of residence is urban. Health facility controls include hospital per 1000 population and doctors per 1000 population at the state level. Below each coefficient four standard errors are reported. The first, reported in parentheses, is standard errors adjusted for clustering at the NFHS-4 cluster (PSU) level. The second, reported in square brackets, is standard errors adjusted for clustering at the current district level. The third, reported in curly brackets, is standard errors adjusted for clustering at the current state level. The fourth, reported in double parenthesis, is standard errors adjusted for spatial correction proposed by Conley (1999). The reported F Statistics of Excluded Instrument is based on adjusting standard errors for clustering at the state-level. 


\section{Section E: Heterogenous Effects and Robustness}

This section presents the heterogenous effects and robustness to estimates reported in Figure 5. In Table E1, we present the results of Figure 5 in Table format. In Table E2, we present results for the cohort of children between 12-23 months. In Table E3, we present results considering excess male sterilization (vasectomy) as an alternative measure of forced sterilization policy.

Table E1: Heterogenous Effects (Tabular format)

\begin{tabular}{|c|c|c|c|c|c|c|c|c|c|c|c|c|c|}
\hline Dependent variables: & $\begin{array}{l}\text { Hepatitis } 0 \\
\text { (1) }\end{array}$ & $\begin{array}{l}\text { Hepatitis } 1 \\
\text { (2) }\end{array}$ & $\begin{array}{l}\text { Hepatitis } 2 \\
\text { (3) }\end{array}$ & $\begin{array}{c}\text { Hepatitis } 3 \\
\text { (4) }\end{array}$ & $\begin{array}{c}\text { BCG } \\
(5)\end{array}$ & $\begin{array}{l}\text { DPT } 1 \\
(6)\end{array}$ & $\begin{array}{c}\text { DPT } 2 \\
(7)\end{array}$ & $\begin{array}{c}\text { DPT } 3 \\
(8)\end{array}$ & $\begin{array}{c}\text { Polio } 0 \\
(9)\end{array}$ & $\begin{array}{c}\text { Polio } 1 \\
(10)\end{array}$ & $\begin{array}{c}\text { Polio } 2 \\
(11)\end{array}$ & $\begin{array}{l}\text { Polio } 3 \\
(12)\end{array}$ & $\begin{array}{c}\text { Measles } \\
\text { (13) }\end{array}$ \\
\hline Excess Sterilization & $\begin{array}{c}-0.0264^{* *} \\
(0.0126)\end{array}$ & $\begin{array}{l}-0.00993 \\
(0.00926)\end{array}$ & $\begin{array}{l}-0.0109 \\
(0.0105)\end{array}$ & $\begin{array}{l}-0.0230^{*} \\
(0.0119)\end{array}$ & $\begin{array}{l}-0.00420 \\
(0.00405)\end{array}$ & $\begin{array}{l}-0.00379 \\
(0.00521)\end{array}$ & $\begin{array}{l}-0.00711 \\
(0.00671)\end{array}$ & $\begin{array}{c}-0.0141 \\
(0.00882)\end{array}$ & $\begin{array}{c}-0.0303 * * * \\
(0.0103)\end{array}$ & $\begin{array}{l}-0.00479 \\
(0.00464)\end{array}$ & $\begin{array}{l}-0.0101 \\
(0.00696)\end{array}$ & $\begin{array}{l}-0.00843 \\
(0.00825)\end{array}$ & $\begin{array}{c}0.00221 \\
(0.00776)\end{array}$ \\
\hline Individual Controls & YES & YES & YES & YES & YES & YES & YES & YES & YES & YES & YES & YES & YES \\
\hline Household Controls & YES & YES & YES & YES & YES & YES & YES & YES & YES & YES & YES & YES & YES \\
\hline Geographic Controls & YES & YES & YES & YES & YES & YES & YES & YES & YES & YES & YES & YES & YES \\
\hline $\begin{array}{l}\text { Health Facility } \\
\text { Controls }\end{array}$ & YES & YES & YES & YES & YES & YES & YES & YES & YES & YES & YES & YES & YES \\
\hline Observations & 228,537 & 228,537 & 228,537 & 228,537 & 231,946 & 231,078 & 231,078 & 231,078 & 231,929 & 231,929 & 231,929 & 231,929 & 230,575 \\
\hline $\begin{array}{l}\text { Mean of Dependent } \\
\text { Variable }\end{array}$ & 0.622 & 0.761 & 0.697 & 0.526 & 0.897 & 0.851 & 0.795 & 0.713 & 0.760 & 0.858 & 0.795 & 0.642 & 0.704 \\
\hline $\begin{array}{l}\text { Notes: Data are from } \\
\text { sterilizations perform } \\
\text { variable of the child, } \\
\text { head, household size, } \\
\text { index fixed effects, } \\
\text { level population dens }\end{array}$ & indicator & or whether & househol & member is & $\mathrm{S}-4) . \mathrm{Tl}$ & thinces, & Geogr & Contio & clude alt & of the $c$ & tal per 1 & populat & $\begin{array}{l}\text { er of excess } \\
\text { er indicator } \\
\text { householc } \\
\text { hold wealth } \\
\text { lared, state- } \\
\text { and doctors }\end{array}$ \\
\hline
\end{tabular}


Table E2: Children Between 12-23 Months

\begin{tabular}{|c|c|c|c|c|c|c|c|c|c|c|c|c|c|}
\hline Dependent variables: & $\begin{array}{c}\text { Hepatitis } 0 \\
\text { (1) }\end{array}$ & $\begin{array}{c}\text { Hepatitis } 1 \\
\text { (2) }\end{array}$ & $\begin{array}{c}\text { Hepatitis } 2 \\
\text { (3) }\end{array}$ & $\begin{array}{c}\text { Hepatitis } 3 \\
\text { (4) }\end{array}$ & $\begin{array}{c}\text { BCG } \\
(5)\end{array}$ & $\begin{array}{c}\text { DPT } 1 \\
(6) \\
\end{array}$ & $\begin{array}{l}\text { DPT } 2 \\
(7)\end{array}$ & $\begin{array}{c}\text { DPT } 3 \\
(8) \\
\end{array}$ & $\begin{array}{c}\text { Polio } 0 \\
(9)\end{array}$ & $\begin{array}{c}\text { Polio } 1 \\
(10)\end{array}$ & $\begin{array}{c}\text { Polio } 2 \\
(11) \\
\end{array}$ & $\begin{array}{c}\text { Polio } 3 \\
(12) \\
\end{array}$ & $\begin{array}{c}\text { Measles } \\
(13)\end{array}$ \\
\hline Excess Sterilization & $\begin{array}{c}-0.0230^{*} \\
(0.0136)\end{array}$ & $\begin{array}{c}-0.00765 \\
(0.0109)\end{array}$ & $\begin{array}{c}-0.0102 \\
(0.0126)\end{array}$ & $\begin{array}{l}-0.0209 \\
(0.0140)\end{array}$ & $\begin{array}{l}-0.00281 \\
(0.00359)\end{array}$ & $\begin{array}{c}-0.00292 \\
(0.00491)\end{array}$ & $\begin{array}{c}-0.00704 \\
(0.00682)\end{array}$ & $\begin{array}{c}-0.0152 \\
(0.00941)\end{array}$ & $\begin{array}{c}-0.0249^{* *} \\
(0.0106)\end{array}$ & $\begin{array}{c}-0.00735^{*} \\
(0.00441)\end{array}$ & $\begin{array}{c}-0.0135^{* *} \\
(0.00621)\end{array}$ & $\begin{array}{l}-0.0160^{*} \\
(0.00845)\end{array}$ & $\begin{array}{c}-0.00913 \\
(0.00756)\end{array}$ \\
\hline Individual Controls & YES & YES & YES & YES & YES & YES & YES & YES & YES & YES & YES & YES & YES \\
\hline Household Controls & YES & YES & YES & YES & YES & YES & YES & YES & YES & YES & YES & YES & YES \\
\hline Geographic Controls & YES & YES & YES & YES & YES & YES & YES & YES & YES & YES & YES & YES & YES \\
\hline Health Facility Controls & YES & YES & YES & YES & YES & YES & YES & YES & YES & YES & YES & YES & YES \\
\hline $\begin{array}{l}\text { Observations } \\
\text { Mean of Dependent Variable }\end{array}$ & $\begin{array}{c}45,533 \\
0.668\end{array}$ & $\begin{array}{c}45,533 \\
0.829\end{array}$ & $\begin{array}{c}45,533 \\
0.779\end{array}$ & $\begin{array}{c}45,533 \\
0.639\end{array}$ & $\begin{array}{c}46,094 \\
0.920\end{array}$ & $\begin{array}{c}45,951 \\
0.896\end{array}$ & $\begin{array}{c}45,951 \\
0.860\end{array}$ & $\begin{array}{c}45,951 \\
0.790\end{array}$ & $\begin{array}{c}46,089 \\
0.795\end{array}$ & $\begin{array}{c}46,089 \\
0.905\end{array}$ & $\begin{array}{c}46,089 \\
0.860\end{array}$ & $\begin{array}{c}46,089 \\
0.734\end{array}$ & $\begin{array}{c}45,850 \\
0.815\end{array}$ \\
\hline $\begin{array}{l}\text { Notes: Data are from India's } \\
\text { sterilizations performed in } 19 \\
\text { the child, month by year of b } \\
\text { number of household member } \\
\text { for whether any household me } \\
\text { log), and an indicator of whet } \\
\text { in parentheses clustered at the }\end{array}$ & $\begin{array}{l}\text { tional Famil } \\
-77 \text { (compar } \\
\text { fixed effec } \\
\text { elow the age } \\
\text { ber is covere } \\
\text { the place o } \\
\text { ate level. ** }\end{array}$ & $\begin{array}{l}\text { and Health } \\
\mathrm{d} \text { with } 1975- \\
\mathrm{s} \text {, an indicato } \\
5 \text {, seven relig } \\
1 \text { by health ins } \\
\text { residence is } \mathrm{x} \\
\mathrm{p}<0.01, * * \mathrm{p}\end{array}$ & $\begin{array}{l}\text { for whether } \\
\text { ion fixed effec } \\
\text { urance. Geogi } \\
\text { rban. Health } \mathrm{f} \\
<0.05,{ }^{*}<0.1\end{array}$ & $\begin{array}{l}6 \text { (NFHS-4) } \\
\text { ormalized by } \\
\text { he child is ty } \\
\text { ts, four caste } \\
\text { aphic control } \\
\text { acility contro }\end{array}$ & $\begin{array}{l}\text { The unit of } \\
\text { the sterilizat } \\
\text { vin, and birtl } \\
\text { fixed effects } \\
\text { s include alt } \\
\text { ls include ho }\end{array}$ & $\begin{array}{l}\text { observation } \\
\text { order of th } \\
20 \text { educatic } \\
\text { ude of the c } \\
\text { spital per } 10\end{array}$ & $\begin{array}{l}\mathrm{n} \text { of the moth } \\
\text { luster in mete } \\
00 \text { populatio }\end{array}$ & $\begin{array}{l}6 \text { at the state } \\
\text { ehold contro } \\
\text { her fixed effe } \\
\text { ers, altitude s } \\
\text { n and doctor }\end{array}$ & $\begin{array}{l}\text { months. Ex } \\
\text { level. Indivi } \\
\text { ls include as } \\
\text { cts, four hou } \\
\text { quared, state } \\
\text { s per } 1000 \mathrm{p}\end{array}$ & $\begin{array}{l}\text { cess Steriliz } \\
\text { lual controls } \\
\text { e and sex o } \\
\text { sehold weal } \\
\text {-level popul } \\
\text { pulation at }\end{array}$ & $\begin{array}{l}\text { tion measur } \\
\text { are for a gen } \\
\text { the househo } \\
\text { index fixed } \\
\text { ion density } \\
\text { he state leve }\end{array}$ & $\begin{array}{l}\text { the numbe } \\
\text { ler indicator } \\
\mathrm{d} \text { head, hou } \\
\text { ffects, and } \\
\text { er square kil } \\
\text { Robust stan }\end{array}$ & $\begin{array}{l}r \text { of excess } \\
\text { variable of } \\
\text { ehold size, } \\
n \text { indicator } \\
\text { ometers (in } \\
\text { dard errors }\end{array}$ \\
\hline
\end{tabular}


Table E3: Alternative Measures of Force Sterilization Policy - Male Sterilization

\begin{tabular}{|c|c|c|c|c|c|c|c|c|c|c|c|c|c|}
\hline Dependent variables: & $\begin{array}{c}\text { Hepatitis } 0 \\
(1)\end{array}$ & $\begin{array}{c}\text { Hepatitis } 1 \\
(2) \\
\end{array}$ & $\begin{array}{c}\text { Hepatitis } 2 \\
(3) \\
\end{array}$ & $\begin{array}{c}\text { Hepatitis } 3 \\
(4) \\
\end{array}$ & $\begin{array}{c}\mathrm{BCG} \\
(5) \\
\end{array}$ & $\begin{array}{c}\text { DPT } 1 \\
(6) \\
\end{array}$ & $\begin{array}{c}\text { DPT } 2 \\
(7) \\
\end{array}$ & $\begin{array}{c}\text { DPT } 3 \\
(8) \\
\end{array}$ & $\begin{array}{c}\text { Polio } 0 \\
(9)\end{array}$ & $\begin{array}{c}\text { Polio } 1 \\
(10) \\
\end{array}$ & $\begin{array}{l}\text { Polio } 2 \\
(11) \\
\end{array}$ & $\begin{array}{l}\text { Polio } 3 \\
(12) \\
\end{array}$ & $\begin{array}{c}\text { Measles } \\
(13)\end{array}$ \\
\hline \multirow{2}{*}{$\begin{array}{l}\text { Excess Male Sterilization } \\
\text { (Vasectomy) }\end{array}$} & $-0.0136^{*}$ & -0.00511 & -0.00559 & $-0.0119^{*}$ & -0.00216 & -0.00195 & -0.00366 & -0.00724 & $-0.0156^{* *}$ & -0.00246 & -0.00520 & -0.00434 & 0.00114 \\
\hline & $(0.00709)$ & $(0.00517)$ & $(0.00585)$ & $(0.00694)$ & $(0.00224)$ & $(0.00278)$ & $(0.00369)$ & $(0.00505)$ & $(0.00653)$ & $(0.00244)$ & $(0.00382)$ & $(0.00425)$ & $(0.00400)$ \\
\hline Individual Controls & YES & YES & YES & YES & YES & YES & YES & YES & YES & YES & YES & YES & YES \\
\hline Household Controls & YES & YES & YES & YES & YES & YES & YES & YES & YES & YES & YES & YES & YES \\
\hline Geographic Controls & YES & YES & YES & YES & YES & YES & YES & YES & YES & YES & YES & YES & YES \\
\hline Health Facility Controls & YES & YES & YES & YES & YES & YES & YES & YES & YES & YES & YES & YES & YES \\
\hline Observations & 228,537 & 228,537 & 228,537 & 228,537 & 231,946 & 231,078 & 231,078 & 231,078 & 231,929 & 231,929 & 231,929 & 231,929 & 230,575 \\
\hline $\begin{array}{l}\text { Mean of Dependent } \\
\text { Variable }\end{array}$ & 0.622 & 0.761 & 0.697 & 0.526 & 0.897 & 0.851 & 0.795 & 0.713 & 0.760 & 0.858 & 0.795 & 0.642 & 0.704 \\
\hline
\end{tabular}

Notes: Data are from India's National Family and Health Survey 2015-16 (NFHS-4). The unit of observation is a child below the age of 5. Excess Male Sterilization (Vasectomy) measures the number of excess by year of birth fied effects, an indicator for whether the child is twin, and bith order of the child Housen by

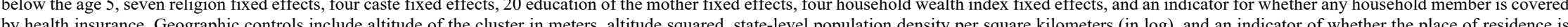
by healh in urban. Health facility controls include hospital per 1000 population and doctors per 1000 population at the state level. Robust standard errors in parentheses clustered at the state level. $* * * \mathrm{p}<0.01, * * \mathrm{p}<0.05, *$ $\mathrm{p}<0.1$ 


\section{Section F: Mechanisms and Robustness}

This section presents the robustness results to the mechanism reported in Section 6. In Table F1, we present the robustness results to Table 5, considering excess male sterilization (vasectomy) as an alternative measure of forced sterilization policy. In Table F2, we present the results of Figure 6 in Table format. In Table F3, we present the robustness results to Figure 6, considering excess male sterilization (vasectomy) as an alternative measure of forced sterilization policy. In Table F4, we present the estimates indexing the reasons for non-institutional delivery. In Table F5, we present the robustness results to Table 6, considering excess male sterilization (vasectomy) as an alternative measure of forced sterilization policy.

Table F1: Robustness to Non-institutional Delivery Using Alternative Measures of Force Sterilization Policy - Male Sterilization

\begin{tabular}{lccccc}
\hline \hline & $(1)$ & \multicolumn{3}{c}{ Dependent variable: Non-institutional Delivery } & $(4)$ \\
& & & $(3)$ & $(4)$ & $(5)$ \\
\hline $\begin{array}{l}\text { Excess Male Sterilization } \\
\text { (Vasectomy) }\end{array}$ & $0.0255^{* *}$ & $0.0191^{* *}$ & $0.0125^{* *}$ & $0.0124^{* * *}$ & $0.0151^{* * *}$ \\
& $(0.0109)$ & $(0.00891)$ & $(0.00502)$ & $(0.00447)$ & $(0.00514)$ \\
& NO & YES & YES & YES & YES \\
Individual Controls & NO & NO & YES & YES & YES \\
Household Controls & NO & NO & NO & YES & YES \\
$\begin{array}{l}\text { Geographic Controls } \\
\text { Health Facility Controls }\end{array}$ & NO & NO & NO & NO & YES \\
$\begin{array}{l}\text { Observations } \\
\text { Mean of Dependent Variable }\end{array}$ & 242,328 & 242,328 & 232,943 & 232,481 & 232,481 \\
\hline
\end{tabular}

Notes: Data are from India's National Family and Health Survey 2015-16 (NFHS-4). The unit of observation is a child below the age of 5. Non-institutional Delivery is an indicator variable for a child born at home in the NFHS-4 data. Excess Male Sterilization (Vasectomy) measures the number of excess vasectomies performed in 1976-77 (compared with 1975-76 numbers) normalized by the vasectomy performed in 1975-76 at the state level. Individual controls are for a gender indicator variable of the child, month by year of birth fixed effects, an indicator for whether the child is twin, and birth order of the child. Household controls include age and sex of the household head, household size, number of household members below the age 5 , seven religion fixed effects, four caste fixed effects, 20 education of the mother fixed effects, four household wealth index fixed effects, and an indicator for whether any household member is covered by health insurance. Geographic controls include altitude of the cluster in meters, altitude squared, state-level population density per square kilometers (in log), and an indicator of whether the place of residence is urban. Health facility controls include hospital per 1000 population and doctors per 1000 population at the state level. Robust standard errors in parentheses clustered at the state level. ${ }^{* * *} \mathrm{p}<0.01,{ }^{* *} \mathrm{p}<0.05,{ }^{*} \mathrm{p}<0.1$ 
Table F2: Mechanism - Reasons for Non-Institutional Delivery (Tabular format)

\begin{tabular}{|c|c|c|c|c|c|c|c|c|c|}
\hline \multirow[t]{3}{*}{ Dependent variables: } & $\begin{array}{l}\text { Cost too } \\
\text { much }\end{array}$ & $\begin{array}{c}\text { Facility not } \\
\text { open }\end{array}$ & $\begin{array}{l}\text { Too far/ no } \\
\text { transportation }\end{array}$ & $\begin{array}{l}\text { No female } \\
\text { provider at } \\
\text { facility }\end{array}$ & $\begin{array}{l}\text { Don't trust } \\
\text { facility/ poor } \\
\text { quality service }\end{array}$ & $\begin{array}{l}\text { Husband/ } \\
\text { family did not } \\
\text { allow }\end{array}$ & $\begin{array}{c}\text { Not } \\
\text { necessary }\end{array}$ & Not customary & Other \\
\hline & \multicolumn{4}{|c|}{ Supply Side Factors } & \multicolumn{4}{|c|}{ Demand Side Factors } & \\
\hline & $(1)$ & $(2)$ & $(3)$ & $(4)$ & $(5)$ & $(6)$ & $(7)$ & $(8)$ & $(9)$ \\
\hline Excess Sterilization & $\begin{array}{l}-0.000113 \\
(0.00106)\end{array}$ & $\begin{array}{c}0.000643 \\
(0.000417)\end{array}$ & $\begin{array}{l}0.000687 \\
(0.00119)\end{array}$ & $\begin{array}{c}0.000504^{* *} \\
(0.000240)\end{array}$ & $\begin{array}{c}0.00138^{* * *} \\
(0.000361)\end{array}$ & $\begin{array}{c}0.00277 * * * \\
(0.00103)\end{array}$ & $\begin{array}{c}0.00582 * * \\
(0.00270)\end{array}$ & $\begin{array}{c}0.000774 * * * \\
(0.000238)\end{array}$ & $\begin{array}{c}0.00338 * * * \\
(0.000827)\end{array}$ \\
\hline Individual Controls & YES & YES & YES & YES & YES & YES & YES & YES & YES \\
\hline Household Controls & YES & YES & YES & YES & YES & YES & YES & YES & YES \\
\hline Geographic Controls & YES & YES & YES & YES & YES & YES & YES & YES & YES \\
\hline $\begin{array}{l}\text { Health Facility } \\
\text { Controls }\end{array}$ & YES & YES & YES & YES & YES & YES & YES & YES & YES \\
\hline Observations & 232,481 & 232,481 & 232,481 & 232,481 & 232,481 & 232,481 & 232,481 & 232,481 & 232,481 \\
\hline $\begin{array}{l}\text { Mean of Dependent } \\
\text { Variable }\end{array}$ & 0.0216 & 0.0135 & 0.0249 & 0.00489 & 0.00836 & 0.0248 & 0.0542 & 0.00518 & 0.0121 \\
\hline
\end{tabular}

Notes: Data are from India's National Family and Health Survey 2015-16 (NFHS-4). The unit of observation is a child below the age of 5. Excess Sterilization measures the number of excess sterilizations performed in 1976-77 (compared with 1975-76 numbers) normalized by the sterilization performed in 1975-76 at the state level. Individual controls are for a gender indicator variable of the child, month by year of birth fixed effects, an indicator for whether the child is twin, and birth order of the child. Household controls include age and sex of the household head, household size, number of household members below the age 5, seven religion fixed effects, four caste fixed effects, 20 education of the mother fixed effects, four household wealth index fixed effects, and an indicator for whether any household member is covered by health insurance. Geographic controls include altitude of the cluster in meters, altitude squared, state-level population density per square kilometers (in log), and an indicator of whether the place of residence is urban. Health facility controls include hospital per 1000 population and doctors per 1000 population at the state level. Robust standard errors in parentheses clustered at the state level. $* * *$ p $<0.01, * *$ $\mathrm{p}<0.05, * \mathrm{p}<0.1$ 
Table F3: Robustness to Reasons for Non-institutional Delivery Using Alternative Measures of Force Sterilization Policy - Male Sterilization

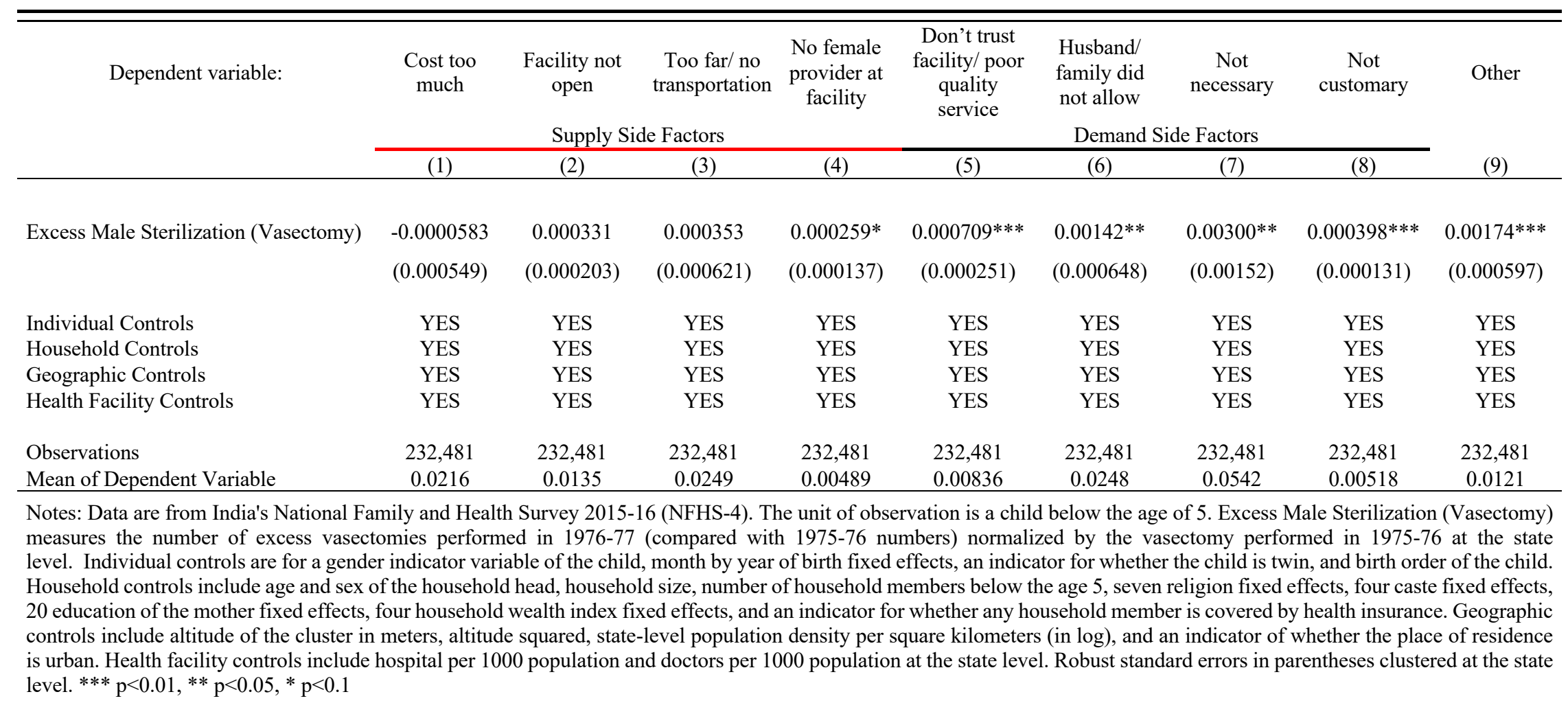


medRxiv preprint doi: https://doi.org/10.1101/2021.01.21.21250216; this version posted August 11, 2021. The copyright holder for this preprint (which was not certified by peer review) is the author/funder, who has granted medRxiv a license to display the preprint in perpetuity.

It is made available under a CC-BY-NC-ND 4.0 International license .

Table F4: Robustness to Indexing the Reasons for Non-institutional Delivery

\begin{tabular}{lcc}
\hline Dependent variables: & $\begin{array}{c}\text { Supply Side } \\
(1)\end{array}$ & $\begin{array}{c}\text { Demand Side } \\
(2)\end{array}$ \\
\hline Excess Sterilization & 0.00194 & $0.00995^{* * *}$ \\
& $(0.00167)$ & $(0.00357)$ \\
& & \\
Individual Controls & YES & YES \\
Household Controls & YES & YES \\
Geographic Controls & YES & YES \\
Health Facility Controls & YES & YES \\
& & \\
Observations & 232,481 & 232,481 \\
Mean of Dependent Variable & 0.0548 & 0.0855 \\
\hline
\end{tabular}

Notes: Data are from India's National Family and Health Survey 2015-16 (NFHS-4). The unit of observation is a child below the age of 5. Supply Side is an index that include Cost too much, Facility not open, Too far/ no transport, and No female provider. Demand Side is an index that include Do not trust facility/ poor service, Husband/family did not allow, Not necessary, and Not customary. Excess Sterilization measures the number of excess sterilizations performed in 1976-77 (compared with 1975-76 numbers) normalized by the sterilization performed in 1975-76 at the state level. Individual controls are for a gender indicator variable of the child, month by year of birth fixed effects, an indicator for whether the child is twin, and birth order of the child. Household controls include age and sex of the household head, household size, number of household members below the age 5, seven religion fixed effects, four caste fixed effects, 20 education of the mother fixed effects, four household wealth index fixed effects, and an indicator for whether any household member is covered by health insurance. Geographic controls include altitude of the cluster in meters, altitude squared, state-level population density per square kilometers (in $\log$ ), and an indicator of whether the place of residence is urban. Health facility controls include hospital per 1000 population and doctors per 1000 population at the state level. Robust standard errors in parentheses clustered at the state level. $* * * \mathrm{p}<0.01, * * \mathrm{p}<0.05, * \mathrm{p}<0.1$ 
medRxiv preprint doi: https://doi.org/10.1101/2021.01.21.21250216; this version posted August 11, 2021. The copyright holder for this preprint

(which was not certified by peer review) is the author/funder, who has granted medRxiv a license to display the preprint in perpetuity.

It is made available under a CC-BY-NC-ND 4.0 International license .

Table F5: Robustness to Information Provision through Antenatal Care (ANC) Using Alternative

$$
\text { Measures of Force Sterilization Policy - Male Sterilization }
$$

\begin{tabular}{lcc}
\hline \hline Dependent variables: & $\begin{array}{c}\text { Received Any } \\
\text { Antenatal Care } \\
(1)\end{array}$ & $\begin{array}{c}\text { Number of } \\
\text { Visits } \\
(2)\end{array}$ \\
\hline Excess Male Sterilization (Vasectomy) & $-0.0101^{* *}$ & $-0.649^{* * *}$ \\
& $(0.00505)$ & $(0.230)$ \\
Individual Controls & YES & YES \\
Household Controls & YES & YES \\
Geographic Controls & YES & YES \\
Health Facility Controls & YES & YES \\
Observations & 177,040 & 146,167 \\
Mean of Dependent Variable & 0.832 & 5.685 \\
\hline
\end{tabular}

Notes: Data are from India's National Family and Health Survey 2015-16 (NFHS-4). The unit of observation is a mother. Received Antenatal Care is an indicator variable for mothers who received antenatal care in the last pregnancy in the NFHS-4 data. Number of Visits measures the number of times the mother received antenatal care conditional on receiving any antenatal care in the last pregnancy. Excess Male Sterilization (Vasectomy) measures the number of excess vasectomies performed in 1976-77 (compared with 1975-76 numbers) normalized by the vasectomy performed in 1975-76 at the state level. Individual controls are for a gender indicator variable of the child, month by year of birth fixed effects, an indicator for whether the child is twin, and birth order of the child. Household controls include age and sex of the household head, household size, number of household members below the age 5 , seven religion fixed effects, four caste fixed effects, 20 education of the mother fixed effects, four household wealth index fixed effects, and an indicator for whether any household member is covered by health insurance. Geographic controls include altitude of the cluster in meters, altitude squared, state-level population density per square kilometers (in $\log$ ), and an indicator of whether the place of residence is urban. Health facility controls include hospital per 1000 population and doctors per 1000 population at the state level. Robust standard errors in parentheses clustered at the state level. $* * * \mathrm{p}<0.01, * * \mathrm{p}<0.05,{ }^{*} \mathrm{p}<0.1$ 


\section{$\underline{\text { Section G: Robustness to Consequence }}$}

\section{Table G1: Robustness to Consequence Using Alternative Measures of Force Sterilization Policy - Male Sterilization}

\begin{tabular}{|c|c|c|c|c|c|}
\hline & \multicolumn{5}{|c|}{ Dependent variable: Child is not Alive } \\
\hline & (1) & $(2)$ & $(3)$ & $(4)$ & $(5)$ \\
\hline \multirow{2}{*}{$\begin{array}{l}\text { Excess Male Sterilization } \\
\text { (Vasectomy) }\end{array}$} & $0.00470 * * *$ & $0.00432 * * *$ & $0.00394 * * *$ & $0.00395 * * *$ & $0.00407 * * *$ \\
\hline & $(0.00161)$ & $(0.00146)$ & $(0.00121)$ & $(0.00116)$ & $(0.00140)$ \\
\hline Baseline Controls & NO & YES & YES & YES & YES \\
\hline Household Controls & NO & NO & YES & YES & YES \\
\hline Geographic Controls & NO & $\mathrm{NO}$ & NO & YES & YES \\
\hline Health Facility Controls & $\mathrm{NO}$ & $\mathrm{NO}$ & $\mathrm{NO}$ & NO & YES \\
\hline \multirow{2}{*}{$\begin{array}{l}\text { Observations } \\
\text { Mean of dependent } \\
\text { variable }\end{array}$} & 254,015 & 254,015 & 244,265 & 243,781 & 243,781 \\
\hline & 0.0441 & 0.0441 & 0.0446 & 0.0445 & 0.0445 \\
\hline \multicolumn{6}{|c|}{$\begin{array}{l}\text { Notes: Data are from India's National Family and Health Survey 2015-16 (NFHS-4). The unit of observation is a } \\
\text { child below the age of } 5 \text { including who are not alive. Excess Male Sterilization (Vasectomy) measures the number } \\
\text { of excess vasectomies performed in 1976-77 (compared with 1975-76 numbers) normalized by the vasectomy } \\
\text { performed in } 1975-76 \text { at the state level. Individual controls are for a gender indicator variable of the child, month } \\
\text { by year of birth fixed effects, an indicator for whether the child is twin, and birth order of the child. Household } \\
\text { controls include age and sex of the household head, household size, number of household members below the } \\
\text { age 5, seven religion fixed effects, four caste fixed effects, } 20 \text { education of the mother fixed effects, four } \\
\text { household wealth index fixed effects, and an indicator for whether any household member is covered by health } \\
\text { insurance. Geographic controls include altitude of the cluster in meters, altitude squared, state-level population } \\
\text { density per square kilometers (in log), and an indicator of whether the place of residence is urban. Health facility } \\
\text { controls include hospital per } 1000 \text { population and doctors per } 1000 \text { population at the state level. Robust standard } \\
\text { errors in parentheses clustered at the state level. } * * * p<0.01, * * p<0.05, * p<0.1\end{array}$} \\
\hline
\end{tabular}

